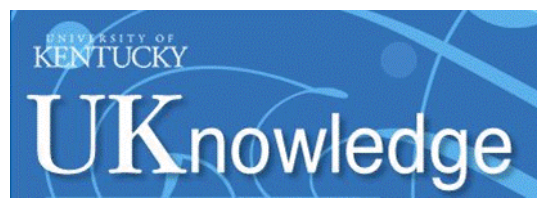

University of Kentucky

UKnowledge

Pharmacology and Nutritional Sciences Faculty

Publications

Pharmacology and Nutritional Sciences

$10-2017$

\title{
Adipose Tissue as a Site of Toxin Accumulation
}

\author{
Erin Jackson \\ University of Kentucky \\ Robin C. Shoemaker \\ University of Kentucky, robin.shoemaker@uky.edu \\ Nika Larian \\ University of Kentucky, nika.larian@uky.edu \\ Lisa A. Cassis \\ University of Kentucky, Icassis@uky.edu
}

Follow this and additional works at: https://uknowledge.uky.edu/pharmacol_facpub

Part of the Endocrinology, Diabetes, and Metabolism Commons, Medical Nutrition Commons, Pharmacology, Toxicology and Environmental Health Commons, and the Physiology Commons

Right click to open a feedback form in a new tab to let us know how this document benefits you.

\section{Repository Citation}

Jackson, Erin; Shoemaker, Robin C.; Larian, Nika; and Cassis, Lisa A., "Adipose Tissue as a Site of Toxin Accumulation" (2017). Pharmacology and Nutritional Sciences Faculty Publications. 78.

https://uknowledge.uky.edu/pharmacol_facpub/78

This Article is brought to you for free and open access by the Pharmacology and Nutritional Sciences at UKnowledge. It has been accepted for inclusion in Pharmacology and Nutritional Sciences Faculty Publications by an authorized administrator of UKnowledge. For more information, please contact UKnowledge@lsv.uky.edu. 


\section{Adipose Tissue as a Site of Toxin Accumulation}

Digital Object Identifier (DOI)

https://doi.org/10.1002/cphy.c160038

Notes/Citation Information

Published in Comprehensive Physiology, v. 7, issue 4, p. 1085-1135.

Copyright @ 2017 American Physiological Society. All rights reserved.

The copyright holder has granted the permission for posting the article here.

The document available for download is the authors' post-peer-review final draft of the article.

A corrigendum to this article can be found at https://doi.org/10.1002/cphy.cv08i03corr.

This article is available at UKnowledge: https://uknowledge.uky.edu/pharmacol_facpub/78 


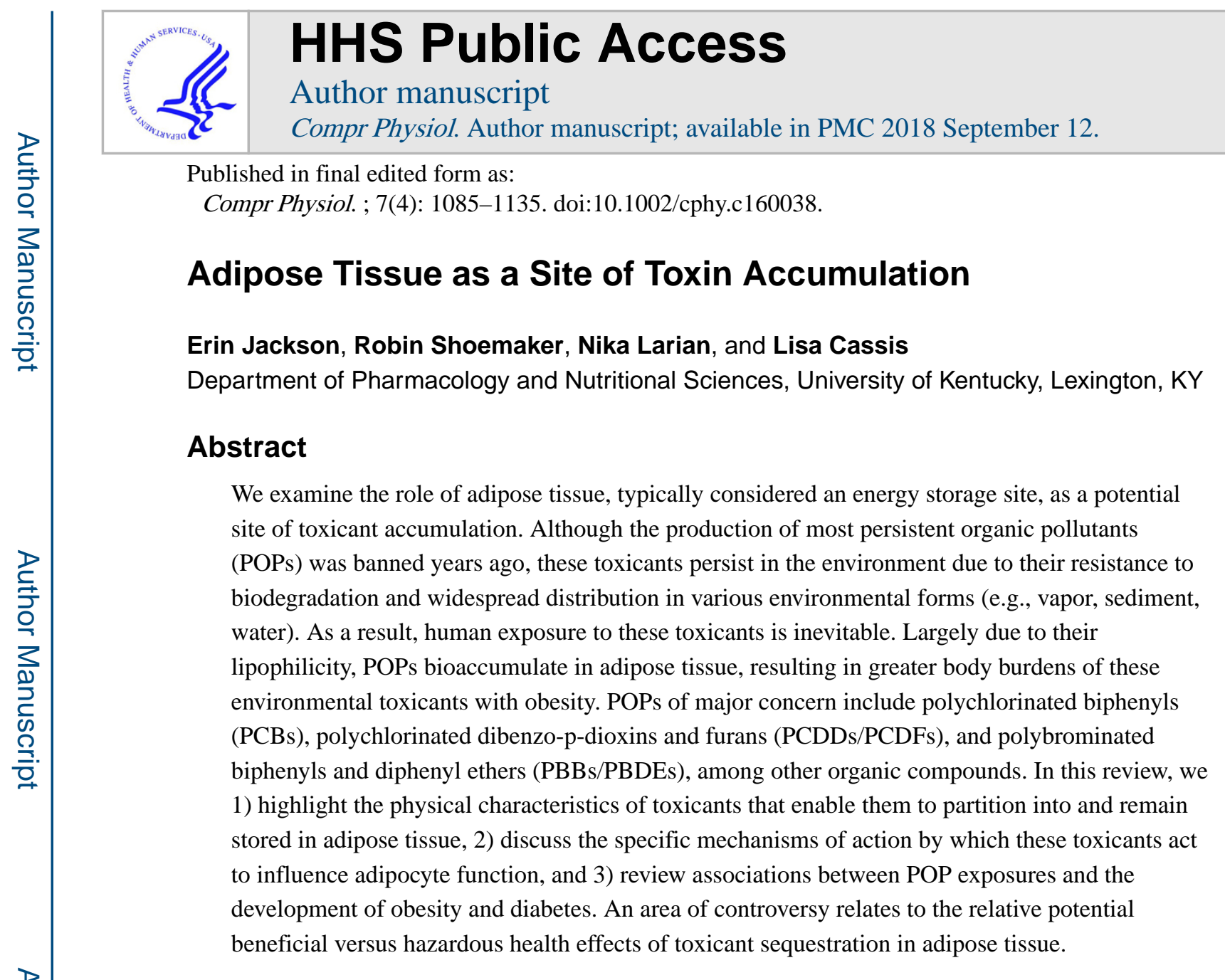

\section{Introduction}

As the name implies, POPs are organic lipophilic compounds that are resistant to environmental degradation, exhibit considerable stability, and persist in the environment. Due to their low water solubility, POPs can present as vapors in the atmosphere or strongly bind to particulate matter in sediments, where the sediment may serve as a reservoir, removing the POPs from circulation (18). If disturbed, however, the POPs may be released from the sediment and travel far from their origin before being re-deposited. One hallmark characteristic of POPs is their ability to move up the food chain and increase in concentration, or biomagnify, subsequently resulting in widespread environmental and human exposure (18). This is largely due to the high degrees of halogenation, which allows them to resist degradation by metabolizing enzymes. The bioaccumulation potential of these compounds can allow them to biomagnify to potentially dangerous levels (193) (245).

To address the global concern of environmental pollutants, 90 countries signed a United Nations treaty in 2001, known as the Stockholm Convention (18). The intention of the Convention was to severely limit, but preferentially eliminate, the widespread production and use of POPs. Recognizing the potentially toxic effects of POPs on human and environmental health, a preliminary list of chemicals known as the "dirty dozen" was established (18). This original list of 12 key POPs included aldrin, chlordane, dichlorodiphenyltrichloroethane (DDT), dieldrin, endrin, heptachlor, hexachlorobenzene, 
mirex, toxaphene, polychlorinated biphenyls (PCBs), polychlorinated dibenzo-p-dioxins (dioxins), and polychlorinated dibenzofurans (furans) (18). Since then, this list has expanded to include additional compounds, such as polycyclic aromatic hydrocarbons (PAHs), brominated flame retardants (BFRs), and other compounds that have proven particularly harmful and toxic to humans and animals (see Table 1 for a full list of abbreviations that will be used throughout the text). The primary route of human exposure to POPs is via food contamination, where fatty foods (e.g. meat, fish, and dairy) are important vectors for many classes of POPs, including PCBs, polybrominated flame retardants, dioxins and furans (PCDDs/PCDFs), and other organochlorines (Table 2).

When considering the toxicity of POPs, it is important to discuss their relationship with adipose tissue (AT), a significant site of toxicant bioaccumulation. AT is a connective tissue that is primarily comprised of white or brown adipocytes, but also contains several other cell types. White adipocytes are the most common type of fat cell, serving as a storage depot for lipids that are released upon need as an energy source. By comparison, brown adipocytes, which are much less prevalent in adults, are enriched with specialized mitochondria that mobilize lipid to produce heat for maintenance of body temperature (347). Of the two primary types of adipocytes, white adipocytes, with a large unilocular lipid droplet, are the prominent storage site of lipophilic POPs. It has been suggested that AT plays a major role in the storage and overall toxicokinetics of hydrophobic xenobiotic POPs (202) (203) (213). In addition, the physical properties that enable certain toxins/toxicants to partition into lipid are important in determining the extent of AT POP sequestration. The octanol:water partition coefficient, for example, offers insight into a toxicant's ability to partition between water and organic matter, and provides a clearer understanding of a toxicant's potential biological uptake, accumulation, and storage in AT (213).

The collection and storage of POPs in fatty tissue can have both positive and negative consequences. One beneficial aspect of POP sequestration in AT is that the toxicant concentration in blood is decreased, limiting POP availability to other cells and tissues where they may have hazardous effects (213). In this manner, POP sequestration in AT lipids appears protective against the harsh effects of lipophilic toxicants (24) (27) (137) (399) (154) (123). On the contrary, bioaccumulation of POPs in expanded AT of obese subjects results in a significantly increased body burden (213). The tonic release of these chemicals into the systemic circulation, especially during periods of weight loss (96) (105) (202) (240) (213) (283), can pose tremendous threats on overall human health (202) (154) (316) (38) (39) (231). We review data on accumulation of specific POPs in AT, their mechanism of action, and influence on diseases associated with dysregulation of AT function.

\section{Physico-chemical properties and lipids influence AT POP bioaccumulation}

The dynamics of contaminant accumulation in and release from AT depends on their physicchemical properties. The partition coefficient has proven to be a major parameter governing the uptake of lipophilic toxicants into adipocytes. However, even within a toxicant class, structural determinants dictate physico-chemical properties that determine AT accumulation. For example, different PCB congeners can display distinct uptake and storage dynamics into adipocytes (54) (250) (249). One study compared the accumulation potential in AT of three 
PCB congeners: PCB $-28,-153$, and -118 based on each of the congeners physicochemical features. Results indicated that the dynamics of accumulation varied between the congeners due to molecular size, molecular volume, and lipophilicity (54). Specifically, the degree of halogenation, or number and position of chlorine substituents on the PCBs, influenced their uptake and accumulation in adipocytes. PCB-28 entered adipocytes more rapidly than the other two congeners likely due to its smaller molecular weight, size, and lipophilicity, while PCBs -153 and -118 remained trapped in the lipophilic cell membrane and diffused more slowly into the intracellular, hydrophobic cytoplasm of the adipocyte (54).

The lipophilicity of a compound depends on its chemical structure, where bigger, more complex and halogenated compounds are typically more lipophilic and resistant to biodegradation (206). As early as the 1900s, researchers tested for lipophilicity by studying the uptake of nonpolar compounds using organic solvents, like octanol, as a surrogate for the organic matter present in organisms (345). Although not identical, the extent of chemical uptake from the water into the organic phase is proportional to what is expected and observed in organisms (345). The octanol-water partition coefficient $\left(\mathrm{K}_{\mathrm{ow}}\right)$ is defined by the following equation: $\mathrm{K}_{\mathrm{ow}}=\mathrm{Coctanol} / \mathrm{Cwater}$, where Coctanol is the molar concentration of the compound in the octanol phase, and Cwater is the molar concentration of the compound in the aqueous phase when the system is at equilibrium (345). The adipose-serum partition coefficient determines the extent to which a chemical may accumulate in adipose (319); it is a ratio of the concentration of a chemical in adipose to serum at equilibrium. Typically, the distribution of xenobiotics into AT is dependent on a number of pharmacokinetic factors including tissue volume and blood flow (232). The standard approach assumes that the tissue is "flow limited," which means that the venous blood leaving the organ is at equilibrium with the "well-stirred" tissue compartment (232). While this approach has proven valid for the distribution of various xenobiotics into tissues and organs, there are a number of chemicals for which this flow limited model has proven invalid, including highly lipophilic POPs (421) (190) (208) (232). These chemicals, along with other organic compounds, act according to a "diffusion-limited" model, which states that diffusion limitation is proportional to the octanol-water partition coefficient $\left(\mathrm{K}_{\mathrm{ow}}\right)$ of a chemical (232).

Ultimately, diffusion limitation increases as $\mathrm{K}_{\mathrm{ow}}$ increases. In support of the studies by Oberg et al. (294) who simultaneously measured PCB concentrations in rat plasma and adipose tissue, Levitt (232) found that hexachlorobenzene (HCB), hexabromobenzene, 2,3,7,8-tetrachlorodibenzo-p-dioxin (TCDD), and tetrabrominated dinenzo-p-dioxin (TBDD) have a "similar increase in diffusion limitation with increasing $\mathrm{K}_{\mathrm{ow}}$." Specifically, results of the study showed that the "apparent" rat adipose perfusion rate was smaller for a PCB $(0.005 \mathrm{~kg} / \mathrm{min} / \mathrm{kg})$ with a $\log \mathrm{K}_{\text {ow }}$ greater than 7 , while significantly larger $(0.2$ $\mathrm{kg} / \mathrm{min} / \mathrm{kg}$ ) for chemicals with $\log \mathrm{K}_{\mathrm{ow}}$ less than 5 (232). Collectively, these studies support the notion that at steady-state conditions, the $\log \mathrm{K}_{\mathrm{ow}}$, a measure of lipophilicity, can help predict the likelihood of a chemical to diffuse and accumulate into AT and contribute to steady-state body burdens. Table 3 provides an overview of the structures and partition coefficients of numerous POPs. 
Lipids are generally the primary components of any tissue that determine the movement, distribution, and sequestration of hydrophobic compounds, and play a vital role in toxicant accumulation in tissues (41). The bioaccumulation potential of a toxicant can vary among different lipid classes. For example, phospholipids exhibit moderate polarity, while triglycerides and free fatty acids display neutral polarity, which can influence their tendency to accumulate toxicants (1). Despite the large number of cell types in AT (i.e. preadipocytes, fibroblasts, macrophages, etc.), storage of POPs is believed to primarily occur in adipocytes (54) whose cytoplasm is composed mainly of triglyceride droplets (341). There are reports indicating that TCDD and DDT are transported out of the gut into the triglyceride component of chylomicrons, which are responsible for delivering lipids absorbed from the intestine to AT (416) (205). Another study demonstrated that the extent of PCB accumulation in different adipocyte models directly correlated to the amount of cellular triglycerides (54). However, due to the high cost of analyzing toxicants in different lipid components, toxicants are generally reported as a measure of total lipids in tissues (54).

It appears that the type of fat storage may also contribute to AT toxicant accumulation. There are two major areas where AT deposits: 1) visceral AT (vAT), which surrounds internal organs and is generally considered to contribute to obesity-related diseases (275) (196) (257), and 2) subcutaneous AT (scAT), located beneath the skin. These AT locations can display unique structural features and properties that may influence the kinetics of toxicants. Although one study found no significant difference in POP accumulation between visceral versus subcutaneous AT (256), several studies found that visceral AT contained higher POP concentrations than subcutaneous AT (316). In an obese population in Portugal, endrin and endosulfan I and II were detected in more visceral compared to subcutaneous AT samples (316). Moreover, the total concentration of POPs was significantly higher ( $\mathrm{p}<0.001)$ in vAT $(213.9+204.2 \mathrm{ng} / \mathrm{g}$ fat $)$ versus scAT $(155.1+147.4 \mathrm{ng} / \mathrm{g}$ fat $)(316)$. Although a greater percentage of the population had detectable levels of endosulfans I and II and methoxychlor in their visceral compared to subcutaneous AT, higher concentrations of each toxicant were detected in subcutaneous AT (316). Similarly, average concentrations of aldrin and median concentrations of lindane were higher in subcutaneous than visceral AT (316).

It is worth noting that a possible explanation for the varying concentrations of POPs in different types of AT may depend on the individual exposed to the toxicant and toxicant exposure duration (434). Orban et al. (303) noted that the effect of age was also a significant factor for the detection of nine PCDDs/PCDFs in AT, while no significant differences were associated with sex or race.

Numerous toxicants have been detected in different AT samples from various populations (Table 4). In humans, two of the most predominant chlordane-related contaminants (transnonachlor and oxychlordane) were detected in breast milk and AT (50). In addition, levels of PAHs, including anthracene, pyrene, benzo[e]pyrene, benzo[k]fluoranthene, benzo[a]pyrene, and benzo[g,h,i]perylene, were detected in AT samples in the range of 11 to 2,700 ng/g tissue (293). PAH refers to a ubiquitous group of over 100 environmental POPs that are composed of multiple aromatic rings containing only carbon and hydrogen. Total concentrations of PAHs in AT from Korean women ranged from 15 to $361 \mathrm{ng} / \mathrm{g}$ lipid (277), and levels of dioxin-like PCBs ranged from 4.1 to $125 \mathrm{ng} / \mathrm{g}$ lipid in a Chinese population 
(353). Mean levels of chlorobenzenes, including pentachlorobenzene (PeCB), in human milk and adipose tissue samples ranged from undetectable to $146 \mathrm{ng} / \mathrm{g}$ (178). Some of the highest levels of polybrominated diphenyl ethers (PBDEs) in AT were found in a New York population, with concentrations ranging from 17 to an astounding 9,630 ng/g lipid weight (183).

Blood levels of POPs (as shown in Table 4) are commonly used to assess point exposures (33) (279) (55) (363) (416) (309) (319). Hydrophobic toxicants in blood often bind to lipoproteins and proteins. Many PCBs and other organochlorine pesticides found in blood, for example, are associated with the protein fraction and all major lipoprotein compartments, including very low density lipoprotein (VLDL), low density lipoprotein (LDL), and high density lipoprotein (HDL) (416). Aldrin and dieldrin bind to VLDL and LDL to distribute preferentially to fat, while chlordecone and mirex preferentially bind albumin and HDL (363), and pentachlorophenol (PCP) strongly binds to plasma proteins (55). Furthermore, Ljunggren et al. (243) found that POP concentrations in LDL/VLDL were more associated with cancer, while POPs in HDL were more associated with cardiovascular disease.

Although most PCDD/PCDF congeners are found in lipoproteins of blood, liver, and fat tissues (319), the more highly chlorinated congeners (penta-through octa-substituted) do not partition between the lipoprotein and protein fractions of blood (309). In addition, less than $20 \%$ of dichlorodiphenyldichloroethylene (DDE) or DDT was distributed in erythrocytes, but greater than $40 \%$ of dieldrin was detected in these blood cells (279).

Measurements taken in whole blood, serum and/or plasma are minimally invasive, but may add difficulty in comparing toxicant concentrations between blood samples and other tissues. For example, Teixeira et al. (389) reported that plasma levels of aldrin did not reflect levels accumulated in tissues, and Archibeque-Engle et al. (30) found no correlation between levels of 15 of 17 compounds in breast AT compared to serum. Thus, preferential binding of some toxicants to lipoproteins and various other lipid compartments in serum and AT may contribute to reported variance of blood levels versus toxicant concentrations in other tissues (434).

When discussing toxicants in AT, it is important to define the process of bioaccumulation, which refers to the build-up of substances in the body because the substance is not readily metabolized and excreted. Many organic compounds not only resist environmental degradation, but may also bypass liver biotransformation enzymes and diffuse into AT. Highly lipid soluble POPs can disseminate through the food chain by collecting in body fat and biomagnifying, or increasing in concentration as they move from one organism to another. For example, the northern elephant seal is a "marine mammal predator" at the top of the food chain that contains massive concentrations of environmental contaminants that are primarily stored in AT (249) (99) (250) (318) (2). Measurements of bioaccumulation in fish and other aquatic organisms is often reported as the bioconcentration factor (BCF), which is defined as the extent to which a chemical concentration in an aquatic organism exceeds the chemical concentration in surrounding water (206). BCFs also correlate with octanol-water partition coefficients (345). Table 4 summarizes various bioaccumulation studies in aquatic organisms. 
Once sequestered in adipose, toxicants are not released until lipolysis occurs, often through weight loss, diet, and exercise. It has been well documented that throughout episodes of fasting or weight loss, AT serves as a source of PCBs due to lipid mobilization (202) (250) (249). With lipolysis, PCBs and other toxicants are not only released into blood but they also concentrate into remaining AT (72) (202) (250) (249). Although no link has been established, one hypothesis for the "heterogeneous release of PCBs" from AT is that during lipolysis, fatty acids are differentially mobilized from AT and may influence the release of some PCBs versus others (98).

The release of PCBs and other toxicants into systemic circulation can potentially expose an individual to various known hazardous effects. Therefore, measuring chemical contaminants (and/or their metabolites) in adipose and blood samples can provide great insight into overall exposures and body burden, which can strengthen the ability to determine associations between chemical exposures and the development of adverse health effects.

\section{Effects of POPs on AT function}

While epidemiological studies indicate an association between systemic POP concentrations and metabolic diseases (228) (382) (386), mechanisms mediating impairment of metabolism by POPs remain unclear. In addition to the central role that AT plays in maintenance of metabolism and energy homeostasis through storage of excess fuels as fat (lipogenesis) and mobilization of fatty acids for use as fuel (lipolysis), adipocytes secrete a multitude of adipokines that contribute to metabolic regulation and inflammatory responses. In addition, a major role of AT is expansion in response to metabolic excess, which is achieved through both an increase in adipocyte size (hypertrophy) and increased differentiation of preadipocytes to mature adipocytes (adipocyte differentiation). Given the central role of AT in regulation of body weight and metabolism, POP-mediated disruption of AT function may contribute to the development of obesity and related metabolic diseases. A summary of the effects of POPs on AT function, organized by pollutant class, is presented in Table 5, and a summary of the major mechanisms by which POPs are purported to influence AT function is presented in Table 6.

\section{Adipocyte differentiation}

Mechanisms regulating fat accumulation have been a major focus of research given the increased prevalence of obesity and associated health risks. Several studies have characterized the effects of POPs on the differentiation of progenitor cells and/or preadipocytes to mature, lipid-laden adipocytes but findings have been contradictory. Findings are further complicated by use of a variety of models. For example, use of preadipocyte cell lines with restricted potential to differentiate into other cell types (e.g. 3T3-L1 cells) versus use of multi- or pluri-potent stem cells (mesenchymal stem cells or stromal-vascular cells) can influence the experimental outcome. The effects of TCDD and dioxin-like PCBs on adipocyte differentiation have been the most heavily studied. TCDD has consistently been shown to decrease adipocyte differentiation in vitro in 3T3-L1 cells (354) (161) and from stromal vascular cells (56). Further, TCDD (in an aryl hydrocarbon receptor (AhR)-dependent manner) was demonstrated to suppress hormone-induced 
adipogenesis in mouse embryonic fibroblasts that exhibited proliferative expansion, but did not exit the cell cycle when exposed to the toxicant, suggesting that TCDD is an early regulator of adipocyte differentiation (26). However, effects appear to be dose-dependent. Low doses of both TCDD and dioxin-like PBC-77 induced differentiation of 3T3-L1 adipocytes, while high doses had an inhibitory effect (34). These results suggest that the reported effect of TCDD at high doses to induce wasting syndrome (348) may relate to an ability of the toxicant to decrease adipocyte differentiation, while lower exposures may contribute to an obesogenic phenotype. By comparison, studies examining effects of various organochlorine pesticides such as the non-dioxin-like PCB-153 (69), DDE (69) in human preadipocytes, and DDT in 3T3-L1 cells (278) report increased adipocyte differentiation. An ability of low dose POPs to induce adipocyte differentiation are consistent with increased body burden of these toxicants with obesity (332) (333) (104).

In addition to organochlorine pesticides, phthalates have also been associated with increased BMI and waist circumference (WC) in humans (370). Moreover, di(2-ethylhexyl) phthalate (DEHP) or its metabolite mono-(2-ethylhexyl) phthalate (MEHP) increased adipocyte differentiation in 3T3-L1 cells, (142) (115), murine mesenchymal stem cells (44), and in vivo (142) (62). Few human studies have addressed effects of BFRs on obesity and metabolic syndrome; however, adipocyte differentiation was increased by the BFRs PDBE (397) and BDE-47 (185). These findings are supported by a recent study which reported increased body weight of obese mice treated with hexabromocyclododecane (HBCD) (431). Other environmental toxicants (bisphenol A, BPA, bisphenol A diglycidyl ether, BADGE) have also been reported to increase adipocyte differentiation in 3T3-L1 cells (258), in vivo, (433) and in adipose stromal stem cells (297) (67).

\section{Lipid Storage and Mobilization}

Uptake of circulating fatty acids for storage as triglycerides is a major function of AT, with excess lipid accumulation a hallmark of expanded AT mass with obesity. In 3T3-L1 adipocytes, the organochlorine pesticides DDE, oxychlordane, and dieldrin have been reported to increase basal fatty acid uptake (160) and BPA was demonstrated to increase lipid accumulation (32). Administration of PCB-77 to mice resulted in greater body weight and adipocyte hypertrophy (34). Similarly, in utero exposure of mice to BPA (433) or the phthalates DHEP and MEHP increased adult fat mass, lipid accumulation and body weight (142) (373). However, in general, reports of direct effects of POPs to increase lipid accumulation are limited. As discussed below, and summarized in Table 6, it is likely that increases in lipogenesis or fat deposition can be attributed to impaired metabolism through endocrine disrupting effects of POPs.

In contrast, TCDD has been reported to reduce lipid accumulation and/or promote lipid mobilization (235) from adipocytes. This effect of TCDD has been attributed to inhibition of lipoprotein lipase (LPL), a key enzyme in the pathway for adipocyte uptake of fatty acids for storage as triglycerides (302) (195). 


\section{Adipokine secretion}

A major function of AT is the secretion of a wide range of signals and factors termed adipokines. These include inflammatory cytokines (TNF- $a$, interleukins) and chemokines (MCP-1), as well as hormones that participate in body weight regulation and glucose and lipid homeostasis (adiponectin, leptin, resistin) (396). Reduced adiponectin levels (237) and increased resistin levels (177) with obesity are associated with insulin resistance and inflammation (237). Several studies have linked BPA exposure with regulation of AT adipokines. A study in obese children reported an association of urinary BPA concentration with insulin resistance, and incubation of AT explants from these patients with BPA increased gene expression of resistin and decreased gene expression of adiponectin (264). Similarly, incubation of adult AT explants with BPA inhibited adiponectin (166). In contrast, one study reported an increase in leptin and adiponectin expression in 3T3-L1 cells incubated with BPA (385). As BPA was also reported to increase adipocyte differentiation, it is possible that the increase in leptin and adiponectin reflected an increase in the mature adipocyte population. In addition to BPA (404) (32) (433), gene expression and secretion of inflammatory factors from adipocytes has been reported to increase in response to TCDD (195) (235) (34) (292) (203), PCB-77 (34) PCB-126 (203), and DEHP (62). Moreover, infiltration of macrophages into AT, a pathway associated with obesity-induced insulin resistance, has been reported as a result of exposure to DEHP (a phthalate) (62) HBCD (a BFR) (431), and TCDD (415).

\section{Glucose uptake}

Glucose uptake by adipocytes contributes to whole body glucose homeostasis and impaired glucose uptake is associated with insulin resistance. A vast majority of data indicate that POPs impair glucose uptake in adipocytes. Specifically, treatment of adipocytes with TCDD, PCBs, DDT, BFRs, BPA, and PAHs impaired glucose uptake. Exposure of animals to PCBs (38), phthalates (142) (374), BFRs (431), or mixtures of POPs (336) impaired insulin sensitivity. Mechanisms for these effects are not fully understood, but may include reduced AT levels of Glut-4 mRNA or increased expression of inflammatory markers (both AT and circulating levels) associated with impaired glucose uptake or insulin resistance.

\section{Mechanisms of POPs to impair AT function}

1. AhR-AhR is a basic-helix-loop-helix Per-ARNT-SIM (bHLH-PAS) ligand-activated transcription factor (136). Evolutionarily well-conserved, and expressed across a diverse number of mammalian species, $\mathrm{AhR}$ is a prominent mediator of the biological response to synthetic and naturally occurring chemicals (102). Ligand binding results in translocation of AhR from the cytoplasm to the nucleus and subsequent dimerization with its binding partner, aryl hydrocarbon receptor nuclear translocator (ARNT). The activated AhR/ARNT heterodimer complex binds to DNA at specific response elements (typically dioxin or xenobiotic response elements; DRE or XRE) to activate the expression of AhR target genes, such as cytochrome P450s (CYP1A1) (140). This classical activation of AhR has been described in response to halogenated aromatic hydrocarbons (HAHs), such as PCDDs, TCDD (being the best characterized and most potent), PCDFs, several PCBs, and PAHs (339). 
AhR is expressed in adipocytes (354), and the adipocyte AhR has recently garnered increased attention for its role not only in the xenobiotic response of AT, but also as a regulator of body weight, fat mass, and lipid homeostasis (194) (39) (430). Several studies provide evidence of AhR-mediated regulation of AT function, but results have not been consistent. AhR activation was reported to suppress de novo lipogenesis, as mouse embryonic fibroblasts isolated from AhR deficient mice displayed enhanced triglyceride synthesis (26). These data are consistent with results from mice with adipocyte-specific deficiency in AhR, where mice displayed increased body weight, fat mass, AT inflammation, and decreased glucose tolerance compared to wild type mice when fed a high fat diet (39). In direct contrast, it was recently reported that high-fat fed mice with whole body deficiency of AhR were protected from obesity, insulin resistance, and adipose inflammation (430). In another study, aged, but not young mice with whole body AhR deficiency were reported to have impaired glucose tolerance compared to wild type controls, without concomitant differences in body weight between genotype (46). Differences in findings from mice with whole body AhR deficiency versus those with cell-specific deletions may result from diverging effects of AhR across multiple cell types. Taken together, data implicate AhR in the regulation of AT function, body weight and lipid homeostasis.

As a wide spectrum of ligands are capable of binding and activating AhR, its activation by various POPs may contribute to their observed effects on obesity and fat mass in human populations. The best characterized AhR agonists capable of eliciting effects in AT or adipocyte cell lines are TCDD and TCDD-like PCBs, which can be abolished by AhR antagonists (34) (121). Moreover, TCDD-induced impairment of adipogenesis in mouse embryonic fibroblasts was abolished when cells were isolated from AhR deficient mice (26). Further, effects of TCDD and TCDD-like PCBs to regulate the inflammatory response (204) (37) and glucose uptake in adipocytes (37) were AhR-mediated. In mice with whole body AhR deficiency, administration of PCB-77 resulted in adipocyte hypertrophy and increased body weight compared to wild-type mice (34). Moreover, effects of PCB-77 to impair glucose homeostasis and AT inflammation were abolished in mice with adipocyte-specific AhR deficiency (39).

PAHs are also high-affinity ligands for AhR (102). However, limited studies have defined effects of PAHs to regulate AT function and development of obesity. Exposure of mice to air pollution (a major source of PAHs) (377) or to benzo-[a]-pyrene (173) increased visceral AT, circulating inflammatory factors, AT macrophage infiltration, fat mass, body weight, and impaired whole body glucose tolerance (377). In humans, prenatal exposure to air pollution has been associated with increased body size in children (335) (260). Additionally, a consistent association exists between exposure to cigarette smoke (another PAH source) in utero and increased risk of overweight and or obesity in adulthood (300) (171). Whether PAH molecules impair AT function through AhR-mediated activation is unknown.

2. PPAR $\boldsymbol{\gamma}$-PPAR $\boldsymbol{\gamma}$, a ligand-activated nuclear transcription factor, is a central regulator of AT function. Specifically, the PPAR $\gamma 2$ isoform is predominantly expressed in adipose tissue, especially very early in adipose cell differentiation (365), and activation of PPAR $\gamma 2$ stimulates adipogenesis (393). Upon activation and formation of a heterodimer with the coactivator retinoid $\times$ receptor $(\mathrm{RXR}), \operatorname{PPAR} \gamma$ binds to PPAR $\gamma$ response elements to stimulate 
transcription of genes involved in adipogenesis, lipid metabolism, and glucose homeostasis (22). It is thought that inappropriate activation of PPAR $\gamma$ by some POPs may contribute to obesity. In particular, phthalates have been identified as modulators of PPAR $\gamma$. In 3T3-L1 adipocytes, activation of endogenous PPAR $\gamma$ target genes has been demonstrated by MEHP, monobenzyl phthalate (MBzP), and mono-sec-butyl phthalate (MBuP) (167). Moreover, direct activation of PPAR $\gamma$ by MEHP in 3T3-L1 adipocytes promoted adipocyte differentiation, albeit to a lesser extent than the known PPAR $\gamma$ agonist, rosiglitazone (115). Interestingly, compared to rosiglitazone, MEHP resulted in promotion of only a subset of PPAR $\gamma$ coregulators, indicating differential effects of MEHP versus rosiglitazone on PPAR $\gamma$ transcriptional activation of adipocyte gene expression (115).

Evidence suggests a link between AhR binding by POPs and PPAR $\gamma$ activation. Reduced differentiation of 3T3-L1 cells to adipocytes by TCDD (71) (161) (320), PCBs (121), or DDT (278) was associated with decreased PPAR $\gamma$ gene expression. Further, TCDD suppressed PPAR $\gamma$ and adipogenesis via a MEK/ERK mechanism (79). In contrast, in mouse embryonic fibroblasts, AhR-mediated inhibition of adipogenesis preceded suppression of PPAR $\gamma$ activity (26). Thus, changes in PPAR $\gamma$ expression in response to TCDD may reflect reduced adipocyte differentiation rather than a direct effect of AhR activation to decrease PPAR $\gamma$.

One additional class of POPs that may influence PPAR $\gamma$ activity is organotins. Compounds such as tributyltin chloride (TBT) and bis(triphenyltin) oxide (TPTO) have been demonstrated to promote adipogenesis in 3T3-L1 cells through activation of PPAR $\gamma$ (186) (236). The effects of these compounds to influence PPAR $\gamma$-mediated regulation of adipocyte function are thought to be through binding of the PPAR $\gamma$ binding partner, RXR (186) (221).

Although some BFRs have been associated with increased adipocyte differentiation, the mechanism has not been reported. The brominated analogs of BPA, TBBPA and TCBPA were demonstrated to bind to and activate PPAR $\gamma$ in reporter cell lines. It was observed that the bulkier the brominated BPA analogs, the greater their capacity to activate PPAR $\gamma$ (328). 3. Endocrine hormone receptors. Endocrine hormone receptors may be the target of many POPs. Endocrine disruption resulting from inappropriate interactions with these receptors can negatively influence obesity and AT function. Several POPs that accumulate in AT are reported to be xenoestrogens (environmental ligands capable of binding and influencing ER signaling) (334) (380) (220) (350), including BPA, DDT/DDE, methoxychlor, the PAH 2amino-1-methyl-6-phenylimidazo[4-5-b]pyridine (PhIP), TCDD, PCBs, polybrominated biphenyls (PBBs), and phthalate esters. Estrogen receptor (ER) $a$ and $\beta$ are primary mediators of the effects of estrogens. Estrogen binding to these nuclear receptors results in the formation of homodimer complexes that bind to the promoter regions (termed estrogen response elements, or EREs) of estrogen-responsive genes, many of which contribute to regulation of metabolism. In post-menopausal women or ovariectomized rodents, where estrogen is low, white adipose tissue mass, body weight, and insulin resistance are increased (387). ERa signaling is purported to modulate the beneficial metabolic effects of estrogens, such as anti-lipogenesis, insulin sensitivity and glucose tolerance, and reduction of body weight and adipose mass, whereas ER $\beta$ is thought to play a larger role in the maintenance of normal glucose and lipid homeostasis (117). ERa deficient mice are prone to obesity, 
exhibit increased visceral fat mass, decreased insulin sensitivity, and impaired glucose tolerance (149). ERs are expressed in AT (311) and adipocyte-specific deletion of ERa resulted in increased adiposity, AT inflammation and fibrosis (93).

In particular, BPA has garnered significant interest as an estrogenic compound. Despite having a relatively low affinity for the ER compared to that of estrogen (209), BPA is widely accepted to mimic the effects and potency of estrogen (410). However, BPA has been associated with increased adipocyte differentiation, body weight and fat mass, effects which are inconsistent with known ER-mediated reductions in adiposity as described above. A potential explanation for this discrepancy relates to a developmental window for the effects of BPA, as rodent studies have demonstrated a significant effect of prenatal BPA exposure to increase body weight, adipocyte hypertrophy, and adiposity in adults (410) (364) (272). In a recent study, BPA-mediated differentiation of human preadipocytes could be inhibited by an $\mathrm{ERa}$ antagonist (53). Estrogens contribute to an increase in adipocyte number (84). Thus, exposure to estrogen during a critical period of development may predispose for AT expansion, especially when children or adults are faced with a metabolic challenge, or in combination with exposure to other obesogenic environmental chemicals. The brominated BPA analogs TBBPA and TCBPA have also been described as ligands for ERs (329), but further mechanisms examining the role of these BFRs to modulate AT function through ERs have not been defined.

AhR has been reported to interact with endocrine hormone receptors, thus one mechanism by which AhR may mediate body weight and fat mass is through modulation of ERsignaling pathways. Ligand-bound AhR/ARNT has been demonstrated to directly associate with ERs (299); however, consequences of AhR/ER interaction are complex and not well understood. In general, crosstalk between ER and AhR is thought to be inhibitory with respect to ER signaling. An inhibitory effect of AhR on ER signaling is consistent with reports demonstrating AhR agonists increase body weight and adiposity, since deficiency of estrogen (387) or ERa (149) are associated with increased obesity and adipose mass.

Several mechanisms may contribute to inhibition of ER signaling as a result of ER/AhR crosstalk. First, TCDD-mediated expression of CYP1A1 and CYP1B1 has been reported to enhance metabolism of estrogen in some cell types (368) (366) (367). Although circulating estrogen levels were not altered in TCDD-treated rodents (355), no study has examined the relationship between AhR activation and adipose ER expression/activity. Moreover, ligandbound AhR/ARNT prevents ER promoter binding and downregulation of ER target genes (reviewed in (340)). Also, ligand-bound AhR has been demonstrated to participate in an E3 ubiquitin ligase complex targeting the ER to proteasomal degradation (298). Finally, AhR and ERa interact with several common nuclear coregulatory factors (340), including ARNT (57), suggesting competition for these factors could influence activation of either pathway.

Inhibition versus potentiation of ER signaling may depend on the presence or absence of estrogen. For example, AhR coactivation of ERa resulted in transcriptional activity from ERE-regulated genes in the absence of estradiol (299). Alternatively, in the presence of estradiol, ARNT was recruited to estrogen-responsive promoters leading to increased ER transcription (379). 
In addition to disruption of ER signaling, some lipophilic organochlorines may interfere with androgen receptor (AR) signaling. For example, DDT/DDE (191) and some PCBs (344) have been reported to act as AR antagonists. Testosterone has been shown to stimulate glucose uptake in adipocytes (271). Additionally, a positive correlation between insulin sensitivity and testosterone levels has been reported in males (321). Thus, antagonism of the AR by certain POPs may impair AT function through inhibition of glucose uptake.

AT is also a target of thyroid hormones, and thyroid hormone signaling through thyroid receptors (TRs) regulates lipid mobilization and storage. Disruption of TR signaling by certain POPs may contribute to dysregulation of AT function. For example, BPA has been reported to inhibit TR signaling through enhanced recruitment of corepressors (280); however, this effect of BPA has not been localized to AT. Exposure of rats to PDBEs resulted in increased circulating levels of thyroxine and altered glucose metabolism of isolated primary adipocytes, however there was no effect on body weight (155). Additionally, TCDD and certain PCBs have been suggested to be repressors of thyroid function, as exposed rodents (291) and humans (310) demonstrate compensatory increases in circulating levels of thyroid stimulating hormone. Future studies should address whether these TR-mediated effects are manifest in AT.

\section{Associations between POP exposures and the development of obesity and diabetes \\ Obesity}

The prevalence of obesity and its related comorbidities has been rising rapidly over the last three decades and is reaching epidemic proportions in the Western world, most notably in the US (244) (296). The rising prevalence of obesity becomes more alarming when considering that the comorbidities of overweight and obesity include an increased risk of type II diabetes and cardiovascular diseases (82) (273) (274), two leading causes of rising medical costs and poor prognosis in the US (266) (207). Interestingly, in parallel with the increased prevalence of obesity, the use and environmental levels of synthetic organic and inorganic chemicals has risen dramatically (35). Therefore, in addition to the importance of diet and exercise in the etiology of obesity (152), the hypothesis that exposure to environmental contaminants such as POPs contributes to the development of obesity is gaining popularity (35). The "obesogen hypothesis" proposes that exposure to environmental xenobiotic chemicals either in utero or throughout life contributes to the development of obesity (148) (109) (289). "Obesogens" have been defined as "molecules that inappropriately regulate lipid metabolism and adipogenesis to promote obesity" (135).

Previous reviews have investigated potential links between POPs and obesity (212) (228) (382); however, findings are often inconsistent between different POP classes and even within chemical congeners. Associations between POPs and obesity may be complicated by the lipophilicity of these compounds; obese individuals possess greater adiposity in which these lipophilic chemicals may be stored. Furthermore, obese individuals may consume more fatty foods rich in lipophilic chemicals and may, therefore, experience higher dietary exposure to POPs. Findings are further complicated by the dose and timing of exposure as 
well as the gender of the individual exposed. Although in vitro and animal studies have typically investigated very high doses of POPs in their research, there is evidence that physiological changes can occur at much lower doses of POPs, and that these effects do not exhibit monotonic dose-response relationships (426). Therefore, conflicting findings between a particular POP and obesity may be explained by the level of exposure within the population. For example, toxic, high-dose exposures may result in weight loss while lower levels of exposure, which are characteristic of the typical population and may be considered "safe," might promote obesity (134) (148) (35). Additionally, the effects of POPs on parameters of obesity often vary by gender (Tables 7 and 8 ), which may be due to the POP's ability to disrupt endocrine function and mimic estrogenic effects (51). Lastly, the time of exposure poses an important consideration for investigating associations between POPs and obesity. Many POPs, including PCBs, DDE and HCB have shown contrasting effects on body mass index (BMI) in prenatal versus adult exposures (212). As such, associations between POPs and obesity will be investigated separately based on the timing of exposure: prenatal and early life, or adult exposure. Regardless of these interactions and individual effects of the chemicals, the net result of POP mixtures appears to be weight gain.

\section{Prenatal and Early Exposure to POPs}

Amidst the growing prevalence of obesity, rampantly rising rates of childhood obesity has emerged as a critical public health concern. Prevalence of childhood obesity worldwide has risen sharply since the 1980s, reaching 42 million in 2013 with estimates that this number will increase to 70 million infants and children in 2025 (305). The heightened concern over the childhood obesity crisis stems from both short-term and long-term effects on health and longevity. In the short term, obese children possess a higher risk for cardiovascular disease (120) and prediabetes (234). However, and perhaps even more frightening, is the association between childhood obesity and future risk of obesity (255) (36) (139), cardiovascular disease, type II diabetes, and greater morbidity and mortality (255) (36) (139) (285) (369). Together, these findings support the hypothesis of the fetal origins of adult disease, which proposes that the environment of the fetus can determine health and disease outcomes later in life (360).

Therefore, in accordance with the obesogen hypothesis, prenatal and early life exposure represents a critical window during which children are particularly vulnerable to both the short-term and long-term effects of POPs on obesity (134) (325) (290) (192). Furthermore, prenatal and early life contexts represent particularly vulnerable periods for environmental exposures. The fetus is sensitive to chemical exposures, which can cross the fetal-maternal blood barrier (175). This increased susceptibility continues into early life, as children have different levels and sources of exposure. Children can experience the effects of maternal exposure to POPs even after birth, as chemicals appear in breastmilk and represent a source of exposure during breastfeeding (31). Furthermore, children are not simply "tiny adults"; they differ not only in size but also in metabolism and physiological function, such as higher caloric consumption consumed per kg body weight and higher minute ventilation (361) (74), which can put them at increased risk of exposure to environmental chemicals. We describe below evidence regarding exposures to specific POPs and the development of obesity and/or diabetes. 
1. PCBs and Dioxins-The effect of prenatal PCBs on obesity is inconclusive. Twelve of the 25 studies investigating prenatal PCBs found no association between prenatal and early exposure to PCBs and obesity (Table 7). However, of the 12 studies that did find an association between prenatal PCBs and obesity, 9 found that PCBs had an inverse association on measures of obesity, including birth weight $(131,151,284,308)$, growth rate (308), weight (174) (47) (176) (214), and BMI (104). Conversely, 5 studies found positive associations between prenatal and early PCB exposure and measures of obesity (104) (414) (383) (21) (408).

A factor that may complicate interpretation of these studies is differing effects of TCDD-like PCBs and non-TCDD-like PCBs, as well as different effects in males versus females. Two studies found differing effects between toxicants based on their similarity to TCDD within the same study population. In a study of early exposure in Flemish adolescents aged 14-15 years, serum TCDD-like PCBs were positively associated with increased BMI while nonTCDD-like PCBs were negatively associated with BMI in males and females (104). In a second study, which investigated prenatal PCBs and obesity in African American children of the National Collaborative Perinatal Project (NCPP), maternal levels of TCDD-like PCBs were negatively associated with girl's weight and marginally positively associated with boy's weight (214). Conversely, maternal levels of non-TCDD-like PCBs were not associated with weight (214). This study highlights a complexity in the relationship between prenatal PCBs and obesity: gender. Of the 14 studies that found some association between prenatal or early exposure to PCBs and obesity in study populations containing both males and females, 5 studies found different effects between males and females. For example, negative associations between PCB exposure and weight were reported in males with no effect in females (151) (174). Conversely, a positive association was reported between PCB exposures and obesity in females but not males (383) (408). Therefore, diverging effects of prenatal and early PCB exposure and obesity in males versus females may contribute to differences in findings between studies. In summary, study findings should consider gender of the population under study, as well as the type (e.g., TCDD-like) and/or individual congeners which are screened.

2. DDE and DDT-Fifteen of 24 studies that investigated DDE exposures found positive associations between prenatal and early exposure to DDE and measures of obesity including BMI (189) (402) (414) (265) (189) (95) (423), weight (174) (189) (127), overweight (21, $408)$, rapid growth (265) (407), and waist circumference $(383,402)(101,423)$. Only one 4year study on Russian boys aged 6-8 years found a negative association between DDE and BMI (58). Similar to PCBs and TCDD, there appear to be different effects between genders, as some studies found associations with obesity in females but not in males(95) (101) (408). Conversely, two studies found effects on BMI, waist circumference, and overweight and obesity at 9 years (423) and weight at 14 years (127) in males but not in females.

Additionally, an association between prenatal DDE and BMI z-score and rapid growth that was seen in both sexes was stronger in boys (265). Therefore, the evidence supporting a link between prenatal DDE exposure and obesity is compelling despite potentially different effects between genders. By comparison, the effect of prenatal DDE on birth weight is less conclusive. One study showed an association between prenatal DDE and birth weight (248) 
while another showed no association with birth weight (131). Therefore, while there is a strong argument for exposure to prenatal DDE and obesity in later life, the effects of DDE on birth weight are inconclusive and might be weakly associated with decreased birth weight.

Five studies investigating prenatal exposure to DDT and obesity outcomes were analyzed. Two studies in childhood and adolescent males found no association between prenatal DDT exposure and BMI in boys (126) (423). However, another study in 6.5-year-old children found a positive association between prenatal DDT and overweight in males but not in females (408). In a study of 7.5-year-old children of both genders, a nonsignificant association was found between maternal DDT and BMI and increased odds of overweight and obesity (422). Lastly, prenatal DDT was associated with decreased birth weight (248). Therefore, prenatal exposure to DDT may decrease birth weight while being weakly associated with overweight in childhood, particularly among boys.

\section{Hexachlorobenzene (HCB), $\beta$-Hexachlorocyclohexane $(\mathrm{HCH})$, and $\mathrm{OC}$}

pesticides-Of the 11 studies which investigated the role of prenatal or early exposure to $\mathrm{HCB}$ and obesity, 5 found positive associations with $\mathrm{HCB}$ exposure and obesity. Four of the 5 studies found association between prenatal and maternal exposure to HCB and parameters of obesity including BMI (402) (362) (21), rapid growth (405) (407), and increased overweight and obesity (362) (21) (407). One study investigating early exposure to HCB and obesity found that in 7 year olds, HCB exposure was associated with increased BMI and overweight. However, a study investigating early exposure to HCB in 8-22 year olds found no association between HCB exposure and obesity (384). Furthermore, there were 4 studies that found no association between prenatal HCB and BMI (265) (90), obesity (90), birth weight (248), or waist circumference (101). One study found that exposure to HCB in 14-15 year olds decreased BMI. Studies appear to support an association between prenatal HCB exposure and rapid growth and increased BMI and overweight, particularly in childhood. However, the relationship between HCB exposure and obesity in adolescents is inconclusive.

Three studies investigating the effect of prenatal exposure to $\mathrm{HCH}$ failed to support an association between HCH and BMI (265) (90), obesity (90), or birth weight (248). However, conflicting associations were found when studying early exposure to $\mathrm{HCH}$ and obesity. There was an inverse association between $\beta-\mathrm{HCH}$ exposure and $\mathrm{BMI}$ in Russian boys aged 8-9 over a 4-year study (58). Conversely, Spanish children of both genders exhibited positive associations between $\beta-\mathrm{HCH}$ and BMI and increased overweight at 7 years (21). These conflicting findings might be due to gender, as boys exhibit a negative association between $\beta-\mathrm{HCH}$ and obesity while a positive association was seen when children of both sexes were studied, of which $51.3 \%$ were female. Furthermore, the two populations might differ in dose, type, or duration of exposure, as the two studies differed in which chemicals were included in their screening in addition to $\beta-\mathrm{HCH}$.

A study investigating OC pesticides found no association between prenatal trans-nonachlor and oxychlordane and obesity or BMI at 7 years (90). However, the same study did find a positive association between prenatal dieldrin exposure and obesity but no association with BMI. 
4. Polybrominated flame retardants (BFRs)-As compared to the organochlorines, fewer studies have investigated the prenatal or early exposure effects of BFRs on obesity, and the results are inconsistent. Of the 5 studies analyzed for the effects of BFRs, two found positive associations while two studies found negative associations between BFRs and obesity. A study in pregnant Long-Evans hooded rats found that prenatal dosing with PBDE-99 increased rat offspring birth weight (238). Furthermore, studies in humans have found the prenatal PBB exposure (above $5 \mathrm{ppb}$ ) was associated with increased weight for height in females (47). Conversely, studies in Mexican-Americans from the Center for the Health Assessment of Mothers and Children of Salinas (CHAMACOS) found negative associations between maternal PBDE levels and BMI, waist circumference, and birth weight (113) (144). However, the association seen between PBDE and lower birth weight became nonsignificant when maternal weight gain was included in the analysis (144).

5. Polycyclic Aromatic Hydrocarbons (PAHs)—Maternal and early exposure to PAHs appears to have contrasting effects on birth weight and childhood obesity. Several studies have shown that maternal dietary (215) (180) and airborne PAH (215) exposure as well as PAH-DNA adduct levels in newborns (314) (315) are associated with reduced birth weight. Conversely, prenatal and early exposure to PAHs is positively associated with increased BMI, obesity, and waist circumference in childhood (197) (335) (346). Therefore, it appears that prenatal exposure to PAHs may reduce birth weight but increase the risk of childhood obesity.

6. Phthalate Esters-The findings of the relationship between prenatal and early exposure to phthalates and obesity is inconsistent and complicated by different effects between the two sexes and also between low molecular weight (LMW) and high molecular weight (HMW) phthalate metabolites. LMW metabolites, including MnBP, MEP, and MiBP, have been associated with childhood obesity (77) (145) (388) (59) (48). Conversely, HMW metabolites have been associated with lower weight gain and lower BMI z-scores in boys but higher BMI in girls (406).

7. Bisphenol A (BPA)-The effects of BPA seem to vary depending if the exposure was prenatal or early in life. Prenatal exposure to BPA has been shown to be negatively associated with BMI, adiposity, and percent body fat in young girls (403) (143) as well as associated with decreased birth weight (269). On the other hand, early exposure to BPA in ages $4-15$ has been associated with increased BMI, obesity, and waist circumference (403) (143) (405) (417) (394); however, one study did show a negative association between BPA levels and BMI in 6-9 year old girls (428). Therefore, prenatal exposure to BPA seems to decrease the risk of obesity later in life while postnatal early exposure in childhood seems to increase the risk of childhood obesity.

\section{Adult Exposure to POPs}

In addition to the growing burden of obesity in children, more than 1.9 billion adults (39\%) age 18 years and older were overweight in 2014, of which over 600 million (13\%) were obese (306). Because adults experience a longer duration and type of exposure to POPs, they are presented separately from prenatal exposure. Furthermore, because maternal levels of 
POPs can determine offspring health, adult women of the childbearing age are of particular interest in terms of obesity outcomes.

1. PCBs and Dioxins-The studies of PCBs and dioxins and obesity are, by far, the most complex of the POPs. Complications when studying PCBs and potential effects on obesity arise from different effects between congeners and genders and non-linear and inverted Ushaped associations. While dioxins have consistently shown positive associations with BMI (224), waist circumference (223), fat mass (332), and metabolic syndrome (399), PCBs have shown positive, negative, or null associations between studies. These consistencies appear to be due to different effects between congeners and between genders.

TCDD-like PCBs have been positively associated with BMI (312) (128) (104). However, the non-TCDD-like PCBs have produced more inconsistent associations. For example, nonTCDD-like PCBs have been both negatively (224) (106) (104) (128) and positively (312) (223) associated with BMI and waist circumference. Furthermore, less-chlorinated PCBs have been positively associated with weight gain (241) and fat mass, while highlychlorinated PCBs have been negatively associated with weight gain (241) and fat mass . Furthermore, several studies have reported conflicting associations with PCBs and obesity within the same study that varied by congener (226) (332). When PCBs were grouped together, positive associations were found with an increased risk of becoming obese (108), BMI (218), and waist circumference (223). Furthermore, in a study of obese adults without diabetes, adipose levels of PCBs were positively associated with weight, BMI, waist circumference, and visceral adipose tissue (107).

Additionally, studies have found different effects of PCBs between genders. In the PIVUS study by Lee et al. on older adults, women had positive associations between waist circumference and the PCB congeners 74, 99, 118, 138, 153, and 156, but negative associations with congeners 105 and 126 (226). Similar inconsistencies in waist circumference were present in men, with PCBs 156, 157, 169, 180, 189, and 209 positively associated and PCBs 74, 99, 106, 118, 126, 138, 153, 170, 194, and 206 negatively associated with waist circumference. As discussed previously, study results must be considered with attention to the specific congeners studied and the gender of the study population. Lastly, the effects of PCBs also vary by dose, with several studies reporting nonmonotonic and inverted U-shaped associations (226) (230) (96) (333) (223), indicating that lower doses of PCBs might produce greater effects on obesity development than higher doses.

2. DDE and DDT-Of the fourteen studies that measured DDE in regards to obesity outcomes, thirteen found positive associations and only one study found no association. Therefore, DDE has consistently been positively associated with BMI (230) (224) (107) (104) (218) (128) (164) (312) (343), waist circumference (223) (107) (226), and visceral and subcutaneous adipose tissue (107). Only two studies found sex differences in the relationship between DDE exposure and obesity. In a study of the NHANES 1999-2002 data set, DDE was positively associated with waist circumference in women but negatively associated in men (110). On the other hand, in the PIVUS study of older adults, Lee et al. found that DDE was associated with waist circumference in males but not in females (226). Therefore, the 
literature supports a positive association between DDE and obesity, although gender differences may exist.

Fewer studies have investigated a relationship between DDT and obesity. In the Coronary Artery Risk Development in Young Adults (CARDIA), a prospective study in young adults without diabetes, DDT positively predicted BMI (230). On the other hand, in a crosssectional study on Canadian males, DDT was not associated with BMI (312). However, these inconsistent results may be a result of gender differences, as a cross-sectional study on the 1999-2002 NHANES dataset found that DDT was positively associated with waist circumference in females, but negatively associated in males (110).

3. $\mathrm{HCB}, \beta-\mathrm{HCH}$, and $\mathrm{OC}$ pesticides-The effects of $\mathrm{HCB}, \beta-\mathrm{HCH}$, and the remaining organochlorine pesticides, such as oxychlordane, trans-nonachlor, mirex, and aldrin, are less clear than the strongly positive associations of DDE with obesity. However, the Prospective Investigation of the Vasculature in Uppsala Seniors (PIVUS) study in older adults found that the sum of OC pesticides was positively associated with weight gain (241). Of these pesticides, studies on $\mathrm{HCB}$ and $\beta-\mathrm{HCH}$ tend to support positive associations with obesity. HCB has been positively associated with BMI (104) (218) (128) (312), waist circumference (226) and fat mass (332) (230). Similarly, $\beta$-HCH has been positively associated with BMI (312) (106, 164), metabolic syndrome (391), waist circumference (106), and fat mass (106). The Chlordane constituents oxychlordane and trans-nonachlor have been positively associated with BMI (164), waist circumference (226), and visceral and subcutaneous adipose tissue (96). However, several studies have also shown no association between chlordane and measures of obesity (230) (224) (164). The other OC pesticides have not been studied as extensively; however, three studies have reported no association between mirex and BMI (230) (164) (312). On the other hand, aldrin has been positively associated with metabolic syndrome (MetS) (391).

4. BFRs-Two studies have investigated PBBs and PBDEs levels in adults, and both supported positive associations between BFR exposure and obesity. In a study of the 2003-2004 NHANES data set, PBB-153 was nonlinearly associated with MetS and WC; furthermore, PBDE-153 exhibited an inverted U-shaped association with MetS (239). These results indicate that potential associations between BFRs and obesity in adults may be complicated by nonmonotonic dose response curves. Additionally, a second study in pregnant women found that milk levels of PBDEs were associated with the mom's BMI (91). Therefore, not only were PBDE levels associated with maternal BMI, but these levels in milk also represent a source of early life exposure to BFRs in offspring, which represents a potential factor in health outcomes later in life.

5. PAHs-One study investigated urinary PAH metabolites and obesity; however, the results were inconsistent and varied between metabolites (324). While urinary 2phenanthrene was positively associated with obesity, 1-naphthalene was negatively associated with obesity in NHANES adults (324). Additionally, 2-naphthalene, 1phenanthrene and 2-phenanthrene were positively associated with MetS. Furthermore, studies on smoking cigarettes, which can be a source of exposure to PAHs, have found positive associations with central obesity (75). 
6. Phthalate Esters-As in prenatal exposure, the relationship between phthalates and adult obesity is complicated by gender, age, and differences between the groups of phthalate metabolites; however, studies generally support a positive association between phthalate exposure and adult obesity. In a study of the 1999-2002 NHANES data set, although females had higher urinary levels of phthalate metabolites, the strongest positive associations with BMI and WC were found in 20-59-year old males with MBzP, MEHHP, and MEOHP (145). For LMW metabolites, MEP was positively associated with BMI in adult males (2059 and 60-80 years old) and for adolescent and adult (20-59 years old) females; however, no association was found in adolescent males and an inverse relationship was found in older females (145). Furthermore, while MBP showed inverse trends with BMI and WC in 60-80 year olds and female adults (20-59 years old), positive trends existed in 20-59-year old males (145). Furthermore, while the high molecular weight metabolite MBzP had a positive association with BMI and WC of 20-59-year old males, no associations were seen in females (145). Of urinary DEHP metabolites, MEHP was inversely associated with BMI and WC in adolescent and adult females, but no associations were found in males. On the other hand, MEHHP was positively associated with BMI in males, but no associations were found in females (145). Again, apparent inconsistencies between studies on phthalates and obesity might be explained by the particular metabolites studied and the age and gender of study participants.

7. BPA—Few studies have investigated relationships between BPA and obesity. Three studies support positive associations between BPA exposure and abdominal obesity (65) (420) as well as WC (122).

\section{Diabetes}

The global prevalence of diabetes is staggering; the number of people with diabetes has risen from 108 million in 1980 to 422 million in 2014, corresponding to an increase from $4.7 \%$ to $8.5 \%$ of adults over 18 years of age (304). Type 1 diabetes (T1D) is an autoimmune disease characterized by insulin deficiency as a result of beta-cell failure. On the other hand, Type 2 diabetes (T2D) is characterized by insulin resistance and includes an alarming number of children and adolescents (424).

There has been a growing interest in the environmental contribution to the etiology of diabetes and obesity. In 2011, the US National Toxicology Program (NTP) and the National Institute of Environmental Health Sciences (NIEHS) conducted a workshop titled "Role of Environmental Chemicals in the Development of Diabetes and Obesity" to investigate the science studying POPs and their association to these two diseases. The workshop concluded that there is a strong argument for a role of POPs in the etiology of diabetes and obesity (390) (386). The importance of studying the influence of environmental pollutants on the development of these diseases has been acknowledged by the National Institutes of Health (NIH) (146), the National Institute of Diabetes and Digestive Kidney Diseases (NIDDK) (83) (24), and the White House Task Force on Childhood Obesity (40).

The ubiquitous exposure to low and chronic levels of POPs presents a complicating factor in linking these toxicants to diabetes, as there is no true reference population with zero 
exposure to POPs. Moreover, the majority of studies that have attempted to link POP exposures to diabetes have focused on background levels within the general population, as opposed to occupational exposures. Background level POP exposures within the general population are present as mixtures of chemicals. Therefore, findings from studies investigating individual POPS must be analyzed in reference to not only the other POPs studied, but also the total mixture of chemicals to which the population is exposed. Two prospective studies have investigated the effect of POPs as mixtures on diabetes incidence, and both studies found that exposure to POP mixtures is associated with a 3-5 time higher risk of developing T2D (227) (229). In the Coronary Artery Risk Development in Young Adults (CARDIA) study, an inverted U-shaped association between exposure to POP mixtures and diabetes was found in young adults (229). The inverted U-shaped association indicates a nonmonotonic dose-response relationship between POPs and diabetes. Similarly, in the Prospective Investigation of the Vasculature in Uppsala Seniors (PIVUS) study, an association between POP exposure and T2D in the elderly was found (227). However, while this association suggested nonlinearity (227), it was not a clear inverted U-shaped association as in the CARDIA study.

1. PCBs and Dioxins-High-dose, toxic levels of chemical exposure have been the focus of both animal and human studies to investigate associations between exposures and effects on human health. For example, early findings on the human effects of TCDD were studied in populations with occupational and accidental exposure, such as U.S. Air Force veterans exposed to Agent Orange in Vietnam (150) (200) (187) and workers and residents exposed to TCDD following accidents or spills at chemical plants (43) (437) (371). Unfortunately, these early findings were inconsistent, as positive (150) (200) (187), inverse (371) (437), and null associations (381) (413) were observed between TCDD and T2D.

The findings from the Air Force Study on Vietnam War veterans of Operation Ranch Hand exposed to Agent Orange highlight the perplexing relationship between POPs and T2D. Compared to those not exposed to TCDD-contaminated Agent Orange, US Air Force veterans exposed to Agent Orange had glucose abnormalities and a higher risk of T2D (150). However, a follow-up study excluded veterans exposed to Agent Orange and only considered veterans who did not come into contact with TCDD-contaminated herbicides and, therefore, had exposure levels consistent with background levels in the United States (247). In this second study, the dose-response relationships between TCDD and T2D were surprisingly stronger in veterans with background levels of exposure as compared to high occupational exposure to TCDD, indicating that not only do POPs have low level effects on T2D, but also that these associations might be unexpectedly stronger at lower, background exposure levels (247).

This puzzling association between lower doses of TCDD and T2D was reinforced by a study of occupational exposure following a chemical plant accident in Italy (43). Of residents living in high-, medium, and low-exposure areas surrounding the accident, there was higher T2D mortality in the medium-exposure area as compared to residents from the highexposure area (43). Furthermore, in occupational exposure studies on individuals with very high levels of TCDD exposure, no associations were found between TCDD exposure and T2D (61) (381) (437). In contrast, recent studies in heavily contaminated areas, such as 
Superfund sites, demonstrate associations between serum TCDD and PCB levels and T2D (357) (411) (401), as well as elevated glucose (218) (86). While it remains debatable whether direct associations exist between exposure levels and T2D, reports demonstrating that lower level POP exposures are associated with diabetes are alarming, as these levels can be found in most individuals, and certainly in the obese population. A summary of POPs and their links to T2D are presented in Table 9.

2. DDE and DDT_-In adults with both background and occupational exposure, DDE and DDT have been linked with diabetes and related phenotypes. For adults with higher than background exposure levels to environmental contaminants, two studies investigating a heavily polluted area of Eastern Slovakia found associations between DDE and DDT and diabetes (218) (401). In one study, DDE and DDT were associated with both prediabetes and diabetes in these heavily exposed Slovakian adults (401). In a second study in this Slovakian population, DDE correlated with fasting glucose and serum insulin (218). Furthermore, DDE was also found to have a positive association with diabetes prevalence in women in the Anniston Superfund site (357). In studies in adults with background levels of exposure to POPs, DDE has been associated with T2D prevalence (224) (80) (398) (24) (337) (85), glucose abnormalities (107), and HOMA-IR (230). Additionally, studies have found associations between DDT and diabetes (114) (85).

Of particular interest are two studies performed in obese adults with background exposure who underwent bariatric surgery, which allowed for the researchers to obtain fat depots and evaluate associations between adipose levels of DDE and diabetes (107) (316). Both serum and adipose levels of DDE were associated with glucose levels and an abnormal glucose tolerance test (GTT) (107). In a second study by Pestana et al., (316), not only were total POPs in adipose tissue associated with HOMA-IR and dysglycemia, but adipose levels of DDE were associated with glucose metabolism and HbAlc. Similar findings across studies, as well as associations between both serum and AT levels to diabetes, support potential contributions of DDE exposures to the development of diabetes.

3. $\mathrm{HCB}, \mathrm{HCH}$, and $\mathrm{OC}$ pesticides- $\mathrm{HCB}, \mathrm{HCH}$, and the $\mathrm{OC}$ pesticides, such as oxychlordane, heptachlor, trans-nonachlor, and aldrin, have consistently shown positive associations with diabetes. When grouped together as OC pesticides, studies have found associations with high fasting glucose (223), diabetes prevalence (225), and incident T2D (227). When investigated individually, studies of these pesticides have largely indicated positive associations between exposure levels and diabetes. $\mathrm{HCH}$ has been associated with prediabetes (401), diabetes (85), and elevated serum glucose (85), while HCB was associated with diabetes prevalence (80) (337) and incidence (429). Chlordane and its constituents and metabolites heptachlor, trans-nonachlor, and oxychlordane have found positive associations with diabetes. Of the chlordane constituents, trans-nonachlor and oxychlordane have been the most heavily studied. These constituents have been positively associated with T2D prevalence (224) (85) (24), diabetes incidence (227) (229), and HOMA-IR (222). In contrast, while low doses of mirex were found to be associated with diabetes incidence in young adults of the Coronary Artery Risk Development in Young Adults (CARDIA) study (229), mirex was negatively associated with diabetes in adults of 
the Mohawk Nation at Akwesasne (80). Despite these inconsistent findings for mirex, which might be due to differences in study population and outcomes (diabetes prevalence versus diabetes incidence), OC pesticides appear to be consistently associated with diabetes.

4. BFRs-Literature on polybrominated flame retardants and diabetes are inconsistent, with studies showing either positive or no associations. Two main categories of BFRs have been investigated-PBDEs and PBBs. Studies on PBDEs have produced inconsistent findings in relationship to obesity, which may represent differing effects between PBDE congeners. In NHANES 2003-2004, PBDE-153 showed positive associations with diabetes prevalence and glycemia (239). In the same study, PBDE-99, PBDE-100, PBDE-28, and PBDE-47 were not significantly associated with diabetes. However, in a study of a cohort of sport fish consumers, the sum of PBDEs and the PBDE congeners PBDE-47 and PBDE-153 were not associated with diabetes (398). As described previously for other POP classes, individual congeners of PBDE may have some association with obesity and/or diabetes, but generalizations from mixed exposures cannot be assumed.

The findings for PBBs are similarly inconsistent. While PBB-153 was found to be positively associated with prevalent diabetes and glycemia in adults within NHANES 2003-2004 (239), prospective studies on PBB exposures and diabetes incidence have been inconsistent in their findings. In the CARDIA prospective study, low doses of PBB-153 were found to be associated with an increased risk of diabetes incidence (229); however, a prospective study of a Michigan cohort found no association between PBB and diabetes incidence (411).

5. PAHs-Although PAHs have not been as extensively studied as other environmental contaminants for their potential relationship to diabetes, the studies reviewed here show positive associations between PAH exposure and diabetes. In studies of merged 2001-2006 NHANES data, urinary PAH biomarkers, 1-naphthalene, 2-naphthalene, 2-phenanthrene, and 1-pyrene were associated with diabetes in adults (28) (324). Furthermore, in a study of Chinese adults, urinary PAH metabolites had a dose-response association with an increased risk of diabetes (432). Therefore, although the literature for PAH exposure and diabetes is not as extensive as other POPs, results support an association between PAHs and diabetes prevalence.

6. Phthalate Esters-While studies have often found positive associations between phthalates and diabetes, there are inconsistent findings that may be attributable to differing effects between phthalate metabolites, categorized as DEHP metabolites, low molecular weight metabolites, or high molecular weight metabolites. Urinary DEHP metabolites (MEHP, MECPP, MEHHP, MEOHP) have been positively associated with diabetes (378), HOMA-IR (395) (163), insulin resistance (395), and fasting levels of blood glucose and insulin (163). However, studies on LMW metabolites (MEP, MBP, MiBP, and MBP) have yielded inconsistent results. In an analysis on the Nurses' Health Study (NHS) and NHSII female adults, MBP, MiBP, and total phthalate metabolites were positively associated with incident T2D in the younger NHSII cohort; however, no association was found between phthalates and incident T2D in the older NHS cohort (376). In data from NHANES 20012008 in adults without diabetes, MnBP and MiBP were positively associated with fasting blood levels of glucose and insulin and HOMA-IR (163). Furthermore, adult males in 
NHANES 1999-2002 had positive associations between MEP and HOMA (370). In contrast, results from studies in adults outside of NHANES have failed to show associations between LMW metabolites and diabetes. In NHANES adolescents and elderly Korean adults, no associations were found between LMW phthalates and HOMA-IR (201) (395). The high molecular weight metabolites (MBzP, MCPP) have yielded perhaps the most inconsistent results. While MECPP positively associated with fasting blood levels of glucose and insulin and HOMA-IR (163), MBzP has been both positively and negatively associated with diabetes. In 1999-2002 NHANES, MBzP was associated with increased HOMA in adult males (370). However, in a study of healthy Mexican women, MBzP was negatively associated with diabetes (378). Therefore, the effect of phthalates on diabetes may differ depending on the particular metabolite examined, but also depending on the gender of the exposed individual. 7. BPA. Results from studies examining BPA exposures have generally supported a positive association between both serum and urine BPA and diabetes incidence (376), diabetes prevalence (20) (23) (349) (216), HbA1c (23), and impaired fasting glucose (20). However, two studies found no association between BPA and diabetes (201) (376). Differences in the relationship between BPA and diabetes between these studies could potentially be explained by the age of the population or the amount or duration of exposure.

In summary, in general, evidence supports an association between POPs, obesity and diabetes, particularly among the extensively-studied organochlorines. The relationship between POPs and obesity and diabetes may be complicated by differing effects between individual congeners, between genders, and between ages. Age may add complexity to the study of the role of environmental pollutants on diabetes due to the two phases of diabetes pathogenesis: insulin resistance and beta cell dysfunction. The age at the time of study and the age of diabetes onset may determine the relative importance of each phase of pathogenesis, as age is associated with greater beta cell dysfunction and insulin secretory effects (68). The stage of diabetes pathogenesis of the individuals within a study may, therefore, result in distinctive overall associations with POPs and dose-response relationships. Furthermore, an interaction of age on the association between adiposity and diabetes risk has been suggested (45), which deserves particular attention considering the complexity that obesity adds to the study of diabetes.

The consistent findings of nonmonotonic and inverted U-shaped associations between POPs (particularly PCBs) and disease outcomes are of particular interest. As compared to a linear dose response, in which the sign of the slope (i.e. negative or positive) does not change, a nonmonotonic relationship is characterized by a dose response curve with a slope that changes sign over the range of concentrations studied. These nonmonotonic dose response relationships indicate that lower levels of POPs, such as those in background levels of the general population, may be more harmful in terms of the development of diabetes and obesity than high exposures experienced in chemical spills. An inverted U-shaped association indicates that the maximal effect (i.e. highest disease incidence or prevalence) is observed at intermediate concentrations of POPs and drops off at increasing doses. Inverted U-shaped associations could explain the seemingly conflicting results of studies investigating the effects of POPs on obesity and diabetes. Different studies may indeed investigate different portions of the U-shaped curve based on the range of exposure 
concentrations studied. For example, studies in a population with low exposures may observe the initial positive linear portion of the inverted $U$, while studies in populations with intermediate and high exposure concentrations could experience null or inverse associations. Furthermore, studies are complicated by the lack of a true reference population, as all individuals are exposed to some level of POPs. Therefore, low, chronic exposure to POPs may be more detrimental to health than previously thought. The effects at background levels of exposure may not be properly predicted by studies performed in populations with high, occupational exposure in POPs exhibiting nonmonotonic dose responses.

Potential mechanisms to explain the inverted U-shaped associations observed in studies of the effect of exposure to POPs on obesity and diabetes may stem from the effects these toxicants have as endocrine-disrupting chemicals, including cytotoxicity, cell-specific receptors, differences in receptor selectivity, receptor downregulation, desensitization, and receptor competition (409). Cytotoxicity, perhaps the simplest explanation for nonmonotonic responses, could explain how disease prevalence is increased at low concentrations, at which the toxicant can exert physiological effects, but disease prevalence drops off at higher concentrations at which the POP becomes acutely toxic (409). Furthermore, dose response to POPs is complicated by cell-specific receptors that can activate different pathways. Different receptors may have different responses to a POP, and a single cell might exhibit different responses at different concentrations of exposure; as such, these overlapping responses can create an nomonotonic association overall (409). Furthermore, a response to a particular POP may decrease at increasing concentrations due to receptor downregulation, degradation, and desensitization (409). Therefore, an inverted U-shape curve may result from a decreased number of receptors or a decreased receptor response at increasing concentrations of POPs. An additional factor that may contribute to nonmontonic associations between exposure levels and disease is the ability of some POPs to induce enzymes involved in their own metabolism and detoxification. Lastly, nonmonotonic responses can occur due to receptor competition, which may be particularly relevant given that exposure, particularly background levels of exposure, to POPs occurs as a mixture and not as a single toxicant.

Obesity contributes to the development of diabetes; furthermore, as previously discussed, increased consumption of fatty foods can increase the body burden of lipophilic POPs, and expanded adipose tissue in obesity serves as a reservoir of POPs. Just as obesity and weight loss can alter the balance between sequestration in fat and release of POPs into the bloodstream, diabetes development and progression may influence the circulating levels of POPs, which raises issues of potential reverse causality. Just as circulating POP levels are dictated not only by exposure, but also by the individual's history of weight gain and loss, serum levels of POPs at the time of study may be influenced by the progression of diabetes, complicating any potential associations. Simply put, are higher serum levels of POPs contributing to the development and progression of diabetes or is diabetes pathogenesis altering the metabolism of POPs, leading to an increase in serum levels? These are important considerations to be made when analyzing the existing literature and when formulating new studies on POPs and health outcomes. 


\section{Conclusion}

It is clear that POPs have physical characteristics that enable their bioaccumulation in adipose tissue, resulting in greater body burdens of a wide array of environmental toxicants with distinct mechanisms of action in the setting of expanded AT mass. It is also clear that accumulating evidence supports a role for various POPs in the development of obesity, and in obesity-associated conditions such as type 2 diabetes. Association of POPs with obesity and/or diabetes have indicated that low level exposures, as would be experienced by the majority of US citizens, may influence not only the development of diabetes in adults, but also exert gestational influences that influence the health of offspring. There are many unanswered questions that warrant further investigation. Below, we summarize several unresolved issues and questions of significance related to POPs, AT, and disease development.

\section{Do POPs contribute to the development of obesity and diabetes?}

In 2013, at a National Toxicology Program Workshop, an evaluation of the literature in terms of consistency, strengths and weaknesses of the clinical diagnosis, exposure assessment and study population characteristics was performed to evaluate the area of POP exposures and diabetes outcomes (382). While the authors found that there was insufficient evidence to conclude a positive association of some organochlorine POPs with type 2 diabetes, strongest positive correlations occurred for DDE, PCBs, TCDD and TCDD-like chemicals. Within the appendix of this analysis, the authors provide an extensive list of data gaps and research recommendations that if performed, would provide more definitive information related to POP exposures and type 2 diabetes. It is unclear if any of these issues have been resolved to move this field forward.

\section{Is bioaccumulation of POPs in AT helpful or harmful?}

The physical chemical properties of POPs result in their bioaccumulation within adipocyte lipids. When trapped in triacylglycerol lipid droplets, POPs are sequestered away from target effectors, suggesting that bioaccumulation in adipocyte lipids may minimize harmful effects of POPs. However, sequestered POPs dynamically equilibrate between adipocyte lipids and the intracellular/extracellular environment, most likely resulting in low level tonic stimulation of effectors. Moreover, given that the total body burdens of lipophilic POPs increase with their bioaccumulation in an expanded AT mass of obese subjects, and that many POPs exert inflammatory actions that could contribute to the development of insulin resistance, low level POP exposures may contribute to the development of diabetes and other inflammatory-related conditions. Alternatively, when lipids are mobilized from adipocyte stores, POPs also mobilize and can act at effector targets to negatively influence health. As an example, given that $66 \%$ of the adult population are overweight and/or obese and attempting to lose weight, lipolysis-mediated release of POPs may negatively influence AT (and other target organs), mitigating the positive health benefits of weight loss. Therefore, areas of additional investigation would be identification of therapies and/or approaches that mitigate the harmful effects of liberated POPs. Moreover, it would be informative to understand ramifications of rapid versus slow weight loss as a means of influencing the bioaccumulation, actions and elimination of POPs from the body. 


\section{What are the implications of mixtures of POPs and their influence on AT function?}

Our body burden of POPs reflects mixtures we are exposed to through the environment. As discussed, mechanisms of POPs to influence AT function vary, and this is complicated by not only differences in mechanism of action between parent compounds within mixtures, but also influences of metabolic bi-products of POP metabolism. Moreover, even within a given class of POPs, interactions with target effectors may occur through the same binding site, or through allosteric mechanisms, suggesting additive and/or synergistic effects of POP mixtures at a given target effector. An advantage of experimental models is that they enable investigators to determine effects of individual POPs at exposure levels that hopefully mimic those experienced by humans. However, humans are exposed to and bioaccumulate a broad array of POPs that are further influenced by not only the level of adiposity, but also influenced by the regional deposition of AT. Thus, further studies are needed to define molecular interactions of mixtures at specific target effectors, integrated whole body responses to POP mixtures, and the influence of regional AT deposition on bioaccumulation and health-related effects of POPs.

\section{Is biomedical remediation of POPs possible?}

Considerable efforts are underway to remediate POPs from our environment. In contrast, aside from reducing environmental exposures, there are few avenues available to remediate POP burdens from humans experiencing chronic low level exposures, or to treat acutely exposed populations. This is alarming, as obesity prevalence continues to increase in children and adults, resulting in greater body burdens of POPs. Moreover, a preponderance of evidence suggests that prenatal POP exposures negatively influence the health of offspring, and an alarming number of child-bearing women are overweight and/or obese and would predictably have increased body burdens of POPs during gestation. Thus, biomedical remediation is needed not only to influence the health of the mother, but to minimize potential harmful effects of POPs on future generations. Additional studies should identify potential therapies, including lifestyle interventions and/or pharmacologic approaches, that can mitigate the harmful effects of liberated or tonically released POPs that decrease the bioaccumulation of POPs in AT lipids, or that hasten their elimination.

\section{Are there variables that influence the bioaccumulation within and/or toxicity of POPs at AT?}

Results from human exposure studies suggest that dose-response relationships (e.g., nonmonotonic dose-response), gender, and POP chemical class influence their bioaccumulation in AT, effector mechanisms, and toxicity. However, mechanisms for these relationships are not well defined. For example, it is unclear why some studies indicate more prevalent associations between POP exposures and obesity/diabetes in females compared to males, or vice versa. Additional studies are warranted at the experimental level to dissect potential mechanisms for these variables and their influence on POP toxicity.

In conclusion, physical/chemical characteristics of lipophilic POPs result in their bioaccumulation in AT, a site where these toxicants not only are sequestered away from effector targets, but also where they may exert actions that influence metabolism. Given that almost all humans harbor some level of POPs, further studies are warranted to define their 
contribution to diseases of increasing prevalence (obesity, diabetes), mechanisms of action, effects of POP mixtures, and the development of biomedical remediation therapies.

\section{Acknowledgments}

The authors wish to acknowledge support from the National Institute of Environmental Health Sciences (P42 ES007380-21) and the National Institute of Diabetes, Kidney and Digestive Diseases (T32 DK007778) of the National Institutes of Health.

\section{References}

1. Dioxin and Related Compounds. Springer International Publishing; 2016. XVI, 462

2. Persistent Organic Pollutants. Springer US; 2001. IX, 272

3. U.S. Department of Health and Human Services PHS. , editor(ATSDR) AfTSaDR. Toxicological profile for Aldrin/Dieldrin. Atlanta, GA: 2002.

4. U.S. Department of Health and Human Services PHS. , editor(ATSDR) AfTSaDR. Toxicological profile for chlordane. Atlanta, GA: 1994.

5. U.S. Department of Health and Human Services PHS. , editor(ATSDR) AfTSaDR. Toxicological profile for Chlorinated Dibenzo-p-dioxins (CDDs). Atlanta, GA: 1998.

6. U.S. Department of Health and Human Services PHS. , editor(ATSDR) AfTSaDR. Toxicological profile for DDT, DDE, and DDD. Atlanta, GA: 2002.

7. U.S. Department of Health and Human Services PHS. , editor(ATSDR) AfTSaDR. Toxicological profile for Di(2-ethylhexyl) phthlate. Atlanta, GA: 2002.

8. U.S. Department of Health and Human Services PHS. , editor(ATSDR) AfTSaDR. Toxicological profile for Endosulfan. Atlanta, GA: 2013.

9. U.S. Department of Health and Human Services PHS. , editor(ATSDR) AfTSaDR. Toxicological profile for Endrin. Atlanta, GA: 1996.

10. U.S. Department of Health and Human Services PHS. , editor(ATSDR) AfTSaDR. Toxicological profile for Heptachlor and Heptachlor Epoxide. Atlanta, GA: 2007.

11. U.S. Department of Health and Human Services PHS. , editor(ATSDR) AfTSaDR. Toxicological profile for Hexachlorobenzene. Atlanta, GA: 2013.

12. U.S. Department of Health and Human Services PHS. , editor(ATSDR) AfTSaDR. Toxicological profile for Methoxychlor. Atlanta, GA: 2002.

13. U.S. Department of Health and Human Services PHS. , editor(ATSDR) AfTSaDR. Toxicological profile for Mirex and Chlordecone. Atlanta, GA: 1995.

14. U.S. Department of Health and Human Services PHS. , editor(ATSDR) AfTSaDR. Toxicological profile for Polychlorinated Biphenyls (PCBs). Atlanta, GA: 2000.

15. U.S. Department of Health and Human Services PHS. , editor(ATSDR) AfTSaDR. Toxicological profile for Toxaphene. Atlanta, GA: 2014.

16. U.S. Department of Health and Human Services PHS. , editor(ATSDR) AfTSaDR. Toxicological profile for Polycyclic Aromatic Hydrocarbons (PAHs). Atlanta, GA: 1995.

17. (EPA) USEPA. Ambient Water Quality Criteria for Aldrin/Dieldrin. Washington, DC: Environmental Protection Agency; 1980. edited by 440.5-80-0191980 E

18. (EPA) USEPA. Persistent Organic Pollutants: A Global Issue, A Global Response. https:// www.epa.gov/international-cooperation/persistent-organic-pollutants-global-issue-global-response. [March 15, 2016]

19. Adolfsson-Erici M, Åkerman G, McLachlan MS. Measuring bioconcentration factors in fish using exposure to multiple chemicals and internal benchmarking to correct for growth dilution. Environ Toxicol Chem. 2012; 31:1853-1860. [PubMed: 22639194]

20. Aekplakorn W, Chailurkit LO, Ongphiphadhanakul B. Relationship of serum bisphenol A with diabetes in the Thai population, National Health Examination Survey IV, 2009. J Diabetes. 2015; 7:240-249. [PubMed: 24720399] 
21. Agay-Shay K, Martinez D, Valvi D, Garcia-Esteban R, Basagana X, Robinson O, Casas M, Sunyer J, Vrijheid M. Exposure to Endocrine-Disrupting Chemicals during Pregnancy and Weight at 7 Years of Age: A Multi-pollutant Approach. Environ Health Perspect. 2015; 123:1030-1037. [PubMed: 25956007]

22. Ahmadian M, Suh JM, Hah N, Liddle C, Atkins AR, Downes M, Evans RM. PPARgamma signaling and metabolism: the good, the bad and the future. Nat Med. 2013; 19:557-566. [PubMed: 23652116]

23. Ahmadkhaniha R, Mansouri M, Yunesian M, Omidfar K, Jeddi MZ, Larijani B, Mesdaghinia A, Rastkari N. Association of urinary bisphenol a concentration with type-2 diabetes mellitus. J Environ Health Sci Eng. 2014; 12:64. [PubMed: 24625016]

24. Airaksinen R, Rantakokko P, Eriksson JG, Blomstedt P, Kajantie E, Kiviranta H. Association between type 2 diabetes and exposure to persistent organic pollutants. Diabetes Care. 2011; 34:1972-1979. [PubMed: 21816981]

25. Alawi MA, Tamimi S, Jaghabir M. Storage of organochlorine pesticides in human adipose tissues of Jordanian males and females. Chemosphere. 1999; 38:2865-2873. [PubMed: 10214717]

26. Alexander DL, Ganem LG, Fernandez-Salguero P, Gonzalez F, Jefcoate CR. Aryl-hydrocarbon receptor is an inhibitory regulator of lipid synthesis and of commitment to adipogenesis. J Cell Sci. 1998; 111(Pt 22):3311-3322. [PubMed: 9788873]

27. Alonso-Magdalena P, Quesada I, Nadal A. Endocrine disruptors in the etiology of type 2 diabetes mellitus. Nat Rev Endocrinol. 2011; 7:346-353. [PubMed: 21467970]

28. Alshaarawy O, Zhu M, Ducatman AM, Conway B, Andrew ME. Urinary polycyclic aromatic hydrocarbon biomarkers and diabetes mellitus. Occup Environ Med. 2014; 71:437-441. [PubMed: 24638887]

29. Alvarez L, Randi A, Alvarez P, Kolliker Frers R, Kleiman de Pisarev DL. Effect of hexachlorobenzene on NADPH-generating lipogenic enzymes and L-glycerol-3-phosphate dehydrogenase in brown adipose tissue. J Endocrinol Invest. 1999; 22:436-445. [PubMed: 10435853]

30. Archibeque-Engle SL, Tessari JD, Winn DT, Keefe TJ, Nett TM, Zheng T. Comparison of organochlorine pesticide and polychlorinated biphenyl residues in human breast adipose tissue and serum. J Toxicol Environ Health. 1997; 52:285-293. [PubMed: 9354175]

31. Arendt M. Communicating human biomonitoring results to ensure policy coherence with public health recommendations: analysing breastmilk whilst protecting, promoting and supporting breastfeeding. Environ Health. 2008; 7(Suppl 1):S6.

32. Ariemma F, D'Esposito V, Liguoro D, Oriente F, Cabaro S, Liotti A, Cimmino I, Longo M, Beguinot F, Formisano P, Valentino R. Low-Dose Bisphenol-A Impairs Adipogenesis and Generates Dysfunctional 3T3-L1 Adipocytes. PLoS One. 2016; 11:e0150762. [PubMed: 26942597]

33. Arrebola JP, Pumarega J, Gasull M, Fernandez MF, Martin-Olmedo P, Molina-Molina JM, Fernández-Rodríguez M, Porta M, Olea N. Adipose tissue concentrations of persistent organic pollutants and prevalence of type 2 diabetes in adults from Southern Spain. Environ Res. 2013; 122:31-37. [PubMed: 23290489]

34. Arsenescu V, Arsenescu RI, King V, Swanson H, Cassis LA. Polychlorinated biphenyl-77 induces adipocyte differentiation and proinflammatory adipokines and promotes obesity and atherosclerosis. Environ Health Perspect. 2008; 116:761-768. [PubMed: 18560532]

35. Baillie-Hamilton PF. Chemical toxins: a hypothesis to explain the global obesity epidemic. J Altern Complement Med. 2002; 8:185-192. [PubMed: 12006126]

36. Baker JL, Olsen LW, Sorensen TI. Childhood body-mass index and the risk of coronary heart disease in adulthood. N Engl J Med. 2007; 357:2329-2337. [PubMed: 18057335]

37. Baker NA, English V, Sunkara M, Morris AJ, Pearson KJ, Cassis LA. Resveratrol protects against polychlorinated biphenyl-mediated impairment of glucose homeostasis in adipocytes. J Nutr Biochem. 2013; 24:2168-2174. [PubMed: 24231106]

38. Baker NA, Karounos M, English V, Fang J, Wei Y, Stromberg A, Sunkara M, Morris AJ, Swanson HI, Cassis LA. Coplanar polychlorinated biphenyls impair glucose homeostasis in lean C57BL/6 
mice and mitigate beneficial effects of weight loss on glucose homeostasis in obese mice. Environ Health Perspect. 2013; 121:105-110. [PubMed: 23099484]

39. Baker NA, Shoemaker R, English V, Larian N, Sunkara M, Morris AJ, Walker M, Yiannikouris F, Cassis LA. Effects of Adipocyte Aryl Hydrocarbon Receptor Deficiency on PCB-Induced Disruption of Glucose Homeostasis in Lean and Obese Mice. Environ Health Perspect. 2015; 123:944-950. [PubMed: 25734695]

40. Barnes M. White House Task Force on Childhood Obesity Report to the President. Washington, DC: 2010. Solving the problem of childhood obesity within a generation.

41. Barrett JR. POPs vs. fat: persistent organic pollutant toxicity targets and is modulated by adipose tissue. Environ Health Perspect. 2013; 121:a61. [PubMed: 23380189]

42. Bennett GW, Ballee DL, Hall RC, Fahey JE, Butts WL, Osmun JV. Persistence and distribution of chlordane and dieldrin applied as termiticides. Bull Environ Contam Toxicol. 1974; 11:64-69. [PubMed: 4433785]

43. Bertazzi PA, Bernucci I, Brambilla G, Consonni D, Pesatori AC. The Seveso studies on early and long-term effects of dioxin exposure: a review. Environ Health Perspect. 1998; 106(Suppl 2):625633. [PubMed: 9599710]

44. Biemann R, Navarrete Santos A, Navarrete Santos A, Riemann D, Knelangen J, Bluher M, Koch $\mathrm{H}$, Fischer B. Endocrine disrupting chemicals affect the adipogenic differentiation of mesenchymal stem cells in distinct ontogenetic windows. Biochem Biophys Res Commun. 2012; 417:747-752. [PubMed: 22197818]

45. Biggs ML, Mukamal KJ, Luchsinger JA, Ix JH, Carnethon MR, Newman AB, de Boer IH, Strotmeyer ES, Mozaffarian D, Siscovick DS. Association between adiposity in midlife and older age and risk of diabetes in older adults. JAMA. 2010; 303:2504-2512. [PubMed: 20571017]

46. Biljes D, Hammerschmidt-Kamper C, Kadow S, Diel P, Weigt C, Burkart V, Esser C. Impaired glucose and lipid metabolism in ageing aryl hydrocarbon receptor deficient mice. EXCLI J. 2015; 14:1153-1163. [PubMed: 26664351]

47. Blanck HM, Marcus M, Rubin C, Tolbert PE, Hertzberg VS, Henderson AK, Zhang RH. Growth in girls exposed in utero and postnatally to polybrominated biphenyls and polychlorinated biphenyls. Epidemiology. 2002; 13:205-210. [PubMed: 11880762]

48. Boas M, Frederiksen H, Feldt-Rasmussen U, Skakkebaek NE, Hegedus L, Hilsted L, Juul A, Main KM. Childhood exposure to phthalates: associations with thyroid function, insulin-like growth factor I, and growth. Environ Health Perspect. 2010; 118:1458-1464. [PubMed: 20621847]

49. Bodin J, Stene LC, Nygaard UC. Can exposure to environmental chemicals increase the risk of diabetes type 1 development? Biomed Res Int. 2015; 2015:208947. [PubMed: 25883945]

50. Bondy G, Armstrong C, Coady L, Doucet J, Robertson P, Feeley M, Barker M. Toxicity of the chlordane metabolite oxychlordane in female rats: clinical and histopathological changes. Food Chem Toxicol. 2003; 41:291-301. [PubMed: 12480304]

51. Bonefeld-Jorgensen EC, Andersen HR, Rasmussen TH, Vinggaard AM. Effect of highly bioaccumulated polychlorinated biphenyl congeners on estrogen and androgen receptor activity. Toxicology. 2001; 158:141-153. [PubMed: 11275356]

52. Botella B, Crespo J, Rivas A, Cerrillo I, Olea-Serrano MF, Olea N. Exposure of women to organochlorine pesticides in Southern Spain. Environ Res. 2004; 96:34-40. [PubMed: 15261782]

53. Boucher JG, Boudreau A, Atlas E. Bisphenol A induces differentiation of human preadipocytes in the absence of glucocorticoid and is inhibited by an estrogen-receptor antagonist. Nutr Diabetes. 2014; 4:e102. [PubMed: 24418828]

54. Bourez S, Van den Daelen C, Le Lay S, Poupaert J, Larondelle Y, Thomé JP, Schneider YJ, Dugail I, Debier C. The dynamics of accumulation of PCBs in cultured adipocytes vary with the cell lipid content and the lipophilicity of the congener. Toxicol Lett. 2013; 216:40-46. [PubMed: 23164672]

55. Braun WH, Young JD, Blau GE, Gehring PJ. The pharmacokinetics and metabolism of pentachlorophenol in rats. Toxicol Appl Pharmacol. 1977; 41:395-406. [PubMed: 898206]

56. Brodie AE, Azarenko VA, Hu CY. 2,3,7,8-Tetrachlorodibenzo-p-dioxin (TCDD) inhibition of fat cell differentiation. Toxicol Lett. 1996; 84:55-59. [PubMed: 8597178] 
57. Brunnberg S, Pettersson K, Rydin E, Matthews J, Hanberg A, Pongratz I. The basic helix-loophelix-PAS protein ARNT functions as a potent coactivator of estrogen receptor-dependent transcription. Proc Natl Acad Sci U S A. 2003; 100:6517-6522. [PubMed: 12754377]

58. Burns JS, Williams PL, Sergeyev O, Korrick SA, Lee MM, Revich B, Altshul L, Del Prato JT, Humblet O, Patterson DG, Turner WE, Starovoytov M, Hauser R. Serum concentrations of organochlorine pesticides and growth among Russian boys. Environ Health Perspect. 2012; 120:303-308. [PubMed: 21984531]

59. Buser MC, Murray HE, Scinicariello F. Age and sex differences in childhood and adulthood obesity association with phthalates: analyses of NHANES 2007-2010. Int J Hyg Environ Health. 2014; 217:687-694. [PubMed: 24657244]

60. Butt CM, Berger U, Bossi R, Tomy GT. Levels and trends of poly- and perfluorinated compounds in the arctic environment. Sci Total Environ. 2010; 408:2936-2965. [PubMed: 20493516]

61. Calvert GM, Sweeney MH, Deddens J, Wall DK. Evaluation of diabetes mellitus, serum glucose, and thyroid function among United States workers exposed to 2,3,7,8-tetrachlorodibenzo-p-dioxin. Occup Environ Med. 1999; 56:270-276. [PubMed: 10450245]

62. Campioli E, Martinez-Arguelles DB, Papadopoulos V. In utero exposure to the endocrine disruptor di-(2-ethylhexyl) phthalate promotes local adipose and systemic inflammation in adult male offspring. Nutr Diabetes. 2014; 4:e115. [PubMed: 24799162]

63. Canada Go. Screening Assessment Report. Environment Canada HC. , editorCanada: Government of Canada; 2013.

64. Cariou R, Antignac JP, Zalko D, Berrebi A, Cravedi JP, Maume D, Marchand P, Monteau F, Riu A, Andre F, Le Bizec B. Exposure assessment of French women and their newborns to tetrabromobisphenol-A: occurrence measurements in maternal adipose tissue, serum, breast milk and cord serum. Chemosphere. 2008; 73:1036-1041. [PubMed: 18790516]

65. Carwile JL, Michels KB. Urinary bisphenol A and obesity: NHANES 2003-2006. Environ Res. 2011; 111:825-830. [PubMed: 21676388]

66. Cavender F, O’Donohue J. Phenols and Phenolics. In: Bingham E, John Cohrssen B, editorsPatty's Toxicology. Wiley \& Sons Inc; 2012.

67. Chamorro-Garcia R, Kirchner S, Li X, Janesick A, Casey SC, Chow C, Blumberg B. Bisphenol A diglycidyl ether induces adipogenic differentiation of multipotent stromal stem cells through a peroxisome proliferator-activated receptor gamma-independent mechanism. Environ Health Perspect. 2012; 120:984-989. [PubMed: 22763116]

68. Chang AM, Halter JB. Aging and insulin secretion. Am J Physiol Endocrinol Metab. 2003; 284:E7-12. [PubMed: 12485807]

69. Chapados NA, Casimiro C, Robidoux MA, Haman F, Batal M, Blais JM, Imbeault P. Increased proliferative effect of organochlorine compounds on human preadipocytes. Mol Cell Biochem. 2012; 365:275-278. [PubMed: 22350817]

70. Chemicals NRCUSoF-R. Toxicological Risks of Selected Flame-Retardant Chemicals. Washington, DC: National Academic Press (US); 2000.

71. Chen CL, Brodie AE, Hu CY. CCAAT/enhancer-binding protein beta is not affected by tetrachlorodibenzo-p-dioxin (TCDD) inhibition of 3T3-L1 preadipocyte differentiation. Obes Res. 1997; 5:146-152. [PubMed: 9112250]

72. Chevrier J, Dewailly E, Ayotte P, Mauriège P, Després JP, Tremblay A. Body weight loss increases plasma and adipose tissue concentrations of potentially toxic pollutants in obese individuals. Int $\mathbf{J}$ Obes Relat Metab Disord. 2000; 24:1272-1278. [PubMed: 11093288]

73. Chiang HC, Kuo YT, Shen CC, Lin YH, Wang SL, Tsou TC. Mono(2-ethylhexyl)phthalate accumulation disturbs energy metabolism of fat cells. Arch Toxicol. 2016; 90:589-601. [PubMed: 25543134]

74. Children CoPitDola. Pesticides in the Diets of Infants and Children. Washington (DC): 1993.

75. Chiolero A, Faeh D, Paccaud F, Cornuz J. Consequences of smoking for body weight, body fat distribution, and insulin resistance. Am J Clin Nutr. 2008; 87:801-809. [PubMed: 18400700]

76. Choi H, Jedrychowski W, Spengler J, Camann DE, Whyatt RM, Rauh V, Tsai WY, Perera FP. International studies of prenatal exposure to polycyclic aromatic hydrocarbons and fetal growth. Environ Health Perspect. 2006; 114:1744-1750. [PubMed: 17107862] 
77. Choi J, Eom J, Kim J, Lee S, Kim Y. Association between some endocrine-disrupting chemicals and childhood obesity in biological samples of young girls: a cross-sectional study. Environ Toxicol Pharmacol. 2014; 38:51-57. [PubMed: 24908636]

78. Chu I, Villeneuve DC, Secours V, Franklin C, Rock G, Viau A. Metabolism and tissue distribution of mono-2-ethylhexyl phthalate in the rat. Drug Metab Dispos. 1978; 6:146-149. [PubMed: 26529]

79. Cimafranca MA, Hanlon PR, Jefcoate CR. TCDD administration after the pro-adipogenic differentiation stimulus inhibits PPARgamma through a MEK-dependent process but less effectively suppresses adipogenesis. Toxicol Appl Pharmacol. 2004; 196:156-168. [PubMed: 15050417]

80. Codru N, Schymura MJ, Negoita S, Akwesasne Task Force on E. Rej R, Carpenter DO. Diabetes in relation to serum levels of polychlorinated biphenyls and chlorinated pesticides in adult Native Americans. Environ Health Perspect. 2007; 115:1442-1447. [PubMed: 17938733]

81. Cok I, Donmez MK, Satiroğlu MH, Aydinuraz B, Henkelmann B, Shen H, Kotalik J, Schramm KW. Concentrations of polychlorinated dibenzo-p-dioxins (PCDDs), polychlorinated dibenzofurans (PCDFs), and dioxin-like PCBs in adipose tissue of infertile men. Arch Environ Contam Toxicol. 2008; 55:143-152. [PubMed: 18166985]

82. Collins S. Overview of clinical perspectives and mechanisms of obesity. Birth Defects Res A Clin Mol Teratol. 2005; 73:470-471. [PubMed: 15959883]

83. Committee DMIC. Advances and Emerging Opportunities in Diabetes Research: A Stragegic Planning Report of the Diabetes Mellitus Interagency Coordinating Committee. US Department of Health and Human Services, National Institutes of Health, Diabetes Mellitus Interagency Coordinating Committee; 2011.

84. Cooke PS, Naaz A. Role of estrogens in adipocyte development and function. Exp Biol Med (Maywood). 2004; 229:1127-1135. [PubMed: 15564439]

85. Cox S, Niskar AS, Narayan KM, Marcus M. Prevalence of self-reported diabetes and exposure to organochlorine pesticides among Mexican Americans: Hispanic health and nutrition examination survey, 1982-1984. Environ Health Perspect. 2007; 115:1747-1752. [PubMed: 18087594]

86. Cranmer M, Louie S, Kennedy RH, Kern PA, Fonseca VA. Exposure to 2,3,7,8-tetrachlorodibenzop-dioxin (TCDD) is associated with hyperinsulinemia and insulin resistance. Toxicol Sci. 2000; 56:431-436. [PubMed: 10911003]

87. Crookes MJ, Howe PD. Environmental hazard assessment: halogenated naphthalenes. Department of the Environment BRE, Directorate for Air, Climate and Toxic Substances, Toxic Substances Division. , editorGarston, United Kingdom: 1993.

88. Cummings AM. Methoxychlor as a model for environmental estrogens. Crit Rev Toxicol. 1997; 27:367-379. [PubMed: 9263644]

89. Cupul-Uicab LA, Hernandez-Avila M, Terrazas-Medina EA, Pennell ML, Longnecker MP. Prenatal exposure to the major DDT metabolite 1,1-dichloro-2,2-bis(p-chlorophenyl)ethylene (DDE) and growth in boys from Mexico. Environ Res. 2010; 110:595-603. [PubMed: 20566194]

90. Cupul-Uicab LA, Klebanoff MA, Brock JW, Longnecker MP. Prenatal exposure to persistent organochlorines and childhood obesity in the US collaborative perinatal project. Environ Health Perspect. 2013; 121:1103-1109. [PubMed: 23799652]

91. Daniels JL, Pan IJ, Jones R, Anderson S, Patterson DG Jr, Needham LL, Sjodin A. Individual characteristics associated with PBDE levels in U.S. human milk samples. Environ Health Perspect. 2010; 118:155-160. [PubMed: 20056574]

92. Darnerud PO, Eriksen GS, Jóhannesson T, Larsen PB, Viluksela M. Polybrominated diphenyl ethers: occurrence, dietary exposure, and toxicology. Environ Health Perspect. 2001; 109(Suppl 1): 49-68. [PubMed: 11250805]

93. Davis KE, M DN, Sun K, W MS, J DB, J AZ, Zeve D, L DH, D WC, L MG, Xu Y, Z VW, S AK, Clegg DJ. The sexually dimorphic role of adipose and adipocyte estrogen receptors in modulating adipose tissue expansion, inflammation, and fibrosis. Mol Metab. 2013; 2:227-242. [PubMed: 24049737] 
94. De Bruijn J, Busser F, Seinen W, Hermens J. Determination of octanol/water partition coefficients for hydrophobic organic chemicals with the "slow-stirring" method. Environmental Toxicology and Chemistry. 1989; 8:499-512.

95. de Cock M, de Boer MR, Lamoree M, Legler J, van de Bor M. First year growth in relation to prenatal exposure to endocrine disruptors - a Dutch prospective cohort study. Int J Environ Res Public Health. 2014; 11:7001-7021. [PubMed: 25014249]

96. De Roos AJ, Ulrich CM, Sjodin A, McTiernan A. Adiposity, body composition, and weight change in relation to organochlorine pollutant plasma concentrations. J Expo Sci Environ Epidemiol. 2012; 22:617-624. [PubMed: 22588213]

97. Dearth MA, Hites RA. Complete analysis of technical chlordane using negative ionization mass spectrometry. Environmental Science and Technology. 1991; 25:245-254.

98. Debier C, Chalon C, Le Boeuf BJ, de Tillesse T, Larondelle Y, Thomé JP. Mobilization of PCBs from blubber to blood in northern elephant seals (Mirounga angustirostris) during the postweaning fast. Aquat Toxicol. 2006; 80:149-157. [PubMed: 16963131]

99. Debier C, Crocker DE, Houser DS, Vanden Berghe M, Fowler M, Mignolet E, de Tillesse T, Rees JF, Thomé JP, Larondelle Y. Differential changes of fat-soluble vitamins and pollutants during lactation in northern elephant seal mother-pup pairs. Comp Biochem Physiol A Mol Integr Physiol. 2012; 162:323-330. [PubMed: 22507522]

100. Debost-Legrand A, Warembourg C, Massart C, Chevrier C, Bonvallot N, Monfort C, Rouget F, Bonnet F, Cordier S. Prenatal exposure to persistent organic pollutants and organophosphate pesticides, and markers of glucose metabolism at birth. Environ Res. 2016; 146:207-217. [PubMed: 26775002]

101. Delvaux I, Van Cauwenberghe J, Den Hond E, Schoeters G, Govarts E, Nelen V, Baeyens W, Van Larebeke N, Sioen I. Prenatal exposure to environmental contaminants and body composition at age 7-9 years. Environ Res. 2014; 132:24-32. [PubMed: 24742724]

102. Denison MS, Heath-Pagliuso S. The Ah receptor: a regulator of the biochemical and toxicological actions of structurally diverse chemicals. Bull Environ Contam Toxicol. 1998; 61:557-568. [PubMed: 9841714]

103. Dewailly E, Mulvad G, Pedersen HS, Ayotte P, Demers A, Weber JP, Hansen JC. Concentration of organochlorines in human brain, liver, and adipose tissue autopsy samples from Greenland. Environ Health Perspect. 1999; 107:823-828.

104. Dhooge W, Den Hond E, Koppen G, Bruckers L, Nelen V, Van De Mieroop E, Bilau M, Croes K, Baeyens W, Schoeters G, Van Larebeke N. Internal exposure to pollutants and body size in Flemish adolescents and adults: associations and dose-response relationships. Environ Int. 2010; 36:330-337. [PubMed: 20181395]

105. Dirinck E, Dirtu AC, Jorens PG, Malarvannan G, Covaci A, Van Gaal LF. Pivotal Role for the Visceral Fat Compartment in the Release of Persistent Organic Pollutants During Weight Loss. J Clin Endocrinol Metab. 2015; 100:4463-4471. [PubMed: 26469381]

106. Dirinck E, Jorens PG, Covaci A, Geens T, Roosens L, Neels H, Mertens I, Van Gaal L. Obesity and persistent organic pollutants: possible obesogenic effect of organochlorine pesticides and polychlorinated biphenyls. Obesity (Silver Spring). 2011; 19:709-714. [PubMed: 20559302]

107. Dirinck EL, Dirtu AC, Govindan M, Covaci A, Van Gaal LF, Jorens PG. Exposure to persistent organic pollutants: relationship with abnormal glucose metabolism and visceral adiposity. Diabetes Care. 2014; 37:1951-1958. [PubMed: 24963112]

108. Donat-Vargas C, Gea A, Sayon-Orea C, Carlos S, Martinez-Gonzalez MA, Bes-Rastrollo M. Association between dietary intakes of PCBs and the risk of obesity: the SUN project. J Epidemiol Community Health. 2014; 68:834-841. [PubMed: 24759782]

109. Elobeid MA, Allison DB. Putative environmental-endocrine disruptors and obesity: a review. Curr Opin Endocrinol Diabetes Obes. 2008; 15:403-408. [PubMed: 18769210]

110. Elobeid MA, Padilla MA, Brock DW, Ruden DM, Allison DB. Endocrine disruptors and obesity: an examination of selected persistent organic pollutants in the NHANES 1999-2002 data. Int J Environ Res Public Health. 2010; 7:2988-3005. [PubMed: 20717554]

111. Epstein SS. Kepone-hazard evaluation. Sci Total Environ. 1978; 9:1-62. [PubMed: 74851] 
112. Ericson I, van Bavel B, Lindström G. Screening of persistent halogenated compounds in human adipose tissue and blood from Sweden. Man-Technology-Environment (MTM) Research Centre, Örebro University; SE-701 82 Örebro, Sweden: 2008.

113. Erkin-Cakmak A, Harley KG, Chevrier J, Bradman A, Kogut K, Huen K, Eskenazi B. In utero and childhood polybrominated diphenyl ether exposures and body mass at age 7 years: the CHAMACOS study. Environ Health Perspect. 2015; 123:636-642. [PubMed: 25738596]

114. Everett CJ, Frithsen IL, Diaz VA, Koopman RJ, Simpson WM Jr, Mainous AG 3rd. Association of a polychlorinated dibenzo-p-dioxin, a polychlorinated biphenyl, and DDT with diabetes in the 1999-2002 National Health and Nutrition Examination Survey. Environ Res. 2007; 103:413-418. [PubMed: 17187776]

115. Feige JN, Gelman L, Rossi D, Zoete V, Metivier R, Tudor C, Anghel SI, Grosdidier A, Lathion C, Engelborghs Y, Michielin O, Wahli W, Desvergne B. The endocrine disruptor monoethyl-hexylphthalate is a selective peroxisome proliferator-activated receptor gamma modulator that promotes adipogenesis. J Biol Chem. 2007; 282:19152-19166. [PubMed: 17468099]

116. Fernandez MF, Arrebola JP, Taoufiki J, Navalón A, Ballesteros O, Pulgar R, Vilchez JL, Olea N. Bisphenol-A and chlorinated derivatives in adipose tissue of women. Reprod Toxicol. 2007; 24:259-264. [PubMed: 17689919]

117. Foryst-Ludwig A, Kintscher U. Metabolic impact of estrogen signalling through ERalpha and ERbeta. J Steroid Biochem Mol Biol. 2010; 122:74-81. [PubMed: 20599505]

118. Fox K, Zauke GP, Butte W. Kinetics of bioconcentration and clearance of 28 polychlorinated biphenyl congeners in zebrafish (Brachydanio rerio). Ecotoxicol Environ Saf. 1994; 28:99-109. [PubMed: 7523072]

119. Frank R, Rasper J, Smout MS, Braun HE. Organochlorine Residues in Adipose Tissues, Blood and Milk from Ontario Residents, 1976-1985. Canadian Journal of Public Health. 1988; 79:150 158. [PubMed: 3135931]

120. Freedman DS, Mei Z, Srinivasan SR, Berenson GS, Dietz WH. Cardiovascular risk factors and excess adiposity among overweight children and adolescents: the Bogalusa Heart Study. J Pediatr. 2007; 150:12-17 e12. [PubMed: 17188605]

121. Gadupudi G, Gourronc FA, Ludewig G, Robertson LW, Klingelhutz AJ. PCB126 inhibits adipogenesis of human preadipocytes. Toxicol In Vitro. 2015; 29:132-141. [PubMed: 25304490]

122. Galloway T, Cipelli R, Guralnik J, Ferrucci L, Bandinelli S, Corsi AM, Money C, McCormack P, Melzer D. Daily bisphenol A excretion and associations with sex hormone concentrations: results from the InCHIANTI adult population study. Environ Health Perspect. 2010; 118:1603-1608. [PubMed: 20797929]

123. Gauthier MS, Rabasa-Lhoret R, Prud'homme D, Karelis AD, Geng D, van Bavel B, Ruzzin J. The metabolically healthy but obese phenotype is associated with lower plasma levels of persistent organic pollutants as compared to the metabolically abnormal obese phenotype. J Clin Endocrinol Metab. 2014; 99:E1061-1066. [PubMed: 24606089]

124. Geyer HJ, Rimkus GG, Scheunert I, Kaune A, Schramm K-W, Kettrup A, Zeeman M, Muir DCG, Hansen LG, Mackay D. Bioaccumulation-New Aspects and Developments. Springer; Berlin Heidelberg: 2000. Bioaccumulation and Occurrence of Endocrine-Disrupting Chemicals (EDCs), Persistent Organic Pollutants (POPs), and Other Organic Compounds in Fish and Other Organisms Including Humans; 1-166.

125. Giesy JP, Kannan K. Perfluorochemical surfactants in the environment. Environ Sci Technol. 2002; 36:146A-152A. [PubMed: 11827047]

126. Gladen BC, Klebanoff MA, Hediger ML, Katz SH, Barr DB, Davis MD, Longnecker MP. Prenatal DDT exposure in relation to anthropometric and pubertal measures in adolescent males. Environ Health Perspect. 2004; 112:1761-1767. [PubMed: 15579424]

127. Gladen BC, Ragan NB, Rogan WJ. Pubertal growth and development and prenatal and lactational exposure to polychlorinated biphenyls and dichlorodiphenyl dichloroethene. J Pediatr. 2000; 136:490-496. [PubMed: 10753247]

128. Glynn AW, Granath F, Aune M, Atuma S, Darnerud PO, Bjerselius R, Vainio H, Weiderpass E. Organochlorines in Swedish women: determinants of serum concentrations. Environ Health Perspect. 2003; 111:349-355. [PubMed: 12611665] 
129. Gobas FAPC, Clark KE, Shiu WY, MacKay D. Bioconcentration of polybrominated benzenes and biphenyls and related superhydrophobic chemicals in fish: Role of bioavailability and elimination into the feces. Environmental Toxicology and Chemistry. 1989; 8:231-245.

130. Gómez-Catalán J, To-Figueras J, Rodamilans M, Corbella J. Transport of organochlorine residues in the rat and human blood. Arch Environ Contam Toxicol. 1991; 20:61-66. [PubMed: 1996912]

131. Govarts E, Nieuwenhuijsen M, Schoeters G, Ballester F, Bloemen K, de Boer M, Chevrier C, Eggesbo M, Guxens M, Kramer U, Legler J, Martinez D, Palkovicova L, Patelarou E, Ranft U, Rautio A, Petersen MS, Slama R, Stigum H, Toft G, Trnovec T, Vandentorren S, Weihe P, Kuperus NW, Wilhelm M, Wittsiepe J, Bonde JP, Obelix, and Enrieco. Birth weight and prenatal exposure to polychlorinated biphenyls (PCBs) and dichlorodiphenyldichloroethylene (DDE): a meta-analysis within 12 European Birth Cohorts. Environ Health Perspect. 2012; 120:162-170. [PubMed: 21997443]

132. Grandjean P, Henriksen JE, Choi AL, Petersen MS, Dalgard C, Nielsen F, Weihe P. Marine food pollutants as a risk factor for hypoinsulinemia and type 2 diabetes. Epidemiology. 2011; 22:410 417. [PubMed: 21364465]

133. Grimm HG, Schellmann B, Schaller KH, Gossler K. [Pentachlorophenol concentrations in tissues and body fluids of normal persons (author's transl)]. Zentralbl Bakteriol Mikrobiol Hyg B. 1981; 174:77-90. [PubMed: 7324621]

134. Grun F, Blumberg B. Endocrine disrupters as obesogens. Mol Cell Endocrinol. 2009; 304:19-29. [PubMed: 19433244]

135. Grun F, Blumberg B. Environmental obesogens: organotins and endocrine disruption via nuclear receptor signaling. Endocrinology. 2006; 147:S50-55. [PubMed: 16690801]

136. Gu YZ, Hogenesch JB, Bradfield CA. The PAS superfamily: sensors of environmental and developmental signals. Annu Rev Pharmacol Toxicol. 2000; 40:519-561. [PubMed: 10836146]

137. Ha MH, Lee DH, Jacobs DR. Association between serum concentrations of persistent organic pollutants and self-reported cardiovascular disease prevalence: results from the National Health and Nutrition Examination Survey, 1999-2002. Environ Health Perspect. 2007; 115:1204-1209. [PubMed: 17687448]

138. Hamers T, Kamstra JH, Sonneveld E, Murk AJ, Kester MH, Andersson PL, Legler J, Brouwer A. In vitro profiling of the endocrine-disrupting potency of brominated flame retardants. Toxicol Sci. 2006; 92:157-173. [PubMed: 16601080]

139. Han JC, Lawlor DA, Kimm SY. Childhood obesity. Lancet. 2010; 375:1737-1748. [PubMed: 20451244]

140. Hankinson O. The aryl hydrocarbon receptor complex. Annu Rev Pharmacol Toxicol. 1995; 35:307-340. [PubMed: 7598497]

141. Hansch C, Leo A, Hoekman D. Exploring QSAR-Hydrophobic, Electronic, and Steric Constants. American Chemical Society; 1995. 557

142. Hao C, Cheng X, Xia H, Ma X. The endocrine disruptor mono-(2-ethylhexyl) phthalate promotes adipocyte differentiation and induces obesity in mice. Biosci Rep. 2012; 32:619-629. [PubMed: 22953781]

143. Harley KG, Aguilar Schall R, Chevrier J, Tyler K, Aguirre H, Bradman A, Holland NT, Lustig RH, Calafat AM, Eskenazi B. Prenatal and postnatal bisphenol A exposure and body mass index in childhood in the CHAMACOS cohort. Environ Health Perspect. 2013; 121:514-520. [PubMed: 23416456]

144. Harley KG, Chevrier J, Aguilar Schall R, Sjodin A, Bradman A, Eskenazi B. Association of prenatal exposure to polybrominated diphenyl ethers and infant birth weight. Am J Epidemiol. 2011; 174:885-892. [PubMed: 21878423]

145. Hatch EE, Nelson JW, Qureshi MM, Weinberg J, Moore LL, Singer M, Webster TF. Association of urinary phthalate metabolite concentrations with body mass index and waist circumference: a cross-sectional study of NHANES data, 1999-2002. Environ Health. 2008; 7:27. [PubMed: 18522739]

146. Health UDo, Services H, and Health NIo. Strategic plan for NIH obesity research. 2013. A report of the NIH Obesity Research Task Force (NIH publication no. 11-5493) 2011 
147. Hedgeman E, Chen Q, Hong B, Chang CW, Olson K, Ladronka K, Ward B, Adriaens P, Demond A, Gillespie BW, Lepkowski J, Franzblau A, Garabrant DH. The University of Michigan Dioxin Exposure Study: population survey results and serum concentrations for polychlorinated dioxins, furans, and biphenyls. Environ Health Perspect. 2009; 117:811-817. [PubMed: 19479026]

148. Heindel JJ, vom Saal FS. Role of nutrition and environmental endocrine disrupting chemicals during the perinatal period on the aetiology of obesity. Mol Cell Endocrinol. 2009; 304:90-96. [PubMed: 19433253]

149. Heine PA, Taylor JA, Iwamoto GA, Lubahn DB, Cooke PS. Increased adipose tissue in male and female estrogen receptor-alpha knockout mice. Proc Natl Acad Sci U S A. 2000; 97:12729_ 12734. [PubMed: 11070086]

150. Henriksen GL, Ketchum NS, Michalek JE, Swaby JA. Serum dioxin and diabetes mellitus in veterans of Operation Ranch Hand. Epidemiology. 1997; 8:252-258. [PubMed: 9115019]

151. Hertz-Picciotto I, Charles MJ, James RA, Keller JA, Willman E, Teplin S. In utero polychlorinated biphenyl exposures in relation to fetal and early childhood growth. Epidemiology. 2005; 16:648-656. [PubMed: 16135941]

152. Hill JO, Peters JC. Environmental contributions to the obesity epidemic. Science. 1998; 280:1371-1374. [PubMed: 9603719]

153. Hirai Y, Tomokuni K. Levels of chlordane, oxychlordane, and nonachlor in human adipose tissues. Bull Environ Contam Toxicol. 1991; 47:173-176. [PubMed: 1912692]

154. Hong NS, Kim KS, Lee IK, Lind PM, Lind L, Jacobs DR, Lee DH. The association between obesity and mortality in the elderly differs by serum concentrations of persistent organic pollutants: a possible explanation for the obesity paradox. Int J Obes (Lond). 2012; 36:11701175. [PubMed: 21946706]

155. Hoppe AA, Carey GB. Polybrominated diphenyl ethers as endocrine disruptors of adipocyte metabolism. Obesity (Silver Spring). 2007; 15:2942-2950. [PubMed: 18198302]

156. Hoppin JA, Brock JW, Davis BJ, Baird DD. Reproducibility of urinary phthalate metabolites in first morning urine samples. Environ Health Perspect. 2002; 110:515-518. [PubMed: 12003755]

157. Houlahan KE, Prokopec SD, Sun RX, Moffat ID, Linden J, Lensu S, Okey AB, Pohjanvirta R, Boutros PC. Transcriptional profiling of rat white adipose tissue response to $2,3,7,8-$ tetrachlorodibenzo-rho-dioxin. Toxicol Appl Pharmacol. 2015; 288:223-231. [PubMed: 26232522]

158. Howard P, Meylan W. Handbook of physical properties of organic chemicals. Lewis Publishers; 1997.

159. Howard PH, editorHandbook of environmental fate and exposure data for organic chemicals. Chelsea, MI: Lewis Publishers Inc; 1991. 502-504.

160. Howell G 3rd, Mangum L. Exposure to bioaccumulative organochlorine compounds alters adipogenesis, fatty acid uptake, and adipokine production in NIH3T3-L1 cells. Toxicol In Vitro. 2011; 25:394-402. [PubMed: 21044676]

161. Hsu HF, Tsou TC, Chao HR, Kuo YT, Tsai FY, Yeh SC. Effects of 2,3,7,8-tetrachlorodibenzo-pdioxin on adipogenic differentiation and insulin-induced glucose uptake in 3T3-L1 cells. J Hazard Mater. 2010; 182:649-655. [PubMed: 20633992]

162. Hu H, Xu F, Li B, Cao J, Dawson R, Tao S. Prediction of the Bioconcentration Factor of PCBs in Fish Using the Molecular Connectivity Index and Fragment Constant Models. Water Environment Research. 2005; 77:87-97. [PubMed: 15765940]

163. Huang T, Saxena AR, Isganaitis E, James-Todd T. Gender and racial/ethnic differences in the associations of urinary phthalate metabolites with markers of diabetes risk: National Health and Nutrition Examination Survey 2001-2008. Environ Health. 2014; 13:6. [PubMed: 24499162]

164. Hue O, Marcotte J, Berrigan F, Simoneau M, Dore J, Marceau P, Marceau S, Tremblay A, Teasdale N. Plasma concentration of organochlorine compounds is associated with age and not obesity. Chemosphere. 2007; 67:1463-1467. [PubMed: 17126879]

165. Huff JE, Gerstner HB. Kepone: a literature summary. J Environ Pathol Toxicol. 1978; 1:377-395. [PubMed: 82598] 
166. Hugo ER, Brandebourg TD, Woo JG, Loftus J, Alexander JW, Ben-Jonathan N. Bisphenol A at environmentally relevant doses inhibits adiponectin release from human adipose tissue explants and adipocytes. Environ Health Perspect. 2008; 116:1642-1647. [PubMed: 19079714]

167. Hurst CH, Waxman DJ. Activation of PPARalpha and PPARgamma by environmental phthalate monoesters. Toxicol Sci. 2003; 74:297-308. [PubMed: 12805656]

168. Information NCfB. Compound Summary for CID 6618 (Tetrabromobisphenol A) PubChem Compound Database. 2005

169. Information NCfB. Compound Summary for CID 8343 PubChem Compound Database. 2004

170. Information NCfB. Compound Summary for CID 20393 PubChem Compound Database. 2004

171. Ino T. Maternal smoking during pregnancy and offspring obesity: meta-analysis. Pediatr Int. 2010; 52:94-99. [PubMed: 19400912]

172. Irigaray P, Lacomme S, Mejean L, Belpomme D. Ex vivo study of incorporation into adipocytes and lipolysis-inhibition effect of polycyclic aromatic hydrocarbons. Toxicol Lett. 2009; 187:3539. [PubMed: 19429241]

173. Irigaray P, Ogier V, Jacquenet S, Notet V, Sibille P, Mejean L, Bihain BE, Yen FT. Benzo[a]pyrene impairs beta-adrenergic stimulation of adipose tissue lipolysis and causes weight gain in mice. A novel molecular mechanism of toxicity for a common food pollutant. FEBS J. 2006; 273:1362-1372. [PubMed: 16689925]

174. Iszatt N, Stigum H, Verner MA, White RA, Govarts E, Murinova LP, Schoeters G, Trnovec T, Legler J, Pele F, Botton J, Chevrier C, Wittsiepe J, Ranft U, Vandentorren S, Kasper-Sonnenberg M, Klumper C, Weisglas-Kuperus N, Polder A, Eggesbo M, Obelix. Prenatal and Postnatal Exposure to Persistent Organic Pollutants and Infant Growth: A Pooled Analysis of Seven European Birth Cohorts. Environ Health Perspect. 2015; 123:730-736. [PubMed: 25742056]

175. Jacobson JL, Jacobson SW. Intellectual impairment in children exposed to polychlorinated biphenyls in utero. N Engl J Med. 1996; 335:783-789. [PubMed: 8703183]

176. Jacobson JL, Jacobson SW, Humphrey HE. Effects of exposure to PCBs and related compounds on growth and activity in children. Neurotoxicol Teratol. 1990; 12:319-326. [PubMed: 2118230]

177. Jamaluddin MS, Weakley SM, Yao Q, Chen C. Resistin: functional roles and therapeutic considerations for cardiovascular disease. Br J Pharmacol. 2012; 165:622-632. [PubMed: 21545576]

178. Jan J. Chlorobenzene residues in human fat and milk. Bull Environ Contam Toxicol. 1983; 30:595-599. [PubMed: 6860813]

179. Jarosova A, Harazim J, Suchy P, Kratka L, Stancova V. The distribution and accumulation of phthalates in the organs and tissues of chicks after the administration of feedstuffs with different phthalate concentrations. Veterinarni Medicina. 2009; 54:427-434.

180. Jedrychowski W, Perera FP, Tang D, Stigter L, Mroz E, Flak E, Spengler J, Budzyn-Mrozek D, Kaim I, Jacek R. Impact of barbecued meat consumed in pregnancy on birth outcomes accounting for personal prenatal exposure to airborne polycyclic aromatic hydrocarbons: Birth cohort study in Poland. Nutrition. 2012; 28:372-377. [PubMed: 22079395]

181. Jimenez Torres M, Campoy Folgoso C, Cañabate Reche F, Rivas Velasco A, Cerrillo Garcia I, Mariscal Arcas M, Olea-Serrano F. Organochlorine pesticides in serum and adipose tissue of pregnant women in Southern Spain giving birth by cesarean section. Sci Total Environ. 2006; 372:32-38. [PubMed: 16904732]

182. Johnson-Restrepo B, Adams DH, Kannan K. Tetrabromobisphenol A (TBBPA) and hexabromocyclododecanes (HBCDs) in tissues of humans, dolphins, and sharks from the United States. Chemosphere. 2008; 70:1935-1944. [PubMed: 18037156]

183. Johnson-Restrepo B, Kannan K, Rapaport DP, Rodan BD. Polybrominated diphenyl ethers and polychlorinated biphenyls in human adipose tissue from New York. Environ Sci Technol. 2005; 39:5177-5182. [PubMed: 16082945]

184. Jorgenson JL. Aldrin and dieldrin: a review of research on their production, environmental deposition and fate, bioaccumulation, toxicology, and epidemiology in the United States. Environ Health Perspect. 2001; 109(Suppl 1):113-139. [PubMed: 11250811]

185. Kamstra JH, Hruba E, Blumberg B, Janesick A, Mandrup S, Hamers T, Legler J. Transcriptional and epigenetic mechanisms underlying enhanced in vitro adipocyte differentiation by the 
brominated flame retardant BDE-47. Environ Sci Technol. 2014; 48:4110-4119. [PubMed: 24559133]

186. Kanayama T, Kobayashi N, Mamiya S, Nakanishi T, Nishikawa J. Organotin compounds promote adipocyte differentiation as agonists of the peroxisome proliferator-activated receptor gamma/ retinoid X receptor pathway. Mol Pharmacol. 2005; 67:766-774. [PubMed: 15611480]

187. Kang HK, Dalager NA, Needham LL, Patterson DG Jr, Lees PS, Yates K, Matanoski GM. Health status of Army Chemical Corps Vietnam veterans who sprayed defoliant in Vietnam. Am J Ind Med. 2006; 49:875-884. [PubMed: 17006952]

188. Kannan K, Corsolini S, Falandysz J, Fillmann G, Kumar KS, Loganathan BG, Mohd MA, Olivero J, Van Wouwe N, Yang JH, Aldoust KM. Perfluorooctanesulfonate and related fluorochemicals in human blood from several countries. Environ Sci Technol. 2004; 38:4489-4495. [PubMed: 15461154]

189. Karmaus W, Osuch JR, Eneli I, Mudd LM, Zhang J, Mikucki D, Haan P, Davis S. Maternal levels of dichlorodiphenyl-dichloroethylene (DDE) may increase weight and body mass index in adult female offspring. Occup Environ Med. 2009; 66:143-149. [PubMed: 19060027]

190. Kedderis LB, Mills JJ, Andersen ME, Birnbaum LS. A physiologically based pharmacokinetic model for 2,3,7,8-tetrabromodibenzo-p-dioxin (TBDD) in the rat: tissue distribution and CYP1A induction. Toxicol Appl Pharmacol. 1993; 121:87-98. [PubMed: 8337704]

191. Kelce WR, Stone CR, Laws SC, Gray LE, Kemppainen JA, Wilson EM. Persistent DDT metabolite $\mathrm{p}, \mathrm{p}^{\prime}$-DDE is a potent androgen receptor antagonist. Nature. 1995; 375:581-585. [PubMed: 7791873]

192. Kelishadi R, Poursafa P, Jamshidi F. Role of environmental chemicals in obesity: a systematic review on the current evidence. J Environ Public Health. 2013; 2013:896789. [PubMed: 23840234]

193. Kelly BC, Ikonomou MG, Blair JD, Morin AE, Gobas FA. Food web-specific biomagnification of persistent organic pollutants. Science. 2007; 317:236-239. [PubMed: 17626882]

194. Kerley-Hamilton JS, Trask HW, Ridley CJ, Dufour E, Ringelberg CS, Nurinova N, Wong D, Moodie KL, Shipman SL, Moore JH, Korc M, Shworak NW, Tomlinson CR. Obesity is mediated by differential aryl hydrocarbon receptor signaling in mice fed a Western diet. Environ Health Perspect. 2012; 120:1252-1259. [PubMed: 22609946]

195. Kern PA, Dicker-Brown A, Said ST, Kennedy R, Fonseca VA. The stimulation of tumor necrosis factor and inhibition of glucose transport and lipoprotein lipase in adipose cells by $2,3,7,8$ tetrachlorodibenzo-p-dioxin. Metabolism. 2002; 51:65-68. [PubMed: 11782874]

196. Kern PA, Ranganathan S, Li C, Wood L, Ranganathan G. Adipose tissue tumor necrosis factor and interleukin-6 expression in human obesity and insulin resistance. Am J Physiol Endocrinol Metab. 2001; 280:E745-751. [PubMed: 11287357]

197. Kim HW, Kam S, Lee DH. Synergistic interaction between polycyclic aromatic hydrocarbons and environmental tobacco smoke on the risk of obesity in children and adolescents: The U.S. National Health and Nutrition Examination Survey 2003-2008. Environ Res. 2014; 135:354360. [PubMed: 25462685]

198. Kim HW, Song WJ, Li Q, Han SM, Jeon KO, Park SC, Ryu MO, Chae HK, Kyeong K, Youn HY. Canine adipose tissue-derived mesenchymal stem cells ameliorate severe acute pancreatitis by regulating T cells in rats. J Vet Sci. 2016

199. Kim JH, Park HY, Bae S, Lim YH, Hong YC. Diethylhexyl phthalates is associated with insulin resistance via oxidative stress in the elderly: a panel study. PLoS One. 2013; 8:e71392. [PubMed: 23977034]

200. Kim JS, Lim HS, Cho SI, Cheong HK, Lim MK. Impact of Agent Orange exposure among Korean Vietnam veterans. Ind Health. 2003; 41:149-157. [PubMed: 12916744]

201. Kim K, Park H. Association between urinary concentrations of bisphenol A and type 2 diabetes in Korean adults: a population-based cross-sectional study. Int J Hyg Environ Health. 2013; 216:467-471. [PubMed: 22921714]

202. Kim MJ, Marchand P, Henegar C, Antignac JP, Alili R, Poitou C, Bouillot JL, Basdevant A, Le Bizec B, Barouki R, Clément K. Fate and complex pathogenic effects of dioxins and 
polychlorinated biphenyls in obese subjects before and after drastic weight loss. Environ Health Perspect. 2011; 119:377-383. [PubMed: 21156398]

203. Kim MJ, Pelloux V, Guyot E, Tordjman J, Bui LC, Chevallier A, Forest C, Benelli C, Clement K, Barouki R. Inflammatory pathway genes belong to major targets of persistent organic pollutants in adipose cells. Environ Health Perspect. 2012; 120:508-514. [PubMed: 22262711]

204. Kim MJ, Pelloux V, Guyot E, Tordjman J, Bui LC, Chevallier A, Forest C, Benelli C, Clément K, Barouki R. Inflammatory pathway genes belong to major targets of persistent organic pollutants in adipose cells. Environ Health Perspect. 2012; 120:508-514. [PubMed: 22262711]

205. Kohan AB, Vandersall AE, Yang Q, Xu M, Jandacek RJ, Tso P. The transport of DDT from chylomicrons to adipocytes does not mimic triacylglycerol transport. Biochim Biophys Acta. 2013; 1831:300-305. [PubMed: 22885168]

206. Kohlmeier L, Kohlmeier M. Adipose tissue as a medium for epidemiologic exposure assessment. Environ Health Perspect. 1995; 103(Suppl 3):99-106.

207. Korbel L, Spencer JD. Diabetes mellitus and infection: an evaluation of hospital utilization and management costs in the United States. Journal of diabetes and its complications. 2015; 29:192195. [PubMed: 25488325]

208. Kramer HJ, Drenth H, vandenBerg M, Seinen W, DeJongh J. Physiologically based pharmacokinetic model for tetrachlorobenzyltoluenes in rat: comparison of in vitro and in vivo metabolic rates. Toxicol Sci. 2001; 63:22-28. [PubMed: 11509740]

209. Kuiper GG, Shughrue PJ, Merchenthaler I, Gustafsson JA. The estrogen receptor beta subtype: a novel mediator of estrogen action in neuroendocrine systems. Front Neuroendocrinol. 1998; 19:253-286. [PubMed: 9799586]

210. Kumar KS, Kannan K, Paramasivan ON, Shanmuga Sundaram VP, Nakanishi J, Masunaga S. Polychlorinated dibenzo-p-dioxins, dibenzofurans, and polychlorinated biphenyls in human tissues, meat, fish, and wildlife samples from India. Environ Sci Technol. 2001; 35:3448-3455. [PubMed: 11563645]

211. Kuramochi H, Kawamoto K, Miyazaki K, Nagahama K, Maeda K, Li XW, Shibata E, Nakamura T, Sakai S. Determination of physicochemical properties of tetrabromobisphenol A. Environ Toxicol Chem. 2008; 27:2413-2418. [PubMed: 18613742]

212. La Merrill M, Birnbaum LS. Childhood obesity and environmental chemicals. Mt Sinai J Med. 2011; 78:22-48. [PubMed: 21259261]

213. La Merrill M, Emond C, Kim MJ, Antignac JP, Le Bizec B, Clément K, Birnbaum LS, Barouki R. Toxicological function of adipose tissue: focus on persistent organic pollutants. Environ Health Perspect. 2013; 121:162-169. [PubMed: 23221922]

214. Lamb MR, Taylor S, Liu X, Wolff MS, Borrell L, Matte TD, Susser ES, Factor-Litvak P. Prenatal exposure to polychlorinated biphenyls and postnatal growth: a structural analysis. Environ Health Perspect. 2006; 114:779-785. [PubMed: 16675437]

215. Lamichhane DK, Leem JH, Kim HC, Lee JY, Park MS, Jung DY, Ko JK, Ha M, Kim Y, Hong YC, Ha EH. Impact of prenatal exposure to polycyclic aromatic hydrocarbons from maternal diet on birth outcomes: a birth cohort study in Korea. Public Health Nutr. 2016; 19:2562-2571. [PubMed: 27056033]

216. Lang IA, Galloway TS, Scarlett A, Henley WE, Depledge M, Wallace RB, Melzer D. Association of urinary bisphenol A concentration with medical disorders and laboratory abnormalities in adults. JAMA. 2008; 300:1303-1310. [PubMed: 18799442]

217. Langer P, Kocan A, Tajtakova M, Koska J, Radikova Z, Ksinantova L, Imrich R, Huckova M, Drobna B, Gasperikova D, Sebokova E, Klimes I. Increased thyroid volume, prevalence of thyroid antibodies and impaired fasting glucose in young adults from organochlorine cocktail polluted area: outcome of transgenerational transmission? Chemosphere. 2008; 73:1145-1150. [PubMed: 18790515]

218. Langer P, Ukropec J, Kocan A, Drobna B, Radikova Z, Huckova M, Imrich R, Gasperikova D, Klimes I, Trnovec T. Obesogenic and diabetogenic impact of high organochlorine levels (HCB, p,p'-DDE, PCBs) on inhabitants in the highly polluted Eastern Slovakia. Endocr Regul. 2014; 48:17-24. [PubMed: 24524372] 
219. Lanting CI, Huisman M, Muskiet FA, van der Paauw CG, Essed CE, Boersma ER. Polychlorinated biphenyls in adipose tissue, liver, and brain from nine stillborns of varying gestational ages. Pediatr Res. 1998; 44:222-225. [PubMed: 9702918]

220. le Maire A, Bourguet W, Balaguer P. A structural view of nuclear hormone receptor: endocrine disruptor interactions. Cell Mol Life Sci. 2010; 67:1219-1237. [PubMed: 20063036]

221. le Maire A, Grimaldi M, Roecklin D, Dagnino S, Vivat-Hannah V, Balaguer P, Bourguet W. Activation of RXR-PPAR heterodimers by organotin environmental endocrine disruptors. EMBO Rep. 2009; 10:367-373. [PubMed: 19270714]

222. Lee DH, Lee IK, Jin SH, Steffes M, Jacobs DR Jr. Association between serum concentrations of persistent organic pollutants and insulin resistance among nondiabetic adults: results from the National Health and Nutrition Examination Survey 1999-2002. Diabetes Care. 2007; 30:622628. [PubMed: 17327331]

223. Lee DH, Lee IK, Porta M, Steffes M, Jacobs DR Jr. Relationship between serum concentrations of persistent organic pollutants and the prevalence of metabolic syndrome among non-diabetic adults: results from the National Health and Nutrition Examination Survey 1999-2002. Diabetologia. 2007; 50:1841-1851. [PubMed: 17624515]

224. Lee DH, Lee IK, Song K, Steffes M, Toscano W, Baker BA, Jacobs DR Jr. A strong doseresponse relation between serum concentrations of persistent organic pollutants and diabetes: results from the National Health and Examination Survey 1999-2002. Diabetes Care. 2006; 29:1638-1644. [PubMed: 16801591]

225. Lee DH, Lee IK, Steffes M, Jacobs DR Jr. Extended analyses of the association between serum concentrations of persistent organic pollutants and diabetes. Diabetes Care. 2007; 30:1596-1598. [PubMed: 17363745]

226. Lee DH, Lind L, Jacobs DR Jr, Salihovic S, van Bavel B, Lind PM. Associations of persistent organic pollutants with abdominal obesity in the elderly: The Prospective Investigation of the Vasculature in Uppsala Seniors (PIVUS) study. Environ Int. 2012; 40:170-178. [PubMed: 21835469]

227. Lee DH, Lind PM, Jacobs DR Jr, Salihovic S, van Bavel B, Lind L. Polychlorinated biphenyls and organochlorine pesticides in plasma predict development of type 2 diabetes in the elderly: the prospective investigation of the vasculature in Uppsala Seniors (PIVUS) study. Diabetes Care. 2011; 34:1778-1784. [PubMed: 21700918]

228. Lee DH, Porta M, Jacobs DR Jr, Vandenberg LN. Chlorinated persistent organic pollutants, obesity, and type 2 diabetes. Endocr Rev. 2014; 35:557-601. [PubMed: 24483949]

229. Lee DH, Steffes MW, Sjodin A, Jones RS, Needham LL, Jacobs DR Jr. Low dose of some persistent organic pollutants predicts type 2 diabetes: a nested case-control study. Environ Health Perspect. 2010; 118:1235-1242. [PubMed: 20444671]

230. Lee DH, Steffes MW, Sjodin A, Jones RS, Needham LL, Jacobs DR Jr. Low dose organochlorine pesticides and polychlorinated biphenyls predict obesity, dyslipidemia, and insulin resistance among people free of diabetes. PLoS One. 2011; 6:e15977. [PubMed: 21298090]

231. Lerch S, Guidou C, Thome JP, Jurjanz S. Non-dioxin-like Polychlorinated Biphenyls (PCBs) and Chlordecone Release from Adipose Tissue to Blood in Response to Body Fat Mobilization in Ewe (Ovis aries). J Agric Food Chem. 2016; 64:1212-1220. [PubMed: 26761077]

232. Levitt DG. Quantitative relationship between the octanol/water partition coefficient and the diffusion limitation of the exchange between adipose and blood. BMC Clin Pharmacol. 2010; 10:1. [PubMed: 20055995]

233. Lewis RG, Sovocool GW. Identification of polybrominated biphenyls in the adipose tissues of the general population of the United States. J Anal Toxicol. 1982; 6:196-198. [PubMed: 6289008]

234. Li C, Ford ES, Zhao G, Mokdad AH. Prevalence of pre-diabetes and its association with clustering of cardiometabolic risk factors and hyperinsulinemia among U.S. adolescents: National Health and Nutrition Examination Survey 2005-2006. Diabetes Care. 2009; 32:342347. [PubMed: 18957533]

235. Li W, Vogel CF, Matsumura F. Studies on the cell treatment conditions to elicit lipolytic responses from 3T3-L1 adipocytes to TCDD, 2,3,7,8-tetrachlorodibenzo-p-dioxin. J Cell Biochem. 2007; 102:389-402. [PubMed: 17407152] 
236. Li X, Ycaza J, Blumberg B. The environmental obesogen tributyltin chloride acts via peroxisome proliferator activated receptor gamma to induce adipogenesis in murine 3T3-L1 preadipocytes. $\mathrm{J}$ Steroid Biochem Mol Biol. 2011; 127:9-15. [PubMed: 21397693]

237. Lihn AS, Pedersen SB, Richelsen B. Adiponectin: action, regulation and association to insulin sensitivity. Obes Rev. 2005; 6:13-21. [PubMed: 15655035]

238. Lilienthal H, Hack A, Roth-Harer A, Grande SW, Talsness CE. Effects of developmental exposure to 2,2, 4,4, 5-pentabromodiphenyl ether (PBDE-99) on sex steroids, sexual development, and sexually dimorphic behavior in rats. Environ Health Perspect. 2006; 114:194-201. [PubMed: 16451854]

239. Lim JS, Lee DH, Jacobs DR Jr. Association of brominated flame retardants with diabetes and metabolic syndrome in the U.S. population, 2003-2004. Diabetes Care. 2008; 31:1802-1807. [PubMed: 18559655]

240. Lim JS, Son HK, Park SK, Jacobs DR, Lee DH. Inverse associations between long-term weight change and serum concentrations of persistent organic pollutants. Int J Obes (Lond). 2011; 35:744-747. [PubMed: 20820170]

241. Lind PM, Lee DH, Jacobs DR, Salihovic S, van Bavel B, Wolff MS, Lind L. Circulating levels of persistent organic pollutants are related to retrospective assessment of life-time weight change. Chemosphere. 2013; 90:998-1004. [PubMed: 22921642]

242. Lindberg P, Sellström U, Häggberg L, de Wit CA. Higher brominated diphenyl ethers and hexabromocyclododecane found in eggs of peregrine falcons (Falco peregrinus) breeding in Sweden. Environ Sci Technol. 2004; 38:93-96. [PubMed: 14740722]

243. Ljunggren SA, Helmfrid I, Salihovic S, van Bavel B, Wingren G, Lindahl M, Karlsson H. Persistent organic pollutants distribution in lipoprotein fractions in relation to cardiovascular disease and cancer. Environ Int. 2014; 65:93-99. [PubMed: 24472825]

244. Lobstein T, Frelut ML. Prevalence of overweight among children in Europe. Obes Rev. 2003; 4:195-200. [PubMed: 14649370]

245. Lohmann R, Breivik K, Dachs J, Muir D. Global fate of POPs: current and future research directions. Environ Pollut. 2007; 150:150-165. [PubMed: 17698265]

246. Longnecker MP, Klebanoff MA, Brock JW, Zhou H, Collaborative Perinatal P. Polychlorinated biphenyl serum levels in pregnant subjects with diabetes. Diabetes Care. 2001; 24:1099-1101. [PubMed: 11375377]

247. Longnecker MP, Michalek JE. Serum dioxin level in relation to diabetes mellitus among Air Force veterans with background levels of exposure. Epidemiology. 2000; 11:44-48. [PubMed: 10615842]

248. Lopez-Espinosa MJ, Murcia M, Iniguez C, Vizcaino E, Llop S, Vioque J, Grimalt JO, Rebagliato M, Ballester F. Prenatal exposure to organochlorine compounds and birth size. Pediatrics. 2011; 128:e127-134. [PubMed: 21669889]

249. Louis C, Covaci A, Crocker DE, Debier C. Lipophilicity of PCBs and fatty acids determines their mobilisation from blubber of weaned northern elephant seal pups. Sci Total Environ. 2016; 541:599-602. [PubMed: 26439651]

250. Louis C, Dirtu AC, Stas M, Guiot Y, Malarvannan G, Das K, Costa DP, Crocker DE, Covaci A, Debier C. Mobilisation of lipophilic pollutants from blubber in northern elephant seal pups (Mirounga angustirostris) during the post-weaning fast. Environ Res. 2014; 132:438-448. [PubMed: 24858284]

251. Ludwicki JK, Góralczyk K. Organochlorine pesticides and PCBs in human adipose tissues in Poland. Bull Environ Contam Toxicol. 1994; 52:400-403. [PubMed: 8142711]

252. Lundén A, Norén K. Polychlorinated naphthalenes and other organochlorine contaminants in Swedish human milk, 1972-1992. Arch Environ Contam Toxicol. 1998; 34:414-423. [PubMed: 9543513]

253. Mabey WR, Smith JH, Podoll RT, Johnson HL, Mill T, Chou T-W, Gates J, Waight Partridge I, Jaber H, Vandenberg D. Aquatic Fate Process Data for Organic Priority Pollutants. Standards. MaDSDOoWRa. , editorWashington, D.C.: Environmental Protection Agency; 1981. 
254. MacGregor JA, Nixon WB. Hexabromocyclododecane (HBCD): Determination of n-Octanol/ Water Partition Coefficient. Arlington, VA: Wildlife International LTD; 1997. Project No. 439C-104

255. Maffeis C, Tato L. Long-term effects of childhood obesity on morbidity and mortality. Horm Res. 2001; 55(Suppl 1):42-45. [PubMed: 11408761]

256. Malarvannan G, Dirinck E, Dirtu AC, Pereira-Fernandes A, Neels H, Jorens PG, Gaal LV, Blust R, Covaci A. Distribution of persistent organic pollutants in two different fat compartments from obese individuals. Environ Int. 2013; 55:33-42. [PubMed: 23518385]

257. Marette A. Molecular mechanisms of inflammation in obesity-linked insulin resistance. Int J Obes Relat Metab Disord. 2003; 27(Suppl 3):S46-48. [PubMed: 14704744]

258. Masuno H, Iwanami J, Kidani T, Sakayama K, Honda K. Bisphenol a accelerates terminal differentiation of 3T3-L1 cells into adipocytes through the phosphatidylinositol 3-kinase pathway. Toxicol Sci. 2005; 84:319-327. [PubMed: 15659569]

259. McConnachie PR, Zahalsky AC. Immunological consequences of exposure to pentachlorophenol. Arch Environ Health. 1991; 46:249-253. [PubMed: 2069434]

260. McConnell R, Gilliland FD, Goran M, Allayee H, Hricko A, Mittelman S. Does near-roadway air pollution contribute to childhood obesity? Pediatr Obes. 2016; 11:1-3. [PubMed: 25820202]

261. McDonald M. NTP technical report on the toxicity studies of Pentachlorobenzene in F344/N Rats and B6C3F1 Mice (Feed Studies) (CAS No. 608-93-5). Toxic Rep Ser. 1991; 6:1-48. [PubMed: 12209162]

262. Meeker JD, Sathyanarayana S, Swan SH. Phthalates and other additives in plastics: human exposure and associated health outcomes. Philos Trans R Soc Lond B Biol Sci. 2009; 364:20972113. [PubMed: 19528058]

263. Melzer D, Rice NE, Lewis C, Henley WE, Galloway TS. Association of urinary bisphenol a concentration with heart disease: evidence from NHANES 2003/06. PLoS One. 2010; 5:e8673. [PubMed: 20084273]

264. Menale C, Grandone A, Nicolucci C, Cirillo G, Crispi S, Di Sessa A, Marzuillo P, Rossi S, Mita DG, Perrone L, Diano N, Miraglia Del Giudice E. Bisphenol A is associated with insulin resistance and modulates adiponectin and resistin gene expression in obese children. Pediatr Obes. 2016

265. Mendez MA, Garcia-Esteban R, Guxens M, Vrijheid M, Kogevinas M, Goni F, Fochs S, Sunyer J. Prenatal organochlorine compound exposure, rapid weight gain, and overweight in infancy. Environ Health Perspect. 2011; 119:272-278. [PubMed: 20923745]

266. Mensah GA, Brown DW. An overview of cardiovascular disease burden in the United States. Health affairs. 2007; 26:38-48. [PubMed: 17211012]

267. Mes J, Davies DJ, Turton D. Polychlorinated biphenyl and other chlorinated hydrocarbon residues in adipose tissue of Canadians. Bull Environ Contam Toxicol. 1982; 28:97-104. [PubMed: 6802207]

268. Meylan WM, Howard PH. Atom/fragment contribution method for estimating octanol-water partition coefficients. J Pharm Sci. 1995; 84:83-92. [PubMed: 7714751]

269. Miao M, Yuan W, Zhu G, He X, Li DK. In utero exposure to bisphenol-A and its effect on birth weight of offspring. Reprod Toxicol. 2011; 32:64-68. [PubMed: 21440056]

270. Miceli JN, Nolan DC, Marks B, Hariharan M. Persistence of polybrominated biphenyls (PBB) in human post-mortem tissue. Environ Health Perspect. 1985; 60:399-403. [PubMed: 2992925]

271. Mitsuhashi K, Senmaru T, Fukuda T, Yamazaki M, Shinomiya K, Ueno M, Kinoshita S, Kitawaki J, Katsuyama M, Tsujikawa M, Obayashi H, Nakamura N, Fukui M. Testosterone stimulates glucose uptake and GLUT4 translocation through LKB1/AMPK signaling in 3T3-L1 adipocytes. Endocrine. 2016; 51:174-184. [PubMed: 26100787]

272. Miyawaki J, Sakayama K, Kato H, Yamamoto H, Masuno H. Perinatal and postnatal exposure to bisphenol a increases adipose tissue mass and serum cholesterol level in mice. J Atheroscler Thromb. 2007; 14:245-252. [PubMed: 17938543]

273. Mokdad AH, Ford ES, Bowman BA, Dietz WH, Vinicor F, Bales VS, Marks JS. Prevalence of obesity, diabetes, and obesity-related health risk factors, 2001. JAMA. 2003; 289:76-79. [PubMed: 12503980] 
274. Mokdad AH, Serdula MK, Dietz WH, Bowman BA, Marks JS, Koplan JP. The spread of the obesity epidemic in the United States, 1991-1998. JAMA. 1999; 282:1519-1522. [PubMed: 10546690]

275. Montague CT, O'Rahilly S. The perils of portliness: causes and consequences of visceral adiposity. Diabetes. 2000; 49:883-888. [PubMed: 10866038]

276. Montgomery MP, Kamel F, Saldana TM, Alavanja MC, Sandler DP. Incident diabetes and pesticide exposure among licensed pesticide applicators: Agricultural Health Study, 1993-2003. Am J Epidemiol. 2008; 167:1235-1246. [PubMed: 18343878]

277. Moon HB, Lee DH, Lee YS, Kannan K. Occurrence and accumulation patterns of polycyclic aromatic hydrocarbons and synthetic musk compounds in adipose tissues of Korean females. Chemosphere. 2012; 86:485-490. [PubMed: 22055311]

278. Moreno-Aliaga MJ, Matsumura F. Effects of 1,1,1-trichloro-2,2-bis(p-chlorophenyl)-ethane (p,p' DDT) on 3T3-L1 and 3T3-F442A adipocyte differentiation. Biochem Pharmacol. 2002; 63:9971007. [PubMed: 11911853]

279. Morgan DP, Roan CC, Paschal EH. Transport of DDT, DDE, and dieldrin in human blood. Bull Environ Contam Toxicol. 1972; 8:321-326. [PubMed: 4669503]

280. Moriyama K, Tagami T, Akamizu T, Usui T, Saijo M, Kanamoto N, Hataya Y, Shimatsu A, Kuzuya $\mathrm{H}$, Nakao K. Thyroid hormone action is disrupted by bisphenol A as an antagonist. J Clin Endocrinol Metab. 2002; 87:5185-5190. [PubMed: 12414890]

281. Morris S, Allchin CR, Zegers BN, Haftka JJ, Boon JP, Belpaire C, Leonards PE, Van Leeuwen SP, De Boer J. Distribution and fate of HBCD and TBBPA brominated flame retardants in North Sea estuaries and aquatic food webs. Environ Sci Technol. 2004; 38:5497-5504. [PubMed: 15575264]

282. Muir DCG, Segstro MD, Welbourn PM, Toom D, Eisenreich SJ, Macdonald CR, Whelpdale DM. Patterns of accumulation of airborne organochlorine contaminants in lichens from the upper Great Lakes region of Ontario. Environmental Science and Technology. 1993; 27:1201-1210.

283. Müllerová D, Matějková D, Dvořáková J, Müller L, Rosmus J, Kovářová K. PERSISTENT ORGANOCHLORINE POLLUTANTS IN OBESE WOMEN AFTER DIET INDUCED WEIGHT LOSS: FIVE YEARS FOLLOW UP STUDY. Cent Eur J Public Health. 2015; 23:214217. [PubMed: 26615652]

284. Murphy LE, Gollenberg AL, Buck Louis GM, Kostyniak PJ, Sundaram R. Maternal serum preconception polychlorinated biphenyl concentrations and infant birth weight. Environ Health Perspect. 2010; 118:297-302. [PubMed: 20123616]

285. Must A, Jacques PF, Dallal GE, Bajema CJ, Dietz WH. Long-term morbidity and mortality of overweight adolescents. A follow-up of the Harvard Growth Study of 1922 to 1935. N Engl J Med. 1992; 327:1350-1355. [PubMed: 1406836]

286. Nair A, Dureja P, Pillai MK. Aldrin and dieldrin residues in human fat, milk and blood serum collected from Delhi. Hum Exp Toxicol. 1992; 11:43-45. [PubMed: 1354459]

287. Neely WB, Branson DR, Blau GE. Partition coefficient to measure bioconcentration potential of organic chemicals in fish. Environmental Science and Technology. 1974; 8:1113-1115.

288. Neff JM. Bioaccumulation in Marine Organisms: Effect of Contaminants from Oil Well Produced Water. Elsevier Science; 2002. 468

289. Newbold RR, Padilla-Banks E, Jefferson WN, Heindel JJ. Effects of endocrine disruptors on obesity. Int J Androl. 2008; 31:201-208. [PubMed: 18315718]

290. Newbold RR, Padilla-Banks E, Snyder RJ, Jefferson WN. Perinatal exposure to environmental estrogens and the development of obesity. Mol Nutr Food Res. 2007; 51:912-917. [PubMed: 17604389]

291. Nishimura N, Miyabara Y, Sato M, Yonemoto J, Tohyama C. Immunohistochemical localization of thyroid stimulating hormone induced by a low oral dose of 2,3,7,8-tetrachlorodibenzo-pdioxin in female Sprague-Dawley rats. Toxicology. 2002; 171:73-82. [PubMed: 11836014]

292. Nishiumi S, Yoshida M, Azuma T, Yoshida K, Ashida H. 2,3,7,8-tetrachlorodibenzo-p-dioxin impairs an insulin signaling pathway through the induction of tumor necrosis factor-alpha in adipocytes. Toxicol Sci. 2010; 115:482-491. [PubMed: 20181658] 
293. Obana H, Hori S, Kashimoto T, Kunita N. Polycyclic aromatic hydrocarbons in human fat and liver. Bull Environ Contam Toxicol. 1981; 27:23-27. [PubMed: 7296033]

294. Oberg M, Sjödin A, Casabona H, Nordgren I, Klasson-Wehler E, Håkansson H. Tissue distribution and half-lives of individual polychlorinated biphenyls and serum levels of 4hydroxy-2,3,3' $, 4^{\prime}, 5$-pentachlorobiphenyl in the rat. Toxicol Sci. 2002; 70:171-182. [PubMed: 12441362]

295. Ode A, Källén K, Gustafsson P, Rylander L, Jönsson BA, Olofsson P, Ivarsson SA, Lindh CH, Rignell-Hydbom A. Fetal exposure to perfluorinated compounds and attention deficit hyperactivity disorder in childhood. PLoS One. 2014; 9:e95891. [PubMed: 24760015]

296. Ogden CL, Carroll MD, Curtin LR, McDowell MA, Tabak CJ, Flegal KM. Prevalence of overweight and obesity in the United States, 1999-2004. JAMA. 2006; 295:1549-1555. [PubMed: 16595758]

297. Ohlstein JF, Strong AL, McLachlan JA, Gimble JM, Burow ME, Bunnell BA. Bisphenol A enhances adipogenic differentiation of human adipose stromal/stem cells. J Mol Endocrinol. 2014; 53:345-353. [PubMed: 25143472]

298. Ohtake F, Fujii-Kuriyama Y, Kato S. [Transcription factor AhR is a ligand-dependent E3 ubiquitin ligase]. Tanpakushitsu Kakusan Koso. 2007; 52:1973-1979. [PubMed: 18064888]

299. Ohtake F, Takeyama K, Matsumoto T, Kitagawa H, Yamamoto Y, Nohara K, Tohyama C, Krust A, Mimura J, Chambon P, Yanagisawa J, Fujii-Kuriyama Y, Kato S. Modulation of oestrogen receptor signalling by association with the activated dioxin receptor. Nature. 2003; 423:545-550. [PubMed: 12774124]

300. Oken E, Levitan EB, Gillman MW. Maternal smoking during pregnancy and child overweight: systematic review and meta-analysis. Int J Obes (Lond). 2008; 32:201-210. [PubMed: 18278059]

301. Oliver BG, Niimi AJ. Bioconcentration factors of some halogenated organics for rainbow trout: limitations in their use for prediction of environmental residues. Environ Sci Technol. 1985; 19:842-849. [PubMed: 22196610]

302. Olsen H, Enan E, Matsumura F. 2,3,7,8-Tetrachlorodibenzo-p-dioxin mechanism of action to reduce lipoprotein lipase activity in the 3T3-L1 preadipocyte cell line. J Biochem Mol Toxicol. 1998; 12:29-39. [PubMed: 9414485]

303. Orban JE, Stanley JS, Schwemberger JG, Remmers JC. Dioxins and dibenzofurans in adipose tissue of the general US population and selected subpopulations. Am J Public Health. 1994; 84:439-445. [PubMed: 8129062]

304. Organization WH. Diabetes; Fact sheet 312. 2016

305. Organization WH. Facts and figures on childhood obesity. 2014

306. Organization WH. Obesity and Overweight Fact Sheet No 311. 2016

307. Park MJ, Lee SK, Yang JY, Kim KW, Lee SY, Lee WT, Chung KH, Yun YP, Yoo YC. Distribution of organochlorines and PCB congeners in Korean human tissues. Arch Pharm Res. 2005; 28:829-838. [PubMed: 16114499]

308. Patandin S, Koopman-Esseboom C, de Ridder MA, Weisglas-Kuperus N, Sauer PJ. Effects of environmental exposure to polychlorinated biphenyls and dioxins on birth size and growth in Dutch children. Pediatr Res. 1998; 44:538-545. [PubMed: 9773843]

309. Patterson DGJ, Fürst P, Henderson LO, Isaacs SG, Alexander LR, Turner WE, Needham LL, Hannon H. Partitioning of in vivo bound PCDDs/PCDFs among various compartments in whole blood. Chemosphere. 1989; 19:135-142.

310. Pavuk M, Schecter AJ, Akhtar FZ, Michalek JE. Serum 2,3,7,8-tetrachlorodibenzo-p-dioxin (TCDD) levels and thyroid function in Air Force veterans of the Vietnam War. Ann Epidemiol. 2003; 13:335-343. [PubMed: 12821272]

311. Pedersen SB, Bruun JM, Hube F, Kristensen K, Hauner H, Richelsen B. Demonstration of estrogen receptor subtypes alpha and beta in human adipose tissue: influences of adipose cell differentiation and fat depot localization. Mol Cell Endocrinol. 2001; 182:27-37. [PubMed: 11500236]

312. Pelletier C, Despres JP, Tremblay A. Plasma organochlorine concentrations in endurance athletes and obese individuals. Med Sci Sports Exerc. 2002; 34:1971-1975. [PubMed: 12471304] 
313. Pereira MdS. Polychlorinated dibenzo-p-dioxins (PCDD), dibenzofurans (PCDF) and polychlorinated biphenyls (PCB): main sources, environmental behaviour and risk to man and biota. Química Nova. 2004; 27:934-943.

314. Perera FP, Jedrychowski W, Rauh V, Whyatt RM. Molecular epidemiologic research on the effects of environmental pollutants on the fetus. Environ Health Perspect. 1999; 107(Suppl 3): 451-460. [PubMed: 10346993]

315. Perera FP, Whyatt RM, Jedrychowski W, Rauh V, Manchester D, Santella RM, Ottman R. Recent developments in molecular epidemiology: A study of the effects of environmental polycyclic aromatic hydrocarbons on birth outcomes in Poland. Am J Epidemiol. 1998; 147:309-314. [PubMed: 9482506]

316. Pestana D, Faria G, Sa C, Fernandes VC, Teixeira D, Norberto S, Faria A, Meireles M, Marques C, Correia-Sa L, Cunha A, Guimaraes JT, Taveira-Gomes A, Santos AC, Domingues VF, Delerue-Matos C, Monteiro R, Calhau C. Persistent organic pollutant levels in human visceral and subcutaneous adipose tissue in obese individuals-depot differences and dysmetabolism implications. Environ Res. 2014; 133:170-177. [PubMed: 24949816]

317. Pestana D, Faria G, Sá C, Fernandes VC, Teixeira D, Norberto S, Faria A, Meireles M, Marques C, Correia-Sá L, Cunha A, Guimarães JT, Taveira-Gomes A, Santos AC, Domingues VF, Delerue-Matos C, Monteiro R, Calhau C. Persistent organic pollutant levels in human visceral and subcutaneous adipose tissue in obese individuals-depot differences and dysmetabolism implications. Environ Res. 2014; 133:170-177. [PubMed: 24949816]

318. Peterson SH, Peterson MG, Debier C, Covaci A, Dirtu AC, Malarvannan G, Crocker DE, Schwarz LK, Costa DP. Deep-ocean foraging northern elephant seals bioaccumulate persistent organic pollutants. Sci Total Environ. 2015; 533:144-155. [PubMed: 26151658]

319. Petreas M, Smith D, Hurley S, Jeffrey SS, Gilliss D, Reynolds P. Distribution of persistent, lipidsoluble chemicals in breast and abdominal adipose tissues: lessons learned from a breast cancer study. Cancer Epidemiol Biomarkers Prev. 2004; 13:416-424. [PubMed: 15006918]

320. Phillips M, Enan E, Liu PC, Matsumura F. Inhibition of 3T3-L1 adipose differentiation by 2,3,7,8-tetrachlorodibenzo-p-dioxin. J Cell Sci. 1995; 108(Pt 1):395-402. [PubMed: 7537747]

321. Pitteloud N, Mootha VK, Dwyer AA, Hardin M, Lee H, Eriksson KF, Tripathy D, Yialamas M, Groop L, Elahi D, Hayes FJ. Relationship between testosterone levels, insulin sensitivity, and mitochondrial function in men. Diabetes Care. 2005; 28:1636-1642. [PubMed: 15983313]

322. Poon BH, Leung CK, Wong CK, Wong MH. Polychlorinated biphenyls and organochlorine pesticides in human adipose tissue and breast milk collected in Hong Kong. Arch Environ Contam Toxicol. 2005; 49:274-282. [PubMed: 16001156]

323. Quintana PJ, Delfino RJ, Korrick S, Ziogas A, Kutz FW, Jones EL, Laden F, Garshick E. Adipose tissue levels of organochlorine pesticides and polychlorinated biphenyls and risk of nonHodgkin's lymphoma. Environ Health Perspect. 2004; 112:854-861. [PubMed: 15175172]

324. Ranjbar M, Rotondi MA, Ardern CI, Kuk JL. Urinary Biomarkers of Polycyclic Aromatic Hydrocarbons Are Associated with Cardiometabolic Health Risk. PLoS One. 2015; 10:e0137536. [PubMed: 26340343]

325. Richter CA, Birnbaum LS, Farabollini F, Newbold RR, Rubin BS, Talsness CE, Vandenbergh JG, Walser-Kuntz DR, vom Saal FS. In vivo effects of bisphenol A in laboratory rodent studies. Reprod Toxicol. 2007; 24:199-224. [PubMed: 17683900]

326. Rignell-Hydbom A, Elfving M, Ivarsson SA, Lindh C, Jonsson BA, Olofsson P, Rylander L. A nested case-control study of intrauterine exposure to persistent organochlorine pollutants in relation to risk of type 1 diabetes. PLoS One. 2010; 5:e11281. [PubMed: 20585661]

327. Ritter L, Solomon KR, Forget J, Stemeroff M, O'Leary C. A review of selected persistent organic pollutants DDT-Aldrin-Dieldrin-Endrin-Chlordane-Heptachlor-Hexachlorobenzene-MirexToxaphene-Polychorintaed biphenyls-Dioxins and Furans. Canada: 1995.

328. Riu A, Grimaldi M, le Maire A, Bey G, Phillips K, Boulahtouf A, Perdu E, Zalko D, Bourguet W, Balaguer P. Peroxisome proliferator-activated receptor gamma is a target for halogenated analogs of bisphenol A. Environ Health Perspect. 2011; 119:1227-1232. [PubMed: 21561829]

329. Riu A, le Maire A, Grimaldi M, Audebert M, Hillenweck A, Bourguet W, Balaguer P, Zalko D. Characterization of novel ligands of ERalpha, Erbeta, and PPARgamma: the case of halogenated 
bisphenol A and their conjugated metabolites. Toxicol Sci. 2011; 122:372-382. [PubMed: 21622942]

330. Robinson PE, Leczynski BA, Kutz FW, Remmers JC. An evaluation of hexachlorobenzene bodyburden levels in the general population of the USA. IARC Sci Publ. 1986:183-192.

331. Ronen Z, Abeliovich A. Anaerobic-aerobic process for microbial degradation of tetrabromobisphenol A. Appl Environ Microbiol. 2000; 66:2372-2377. [PubMed: 10831413]

332. Ronn M, Lind L, van Bavel B, Salihovic S, Michaelsson K, Lind PM. Circulating levels of persistent organic pollutants associate in divergent ways to fat mass measured by DXA in humans. Chemosphere. 2011; 85:335-343. [PubMed: 21767864]

333. Roos V, Ronn M, Salihovic S, Lind L, van Bavel B, Kullberg J, Johansson L, Ahlstrom H, Lind PM. Circulating levels of persistent organic pollutants in relation to visceral and subcutaneous adipose tissue by abdominal MRI. Obesity (Silver Spring). 2013; 21:413-418. [PubMed: 23532994]

334. Roy JR, Chakraborty S, Chakraborty TR. Estrogen-like endocrine disrupting chemicals affecting puberty in humans-a review. Med Sci Monit. 2009; 15:RA137-145. [PubMed: 19478717]

335. Rundle A, Hoepner L, Hassoun A, Oberfield S, Freyer G, Holmes D, Reyes M, Quinn J, Camann D, Perera F, Whyatt R. Association of childhood obesity with maternal exposure to ambient air polycyclic aromatic hydrocarbons during pregnancy. Am J Epidemiol. 2012; 175:1163-1172. [PubMed: 22505764]

336. Ruzzin J, Petersen R, Meugnier E, Madsen L, Lock EJ, Lillefosse H, Ma T, Pesenti S, Sonne SB, Marstrand TT, Malde MK, Du ZY, Chavey C, Fajas L, Lundebye AK, Brand CL, Vidal H, Kristiansen K, Froyland L. Persistent organic pollutant exposure leads to insulin resistance syndrome. Environ Health Perspect. 2010; 118:465-471. [PubMed: 20064776]

337. Rylander L, Rignell-Hydbom A, Hagmar L. A cross-sectional study of the association between persistent organochlorine pollutants and diabetes. Environ Health. 2005; 4:28. [PubMed: 16316471]

338. Sabljic A. On the prediction of soil sorption coefficients of organic pollutants from molecular structure: application of molecular topology model. Environ Sci Technol. 1987; 21:358-366. [PubMed: 22280175]

339. Safe S. Polychlorinated biphenyls (PCBs), dibenzo-p-dioxins (PCDDs), dibenzofurans (PCDFs), and related compounds: environmental and mechanistic considerations which support the development of toxic equivalency factors (TEFs). Crit Rev Toxicol. 1990; 21:51-88. [PubMed: 2124811]

340. Safe S, Wormke M. Inhibitory aryl hydrocarbon receptor-estrogen receptor alpha cross-talk and mechanisms of action. Chem Res Toxicol. 2003; 16:807-816. [PubMed: 12870882]

341. Sbarbati A, Accorsi D, Benati D, Marchetti L, Orsini G, Rigotti G, Panettiere P. Subcutaneous adipose tissue classification. Eur J Histochem. 2010; 54:e48. [PubMed: 21263747]

342. Schecter A, Pavuk M, Päpke O, Ryan JJ, Birnbaum L, Rosen R. Polybrominated diphenyl ethers (PBDEs) in U.S. mothers' milk. Environ Health Perspect. 2003; 111:1723-1729. [PubMed: 14594622]

343. Schildkraut JM, Demark-Wahnefried W, DeVoto E, Hughes C, Laseter JL, Newman B. Environmental contaminants and body fat distribution. Cancer Epidemiol Biomarkers Prev. 1999; 8:179-183. [PubMed: 10067817]

344. Schrader TJ, Cooke GM. Effects of Aroclors and individual PCB congeners on activation of the human androgen receptor in vitro. Reprod Toxicol. 2003; 17:15-23. [PubMed: 12507654]

345. Schwarzenbach RP, Gschwend PM, Imboden DM. Environmental Organic Chemistry. John Wiley \& Sons, Inc; 2003.

346. Scinicariello F, Buser MC. Urinary polycyclic aromatic hydrocarbons and childhood obesity: NHANES (2001-2006). Environ Health Perspect. 2014; 122:299-303. [PubMed: 24380973]

347. Seale P, Lazar MA. Brown fat in humans: turning up the heat on obesity. Diabetes. 2009; 58:1482-1484. [PubMed: 19564460]

348. Seefeld MD, Corbett SW, Keesey RE, Peterson RE. Characterization of the wasting syndrome in rats treated with 2,3,7,8-tetrachlorodibenzo-p-dioxin. Toxicol Appl Pharmacol. 1984; 73:311322. [PubMed: 6710531] 
349. Shankar A, Teppala S. Relationship between urinary bisphenol A levels and diabetes mellitus. J Clin Endocrinol Metab. 2011; 96:3822-3826. [PubMed: 21956417]

350. Shanle EK, Xu W. Endocrine disrupting chemicals targeting estrogen receptor signaling: identification and mechanisms of action. Chem Res Toxicol. 2011; 24:6-19. [PubMed: 21053929]

351. Sharman M, Read WA, Castle L, Gilbert J. Levels of di-(2-ethylhexyl)phthalate and total phthalate esters in milk, cream, butter and cheese. Food Addit Contam. 1994; 11:375-385. [PubMed: 7926171]

352. Shaw SD, Berger ML, Brenner D, Kannan K, Lohmann N, Päpke O. Bioaccumulation of polybrominated diphenyl ethers and hexabromocyclododecane in the northwest Atlantic marine food web. Sci Total Environ. 2009; 407:3323-3329. [PubMed: 19269019]

353. Shen H, Han J, Tie X, Xu W, Ren Y, Ye C. Polychlorinated dibenzo-p-dioxins/furans and polychlorinated biphenyls in human adipose tissue from Zhejiang Province, China. Chemosphere. 2009; 74:384-388. [PubMed: 19004467]

354. Shimba S, Todoroki K, Aoyagi T, Tezuka M. Depletion of arylhydrocarbon receptor during adipose differentiation in 3T3-L1 cells. Biochem Biophys Res Commun. 1998; 249:131-137. [PubMed: 9705844]

355. Shiverick KT, Muther TF. Effects of 2,3,7,8-tetrachlorodibenzo-p-dioxin on serum concentrations and the uterotrophic action of exogenous estrone in rats. Toxicol Appl Pharmacol. 1982; 65:170 176. [PubMed: 7147249]

356. Sijm DTHM, Wever H, de Vries PJ, Opperhuizen A. Octan-1-ol/water partition coefficients of polychlorinated dibenzo-p-dioxins and dibenzofurans: Experimental values determined with a stirring method. Chemosphere. 1989; 19:263-266.

357. Silverstone AE, Rosenbaum PF, Weinstock RS, Bartell SM, Foushee HR, Shelton C, Pavuk M. Polychlorinated biphenyl (PCB) exposure and diabetes: results from the Anniston Community Health Survey. Environ Health Perspect. 2012; 120:727-732. [PubMed: 22334129]

358. Sjödin A, Patterson DG, Bergman A. Brominated flame retardants in serum from U.S. blood donors. Environ Sci Technol. 2001; 35:3830-3833. [PubMed: 11642440]

359. Sjödin A, Patterson DG, Bergman A. A review on human exposure to brominated flame retardants-particularly polybrominated diphenyl ethers. Environ Int. 2003; 29:829-839. [PubMed: 12850099]

360. Skogen JC, Overland S. The fetal origins of adult disease: a narrative review of the epidemiological literature. JRSM Short Rep. 2012; 3:59. [PubMed: 23301147]

361. Slotkin TA. Does early-life exposure to organophosphate insecticides lead to prediabetes and obesity? Reprod Toxicol. 2011; 31:297-301. [PubMed: 20850519]

362. Smink A, Ribas-Fito N, Garcia R, Torrent M, Mendez MA, Grimalt JO, Sunyer J. Exposure to hexachlorobenzene during pregnancy increases the risk of overweight in children aged 6 years. Acta Paediatr. 2008; 97:1465-1469. [PubMed: 18665907]

363. Soine PJ, Blanke RV, Guzelian PS, Schwartz CC. Preferential binding of chlordecone to the protein and high density lipoprotein fractions of plasma from humans and other species. J Toxicol Environ Health. 1982; 9:107-118. [PubMed: 6174734]

364. Somm E, Schwitzgebel VM, Toulotte A, Cederroth CR, Combescure C, Nef S, Aubert ML, Huppi PS. Perinatal exposure to bisphenol a alters early adipogenesis in the rat. Environ Health Perspect. 2009; 117:1549-1555. [PubMed: 20019905]

365. Spiegelman BM, Flier JS. Adipogenesis and obesity: rounding out the big picture. Cell. 1996; 87:377-389. [PubMed: 8898192]

366. Spink DC, Eugster HP, Lincoln DW 2nd, Schuetz JD, Schuetz EG, Johnson JA, Kaminsky LS, Gierthy JF. 17 beta-estradiol hydroxylation catalyzed by human cytochrome P450 1A1: a comparison of the activities induced by 2,3,7,8-tetrachlorodibenzo-p-dioxin in MCF-7 cells with those from heterologous expression of the cDNA. Arch Biochem Biophys. 1992; 293:342-348. [PubMed: 1536570]

367. Spink DC, Hayes CL, Young NR, Christou M, Sutter TR, Jefcoate CR, Gierthy JF. The effects of 2,3,7,8-tetrachlorodibenzo-p-dioxin on estrogen metabolism in MCF-7 breast cancer cells: 
evidence for induction of a novel 17 beta-estradiol 4-hydroxylase. J Steroid Biochem Mol Biol. 1994; 51:251-258. [PubMed: 7826886]

368. Spink DC, Lincoln DW 2nd, Dickerman HW, Gierthy JF. 2,3,7,8-Tetrachlorodibenzo-p-dioxin causes an extensive alteration of 17 beta-estradiol metabolism in MCF-7 breast tumor cells. Proc Natl Acad Sci U S A. 1990; 87:6917-6921. [PubMed: 2395886]

369. Srinivasan SR, Bao W, Wattigney WA, Berenson GS. Adolescent overweight is associated with adult overweight and related multiple cardiovascular risk factors: the Bogalusa Heart Study. Metabolism. 1996; 45:235-240. [PubMed: 8596496]

370. Stahlhut RW, van Wijngaarden E, Dye TD, Cook S, Swan SH. Concentrations of urinary phthalate metabolites are associated with increased waist circumference and insulin resistance in adult U.S. males. Environ Health Perspect. 2007; 115:876-882. [PubMed: 17589594]

371. Steenland K, Piacitelli L, Deddens J, Fingerhut M, Chang LI. Cancer, heart disease, and diabetes in workers exposed to 2,3,7,8-tetrachlorodibenzo-p-dioxin. J Natl Cancer Inst. 1999; 91:779-786. [PubMed: 10328108]

372. Stellman SD, Djordjevic MV, Muscat JE, Gong L, Bernstein D, Citron ML, White A, Kemeny M, Busch E, Nafziger AN. Relative abundance of organochlorine pesticides and polychlorinated biphenyls in adipose tissue and serum of women in Long Island, New York. Cancer Epidemiol Biomarkers Prev. 1998; 7:489-496. [PubMed: 9641493]

373. Strakovsky RS, Lezmi S, Shkoda I, Flaws JA, Helferich WG, Pan YX. In utero growth restriction and catch-up adipogenesis after developmental di (2-ethylhexyl) phthalate exposure cause glucose intolerance in adult male rats following a high-fat dietary challenge. J Nutr Biochem. 2015; 26:1208-1220. [PubMed: 26188368]

374. Strakovsky RS, Wang H, Engeseth NJ, Flaws JA, Helferich WG, Pan YX, Lezmi S. Developmental bisphenol A (BPA) exposure leads to sex-specific modification of hepatic gene expression and epigenome at birth that may exacerbate high-fat diet-induced hepatic steatosis. Toxicol Appl Pharmacol. 2015; 284:101-112. [PubMed: 25748669]

375. Sugiura K, Aoki M, Kaneko S, Daisaku I, Komatsu Y, Shibuya H, Suzuki H, Goto M. Fate of 2,4,6-trichlorophenol, pentachlorophenol, p-chlorobiphenyl, and hexachlorobenzene in an outdoor experimental pond: Comparison between observations and predictions based on laboratory data. Archives of Environmental Contamination and Toxicology. 1984; 13:745-758.

376. Sun Q, Cornelis MC, Townsend MK, Tobias DK, Eliassen AH, Franke AA, Hauser R, Hu FB. Association of urinary concentrations of bisphenol A and phthalate metabolites with risk of type 2 diabetes: a prospective investigation in the Nurses' Health Study (NHS) and NHSII cohorts. Environ Health Perspect. 2014; 122:616-623. [PubMed: 24633239]

377. Sun Q, Yue P, Deiuliis JA, Lumeng CN, Kampfrath T, Mikolaj MB, Cai Y, Ostrowski MC, Lu B, Parthasarathy S, Brook RD, Moffatt-Bruce SD, Chen LC, Rajagopalan S. Ambient air pollution exaggerates adipose inflammation and insulin resistance in a mouse model of diet-induced obesity. Circulation. 2009; 119:538-546. [PubMed: 19153269]

378. Svensson K, Hernandez-Ramirez RU, Burguete-Garcia A, Cebrian ME, Calafat AM, Needham LL, Claudio L, Lopez-Carrillo L. Phthalate exposure associated with self-reported diabetes among Mexican women. Environ Res. 2011; 111:792-796. [PubMed: 21696718]

379. Swedenborg E, Pongratz I. AhR and ARNT modulate ER signaling. Toxicology. 2010; 268:132138. [PubMed: 19778576]

380. Swedenborg E, Ruegg J, Makela S, Pongratz I. Endocrine disruptive chemicals: mechanisms of action and involvement in metabolic disorders. J Mol Endocrinol. 2009; 43:1-10. [PubMed: 19211731]

381. Sweeney MH, Calvert GM, Egeland GA, Fingerhut MA, Halperin WE, Piacitelli LA. Review and update of the results of the NIOSH medical study of workers exposed to chemicals contaminated with 2,3,7,8-tetrachlorodibenzodioxin. Teratog Carcinog Mutagen. 1997; 17:241-247. [PubMed: 9508733]

382. Tang-Peronard JL, Andersen HR, Jensen TK, Heitmann BL. Endocrine-disrupting chemicals and obesity development in humans: a review. Obes Rev. 2011; 12:622-636. [PubMed: 21457182]

383. Tang-Peronard JL, Heitmann BL, Andersen HR, Steuerwald U, Grandjean P, Weihe P, Jensen TK. Association between prenatal polychlorinated biphenyl exposure and obesity development at ages 
5 and 7 y: a prospective cohort study of 656 children from the Faroe Islands. Am J Clin Nutr. 2014; 99:5-13. [PubMed: 24153349]

384. Tang-Peronard JL, Jensen TK, Andersen HR, Ried-Larsen M, Grontved A, Andersen LB, Timmermann CA, Nielsen F, Heitmann BL. Associations between Exposure to Persistent Organic Pollutants in Childhood and Overweight up to 12 Years Later in a Low Exposed Danish Population. Obes Facts. 2015; 8:282-292. [PubMed: 26228100]

385. Taxvig C, Dreisig K, Boberg J, Nellemann C, Schelde AB, Pedersen D, Boergesen M, Mandrup S, Vinggaard AM. Differential effects of environmental chemicals and food contaminants on adipogenesis, biomarker release and PPARgamma activation. Mol Cell Endocrinol. 2012; 361:106-115. [PubMed: 22526026]

386. Taylor KW, Novak RF, Anderson HA, Birnbaum LS, Blystone C, Devito M, Jacobs D, Kohrle J, Lee DH, Rylander L, Rignell-Hydbom A, Tornero-Velez R, Turyk ME, Boyles AL, Thayer KA, Lind L. Evaluation of the association between persistent organic pollutants (POPs) and diabetes in epidemiological studies: a national toxicology program workshop review. Environ Health Perspect. 2013; 121:774-783. [PubMed: 23651634]

387. Tchernof A, Calles-Escandon J, Sites CK, Poehlman ET. Menopause, central body fatness, and insulin resistance: effects of hormone-replacement therapy. Coron Artery Dis. 1998; 9:503-511. [PubMed: 9847982]

388. Teitelbaum SL, Mervish N, Moshier EL, Vangeepuram N, Galvez MP, Calafat AM, Silva MJ, Brenner BL, Wolff MS. Associations between phthalate metabolite urinary concentrations and body size measures in New York City children. Environ Res. 2012; 112:186-193. [PubMed: 22222007]

389. Teixeira D, Pestana D, Santos C, Correia-Sá L, Marques C, Norberto S, Meireles M, Faria A, Silva R, Faria G, Sá C, Freitas P, Taveira-Gomes A, Domingues V, Delerue-Matos C, Calhau C, Monteiro R. Inflammatory and cardiometabolic risk on obesity: role of environmental xenoestrogens. J Clin Endocrinol Metab. 2015; 100:1792-1801. [PubMed: 25853792]

390. Thayer KA, Heindel JJ, Bucher JR, Gallo MA. Role of environmental chemicals in diabetes and obesity: a National Toxicology Program workshop review. Environ Health Perspect. 2012; 120:779-789. [PubMed: 22296744]

391. Tomar LR, Agarwal MP, Avasthi R, Tyagi V, Mustafa M, Banerjee BD. Serum organochlorine pesticide levels in patients with metabolic syndrome. Indian J Endocrinol Metab. 2013; 17:S342344. [PubMed: 24251209]

392. Tomlin CDS. The e-Pesticide Manual. UK: British Crop Protection Council; 2004-2005. Pendimethalin.

393. Tontonoz P, Hu E, Spiegelman BM. Stimulation of adipogenesis in fibroblasts by PPAR gamma 2, a lipid-activated transcription factor. Cell. 1994; 79:1147-1156. [PubMed: 8001151]

394. Trasande L, Attina TM, Blustein J. Association between urinary bisphenol A concentration and obesity prevalence in children and adolescents. JAMA. 2012; 308:1113-1121. [PubMed: 22990270]

395. Trasande L, Spanier AJ, Sathyanarayana S, Attina TM, Blustein J. Urinary phthalates and increased insulin resistance in adolescents. Pediatrics. 2013; 132:e646-655. [PubMed: 23958772]

396. Trayhurn P, Bing C, Wood IS. Adipose tissue and adipokines-energy regulation from the human perspective. J Nutr. 2006; 136:1935S-1939S. [PubMed: 16772463]

397. Tung EW, Boudreau A, Wade MG, Atlas E. Induction of adipocyte differentiation by polybrominated diphenyl ethers (PBDEs) in 3T3-L1 cells. PLoS One. 2014; 9:e94583. [PubMed: 24722056]

398. Turyk M, Anderson HA, Knobeloch L, Imm P, Persky VW. Prevalence of diabetes and body burdens of polychlorinated biphenyls, polybrominated diphenyl ethers, and p, $\mathrm{p}^{\prime}$ diphenyldichloroethene in Great Lakes sport fish consumers. Chemosphere. 2009; 75:674-679. [PubMed: 19157498]

399. Uemura H, Arisawa K, Hiyoshi M, Kitayama A, Takami H, Sawachika F, Dakeshita S, Nii K, Satoh H, Sumiyoshi Y, Morinaga K, Kodama K, Suzuki T, Nagai M, Suzuki T. Prevalence of metabolic syndrome associated with body burden levels of dioxin and related compounds among Japan's general population. Environ Health Perspect. 2009; 117:568-573. [PubMed: 19440495] 
400. Uemura H, Arisawa K, Hiyoshi M, Satoh H, Sumiyoshi Y, Morinaga K, Kodama K, Suzuki T, Nagai M, Suzuki T. Associations of environmental exposure to dioxins with prevalent diabetes among general inhabitants in Japan. Environ Res. 2008; 108:63-68. [PubMed: 18649880]

401. Ukropec J, Radikova Z, Huckova M, Koska J, Kocan A, Sebokova E, Drobna B, Trnovec T, Susienkova K, Labudova V, Gasperikova D, Langer P, Klimes I. High prevalence of prediabetes and diabetes in a population exposed to high levels of an organochlorine cocktail. Diabetologia. 2010; 53:899-906. [PubMed: 20182860]

402. Vafeiadi M, Georgiou V, Chalkiadaki G, Rantakokko P, Kiviranta H, Karachaliou M, Fthenou E, Venihaki M, Sarri K, Vassilaki M, Kyrtopoulos SA, Oken E, Kogevinas M, Chatzi L. Association of Prenatal Exposure to Persistent Organic Pollutants with Obesity and Cardiometabolic Traits in Early Childhood: The Rhea Mother-Child Cohort (Crete, Greece). Environ Health Perspect. 2015; 123:1015-1021. [PubMed: 25910281]

403. Vafeiadi M, Roumeliotaki T, Myridakis A, Chalkiadaki G, Fthenou E, Dermitzaki E, Karachaliou M, Sarri K, Vassilaki M, Stephanou EG, Kogevinas M, Chatzi L. Association of early life exposure to bisphenol A with obesity and cardiometabolic traits in childhood. Environ Res. 2016; 146:379-387. [PubMed: 26821262]

404. Valentino R, D’Esposito V, Passaretti F, Liotti A, Cabaro S, Longo M, Perruolo G, Oriente F, Beguinot F, Formisano P. Bisphenol-A impairs insulin action and up-regulates inflammatory pathways in human subcutaneous adipocytes and 3T3-L1 cells. PLoS One. 2013; 8:e82099. [PubMed: 24349194]

405. Valvi D, Casas M, Mendez MA, Ballesteros-Gomez A, Luque N, Rubio S, Sunyer J, Vrijheid M. Prenatal bisphenol a urine concentrations and early rapid growth and overweight risk in the offspring. Epidemiology. 2013; 24:791-799. [PubMed: 24036610]

406. Valvi D, Casas M, Romaguera D, Monfort N, Ventura R, Martinez D, Sunyer J, Vrijheid M. Prenatal Phthalate Exposure and Childhood Growth and Blood Pressure: Evidence from the Spanish INMA-Sabadell Birth Cohort Study. Environ Health Perspect. 2015; 123:1022-1029. [PubMed: 25850106]

407. Valvi D, Mendez MA, Garcia-Esteban R, Ballester F, Ibarluzea J, Goni F, Grimalt JO, Llop S, Marina LS, Vizcaino E, Sunyer J, Vrijheid M. Prenatal exposure to persistent organic pollutants and rapid weight gain and overweight in infancy. Obesity (Silver Spring). 2014; 22:488-496. [PubMed: 23963708]

408. Valvi D, Mendez MA, Martinez D, Grimalt JO, Torrent M, Sunyer J, Vrijheid M. Prenatal concentrations of polychlorinated biphenyls, DDE, and DDT and overweight in children: a prospective birth cohort study. Environ Health Perspect. 2012; 120:451-457. [PubMed: 22027556]

409. Vandenberg LN, Colborn T, Hayes TB, Heindel JJ, Jacobs DR Jr, Lee DH, Shioda T, Soto AM, vom Saal FS, Welshons WV, Zoeller RT, Myers JP. Hormones and endocrine-disrupting chemicals: low-dose effects and nonmonotonic dose responses. Endocr Rev. 2012; 33:378-455. [PubMed: 22419778]

410. Vandenberg LN, Maffini MV, Sonnenschein C, Rubin BS, Soto AM. Bisphenol-A and the great divide: a review of controversies in the field of endocrine disruption. Endocr Rev. 2009; 30:7595. [PubMed: 19074586]

411. Vasiliu O, Cameron L, Gardiner J, Deguire P, Karmaus W. Polybrominated biphenyls, polychlorinated biphenyls, body weight, and incidence of adult-onset diabetes mellitus. Epidemiology. 2006; 17:352-359. [PubMed: 16755267]

412. Veith GD, Defoe DL, Bergstedt BV. Measuring and estimating the bioconcentration factor of chemicals in fish. Journal of the Fisheries Research Board of Canada. 1979; 36:1040-1048.

413. Vena J, Boffetta P, Becher H, Benn T, Bueno-de-Mesquita HB, Coggon D, Colin D, Flesch-Janys D, Green L, Kauppinen T, Littorin M, Lynge E, Mathews JD, Neuberger M, Pearce N, Pesatori AC, Saracci R, Steenland K, Kogevinas M. Exposure to dioxin and nonneoplastic mortality in the expanded IARC international cohort study of phenoxy herbicide and chlorophenol production workers and sprayers. Environ Health Perspect. 1998; 106(Suppl 2):645-653. [PubMed: 9599712] 
414. Verhulst SL, Nelen V, Hond ED, Koppen G, Beunckens C, Vael C, Schoeters G, Desager K. Intrauterine exposure to environmental pollutants and body mass index during the first 3 years of life. Environ Health Perspect. 2009; 117:122-126. [PubMed: 19165398]

415. Vogel CF, Chang WL, Kado S, McCulloh K, Vogel H, Wu D, Haarmann-Stemmann T, Yang G, Leung PS, Matsumura F, Gershwin ME. Transgenic Overexpression of Aryl Hydrocarbon Receptor Repressor (AhRR) and AhR-Mediated Induction of CYP1A1, Cytokines, and Acute Toxicity. Environ Health Perspect. 2016; 124:1071-1083. [PubMed: 26862745]

416. Vost A, Maclean N. Hydrocarbon transport in chylomicrons and high-density lipoproteins in rat. Lipids. 1984; 19:423-435. [PubMed: 6330487]

417. Wang HX, Zhou Y, Tang CX, Wu JG, Chen Y, Jiang QW. Association between bisphenol A exposure and body mass index in Chinese school children: a cross-sectional study. Environ Health. 2012; 11:79. [PubMed: 23083070]

418. Wang L, Xue J, Kannan K. Widespread occurrence and accumulation of bisphenol A diglycidyl ether (BADGE), bisphenol F diglycidyl ether (BFDGE) and their derivatives in human blood and adipose fat. Environ Sci Technol. 2015; 49:3150-3157. [PubMed: 25679329]

419. Wang N, Shi L, Kong D, Cai D, Cao Y, Liu Y, Pang G, Yu R. Accumulation levels and characteristics of some pesticides in human adipose tissue samples from Southeast China. Chemosphere. 2011; 84:964-971. [PubMed: 21722941]

420. Wang T, Li M, Chen B, Xu M, Xu Y, Huang Y, Lu J, Chen Y, Wang W, Li X, Liu Y, Bi Y, Lai S, Ning G. Urinary bisphenol A (BPA) concentration associates with obesity and insulin resistance. J Clin Endocrinol Metab. 2012; 97:E223-227. [PubMed: 22090277]

421. Wang X, Santostefano MJ, Evans MV, Richardson VM, Diliberto JJ, Birnbaum LS. Determination of parameters responsible for pharmacokinetic behavior of TCDD in female Sprague-Dawley rats. Toxicol Appl Pharmacol. 1997; 147:151-168. [PubMed: 9356318]

422. Warner M, Aguilar Schall R, Harley KG, Bradman A, Barr D, Eskenazi B. In utero DDT and DDE exposure and obesity status of 7-year-old Mexican-American children in the CHAMACOS cohort. Environ Health Perspect. 2013; 121:631-636. [PubMed: 23512307]

423. Warner M, Wesselink A, Harley KG, Bradman A, Kogut K, Eskenazi B. Prenatal exposure to dichlorodiphenyltrichloroethane and obesity at 9 years of age in the CHAMACOS study cohort. Am J Epidemiol. 2014; 179:1312-1322. [PubMed: 24722999]

424. Weigensberg MJ, Goran MI. Type 2 diabetes in children and adolescents. Lancet. 2009; 373:1743-1744. [PubMed: 19465216]

425. Weistrand C, Norén K. Polychlorinated naphthalenes and other organochlorine contaminants in human adipose and liver tissue. J Toxicol Environ Health A. 1998; 53:293-311. [PubMed: 9490327]

426. Welshons WV, Nagel SC, vom Saal FS. Large effects from small exposures. III. Endocrine mechanisms mediating effects of bisphenol A at levels of human exposure. Endocrinology. 2006; 147:S56-69. [PubMed: 16690810]

427. Witt K, Niessen KH. Toxaphenes and chlorinated naphthalenes in adipose tissue of children. J Pediatr Gastroenterol Nutr. 2000; 30:164-169. [PubMed: 10697135]

428. Wolff MS, Teitelbaum SL, Windham G, Pinney SM, Britton JA, Chelimo C, Godbold J, Biro F, Kushi LH, Pfeiffer CM, Calafat AM. Pilot study of urinary biomarkers of phytoestrogens, phthalates, and phenols in girls. Environ Health Perspect. 2007; 115:116-121. [PubMed: 17366830]

429. Wu H, Bertrand KA, Choi AL, Hu FB, Laden F, Grandjean P, Sun Q. Persistent organic pollutants and type 2 diabetes: a prospective analysis in the nurses' health study and meta-analysis. Environ Health Perspect. 2013; 121:153-161. [PubMed: 23131992]

430. Xu CX, Wang C, Zhang ZM, Jaeger CD, Krager SL, Bottum KM, Liu J, Liao DF, Tischkau SA. Aryl hydrocarbon receptor deficiency protects mice from diet-induced adiposity and metabolic disorders through increased energy expenditure. Int J Obes (Lond). 2015; 39:1300-1309. [PubMed: 25907315]

431. Yanagisawa R, Koike E, Win-Shwe TT, Yamamoto M, Takano H. Impaired lipid and glucose homeostasis in hexabromocyclododecane-exposed mice fed a high-fat diet. Environ Health Perspect. 2014; 122:277-283. [PubMed: 24398136] 
432. Yang L, Zhou Y, Sun H, Lai H, Liu C, Yan K, Yuan J, Wu T, Chen W, Zhang X. Dose-response relationship between polycyclic aromatic hydrocarbon metabolites and risk of diabetes in the general Chinese population. Environ Pollut. 2014; 195:24-30. [PubMed: 25194268]

433. Yang M, Chen M, Wang J, Xu M, Sun J, Ding L, Lv X, Ma Q, Bi Y, Liu R, Hong J, Ning G. Bisphenol A Promotes Adiposity and Inflammation in a Nonmonotonic Dose-response Way in 5week-old Male and Female C57BL/6J Mice Fed a Low-calorie Diet. Endocrinology. 2016; 157:2333-2345. [PubMed: 27145005]

434. Yu GW, Laseter J, Mylander C. Persistent organic pollutants in serum and several different fat compartments in humans. J Environ Public Health. 2011; 2011:417980. [PubMed: 21647350]

435. Zaroogian GE, Heltshe JF, Johnson M. Estimation of bioconcentration in marine species using structure-activity models. Environmental Toxicology and Chemistry. 1985; 4:3-12.

436. Zhang Y, Lin L, Cao Y, Chen B, Zheng L, Ge RS. Phthalate levels and low birth weight: a nested case-control study of Chinese newborns. J Pediatr. 2009; 155:500-504. [PubMed: 19555962]

437. Zober A, Ott MG, Messerer P. Morbidity follow up study of BASF employees exposed to 2,3,7, 8-tetrachlorodibenzo-p-dioxin (TCDD) after a 1953 chemical reactor incident. Occup Environ Med. 1994; 51:479-486. [PubMed: 8044248]

438. Zulalian J. Study of the absorption, excretion, metabolism, and residues in tissues of rats treated with carbon-14-labeled pendimethalin, PROWL herbicide. Journal of Agricultural and Food Chemistry. 1990; 38:1743-1754. 


\section{Table 1}

\section{List of Abbreviations}

\begin{tabular}{|c|c|}
\hline AhR & Aryl hydrocarbon receptor \\
\hline $\mathrm{AR}$ & Androgen receptor \\
\hline ARNT & Aryl hydrocarbon receptor nuclear translocator \\
\hline AT & Adipose tissue \\
\hline BADGE & Bisphenol A diglycidyl ether \\
\hline $\mathrm{BCF}$ & Bioconcentration factor \\
\hline BDE & Brominated diphenyl ether \\
\hline BFDGE & Bisphenol F diglycidyl ether \\
\hline BFRs & Brominated flame retardants \\
\hline$\beta-\mathrm{HCH}$ & $\beta$-Hexachlorocyclohexane \\
\hline BMI & Body mass index \\
\hline BP & Blood pressure \\
\hline BPA & Bisphenol A \\
\hline ClBPA & Monochloro-BPA \\
\hline $\mathrm{Cl}_{2} \mathrm{BPA}$ & Dichloro-BPA \\
\hline $\mathrm{Cl}_{3} \mathrm{BPA}$ & Trichloro-BPA \\
\hline CYP & Cytochrome P450 \\
\hline DBP & Dibutyl phthalate \\
\hline DDE & Dichlorodiphenyldichloroethylene \\
\hline DDT & Dichlorodiphenyltrichloroethane \\
\hline DEHP & Di(2-ethylhexyl) phthalate \\
\hline DRE & Dioxin response element \\
\hline ER & Estrogen receptor \\
\hline ERE & Estrogen response element \\
\hline ERK & Extracellular signal-regulated kinase \\
\hline Glut-4 & Glucose transporter type 4 \\
\hline HAHs & Halogenated aromatic hydrocarbons \\
\hline $\mathrm{HBCD}$ & Hexabromocyclododecane \\
\hline $\mathrm{HCB}$ & Hexachlorobenzene \\
\hline HDL & High density lipoprotein \\
\hline HMW & High molecular weight \\
\hline HOMA & Homeostatic model assessment \\
\hline HOMA-B & Homeostatic model assessment-beta \\
\hline HOMA-IR & Homeostatic model assessment- insulin resistance \\
\hline $\mathrm{HpCDD}$ & 1,2,3,4,6,7,8-Heptachlorodibenzo-p-dioxin \\
\hline $\mathrm{HxCDD}$ & 1,2,3,4,7,8-Hexachlorodibenzo-p-dioxin \\
\hline $\mathrm{K}_{\mathrm{ow}}$ & Octanol-water partition coefficient \\
\hline
\end{tabular}

Compr Physiol. Author manuscript; available in PMC 2018 September 12. 


\begin{tabular}{|c|c|}
\hline LDL & Low density lipoprotein \\
\hline LMW & Low molecular weight \\
\hline MEK & Mitogen-activated protein kinase kinase \\
\hline MBP & Mono-butyl phthalate \\
\hline MBuP & Mono-sec-butyl phthalate \\
\hline $\mathrm{MBzP}$ & Monobenzyl phthalate \\
\hline MCP-1 & Monocyte Chemoattractant Protein-1 \\
\hline MEHHP & Mono(2-ethyl-5-hydroxyhexyl) phthalate \\
\hline MEHP & Mono-(2-ethylhexyl) phthalate \\
\hline MEOHP & Mono(2-ethyl-5-oxohexyl) phthalate \\
\hline MEP & Mono-ethyl phthalate \\
\hline MetS & Metabolic syndrome \\
\hline MiBP & Mono-isobutyl phthalate \\
\hline $\mathrm{MnBP}$ & Mono-n-butyl phthalate \\
\hline NDL & Non-dioxin-like \\
\hline NHANES & National Health and Nutrition Examination Survey \\
\hline $\mathrm{OC}$ & Organochlorine \\
\hline OCDD & Octachlorodibenzodioxin \\
\hline PAHs & Polycyclic aromatic hydrocarbons \\
\hline PBBs & Polybrominated biphenyls \\
\hline PBDEs & Polybrominated diphenyl ethers \\
\hline PCBs & Polychlorinated biphenyls \\
\hline PCDDs & Polychlorinated dibenzo-p-dioxins \\
\hline PCDFs & Polychlorinated dibenzofurans \\
\hline PCP & Pentachlorophenol \\
\hline $\mathrm{PeCB}$ & Pentachlorobenzene \\
\hline PhIP & 2-amino-1-methyl-6-phenylimidazo[4-5-b]pyridine \\
\hline POPs & Persistent organic pollutants \\
\hline $\operatorname{PPAR} \gamma$ & Peroxisome proliferator-activated receptor gamma \\
\hline RXR & Retinoid $\mathrm{X}$ receptor \\
\hline scAT & Subcutaneous adipose tissue \\
\hline T1D & Type 1 diabetes \\
\hline $\mathrm{T} 2 \mathrm{D}$ & Type 2 diabetes \\
\hline TBBPA & Tetrabromobisphenol A \\
\hline TBDD & Tetrabrominated dinenzo-p-dioxin \\
\hline TBT & Tributyltin chloride \\
\hline TCBPA & Tetrachlorobisphenol A \\
\hline TCDD & 2,3,7,8-tetrachlorodibenzo-p-dioxin \\
\hline TNF-a & Tumor necrosis factor alpha \\
\hline TPTO & Bis(triphenyltin) oxide \\
\hline
\end{tabular}




\begin{tabular}{|l|l|} 
TR & Thyroid receptor \\
\hline vAT & Visceral adipose tissue \\
\hline VLDL & Very low density lipoprotein \\
\hline WC & Waist circumference \\
\hline XRE & Xenobiotic response element \\
\hline
\end{tabular}




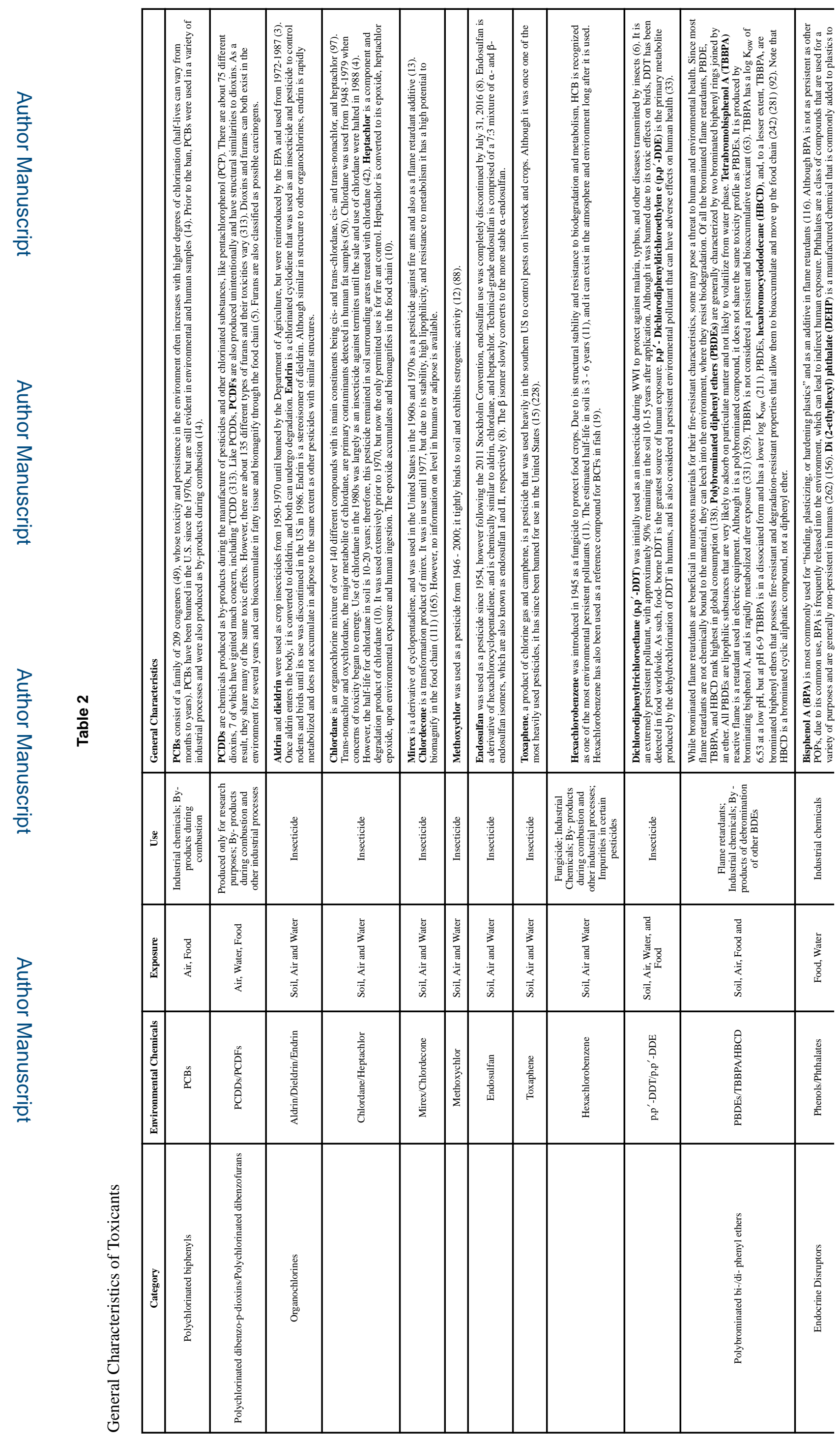




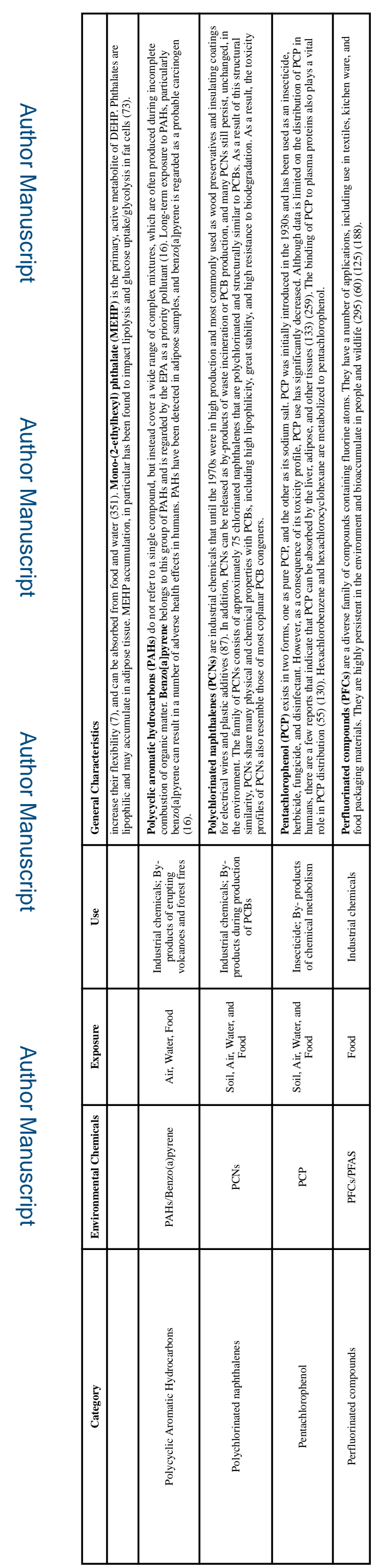


Table 3

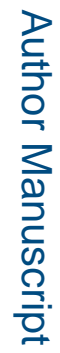

Summary of Toxicant Structures and Partition Coefficients

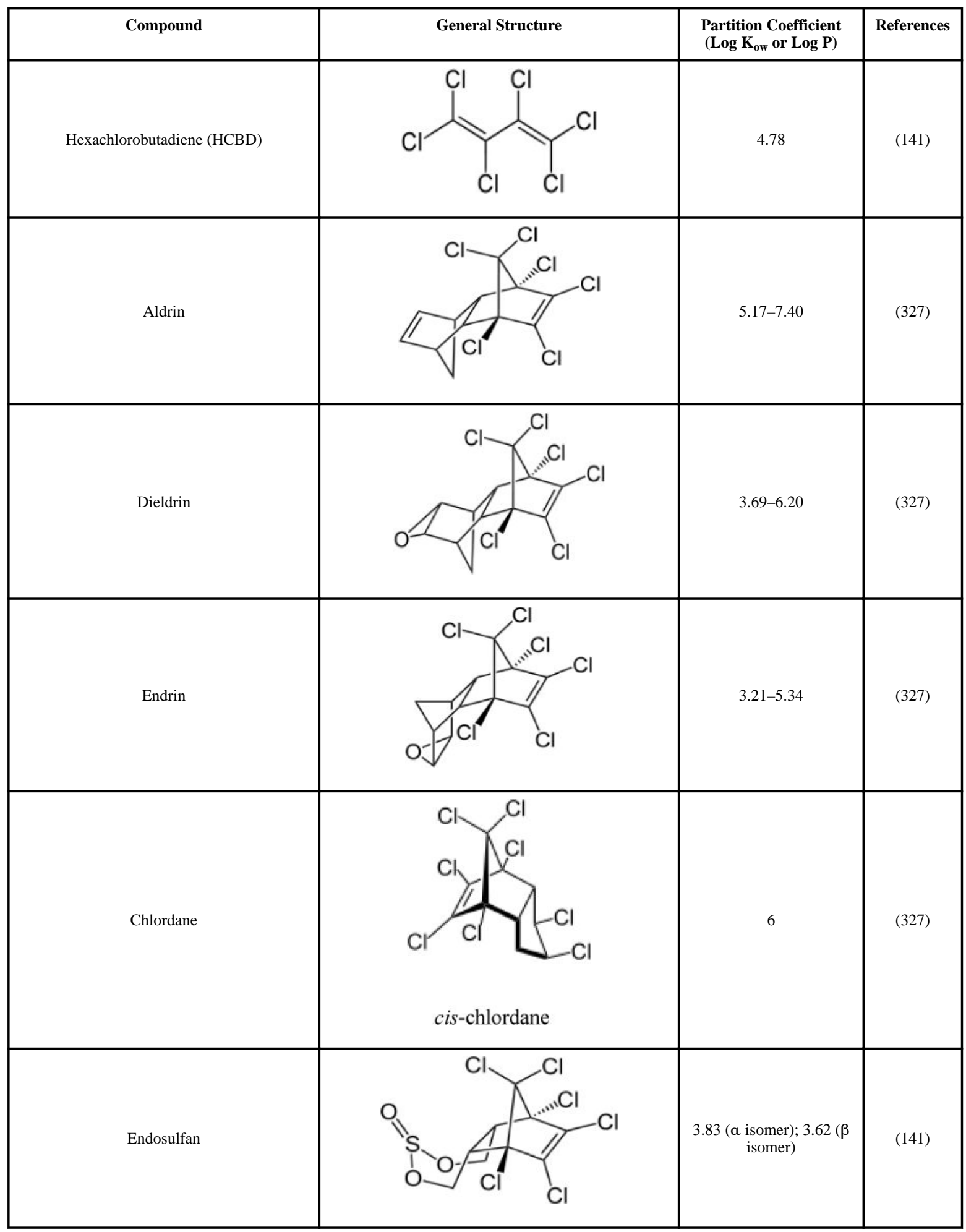

Compr Physiol. Author manuscript; available in PMC 2018 September 12. 


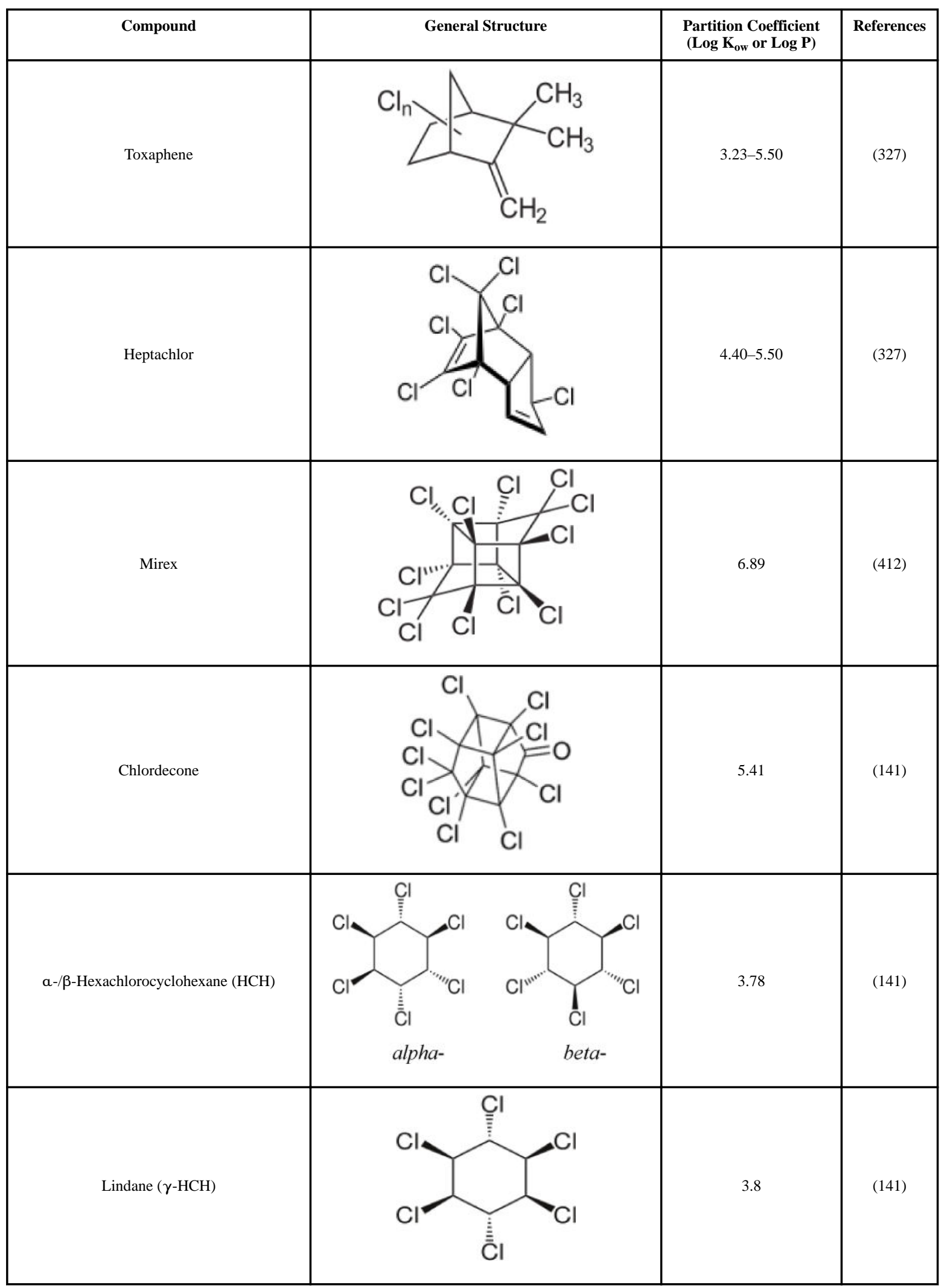

Compr Physiol. Author manuscript; available in PMC 2018 September 12. 


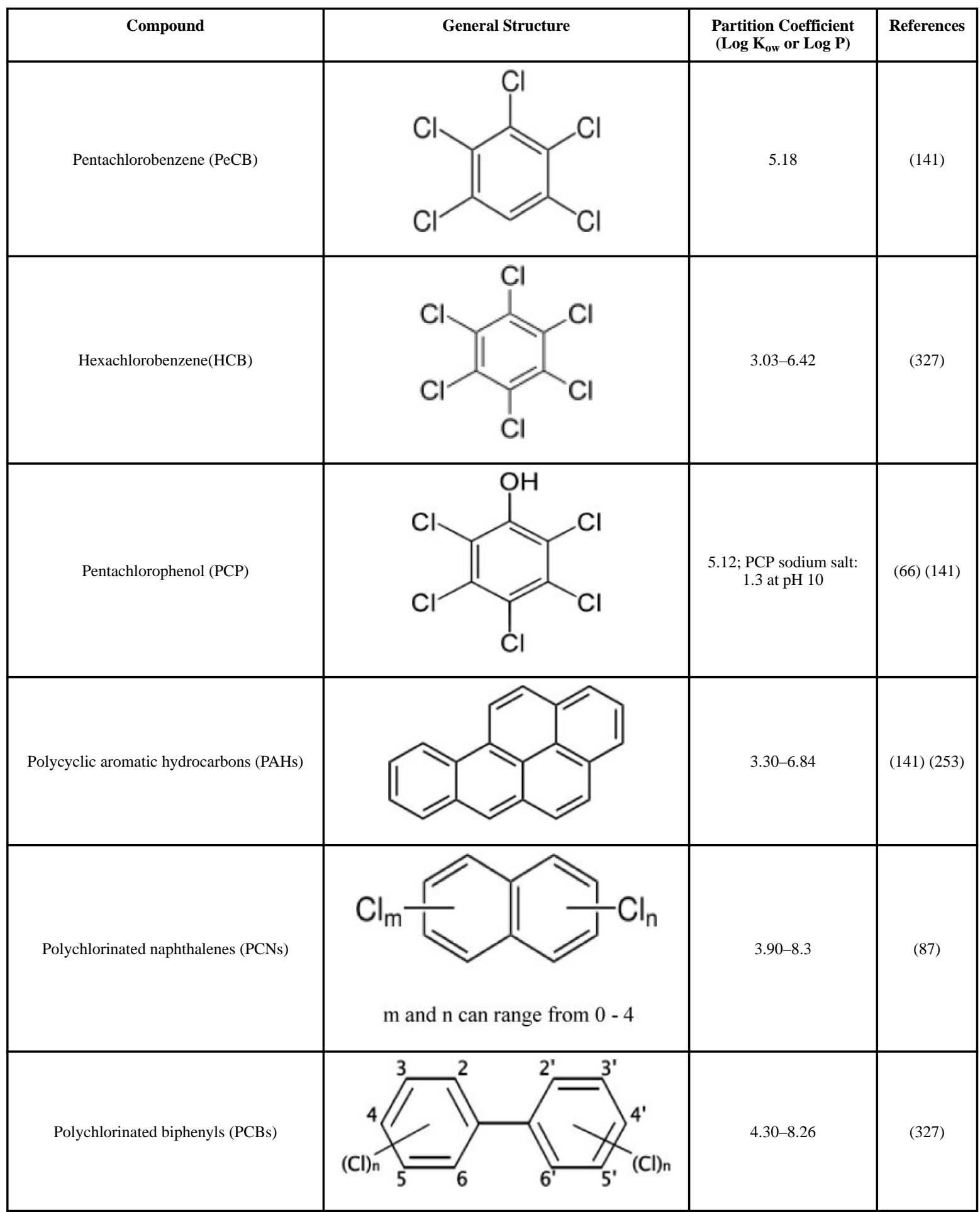




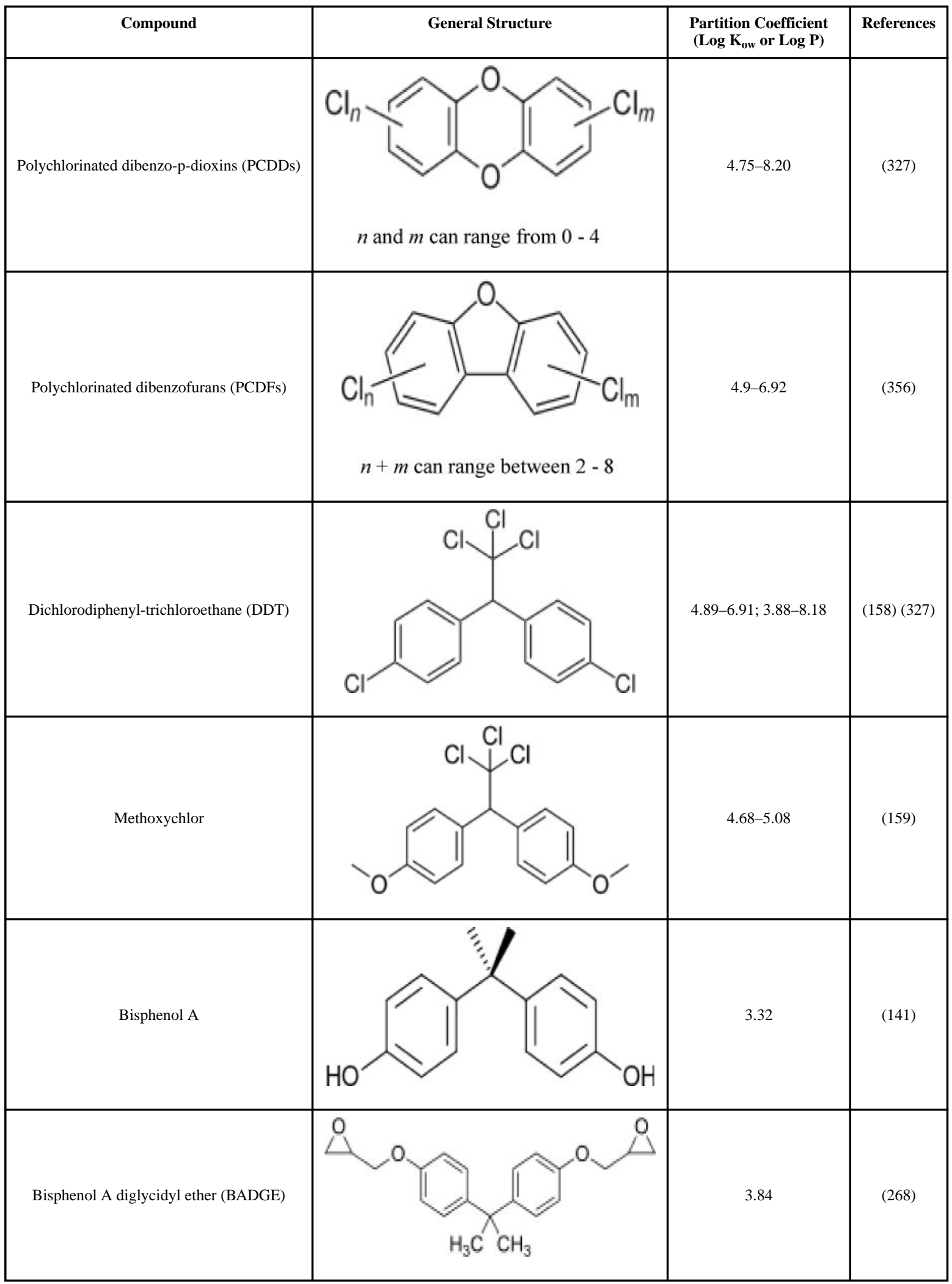

Compr Physiol. Author manuscript; available in PMC 2018 September 12. 


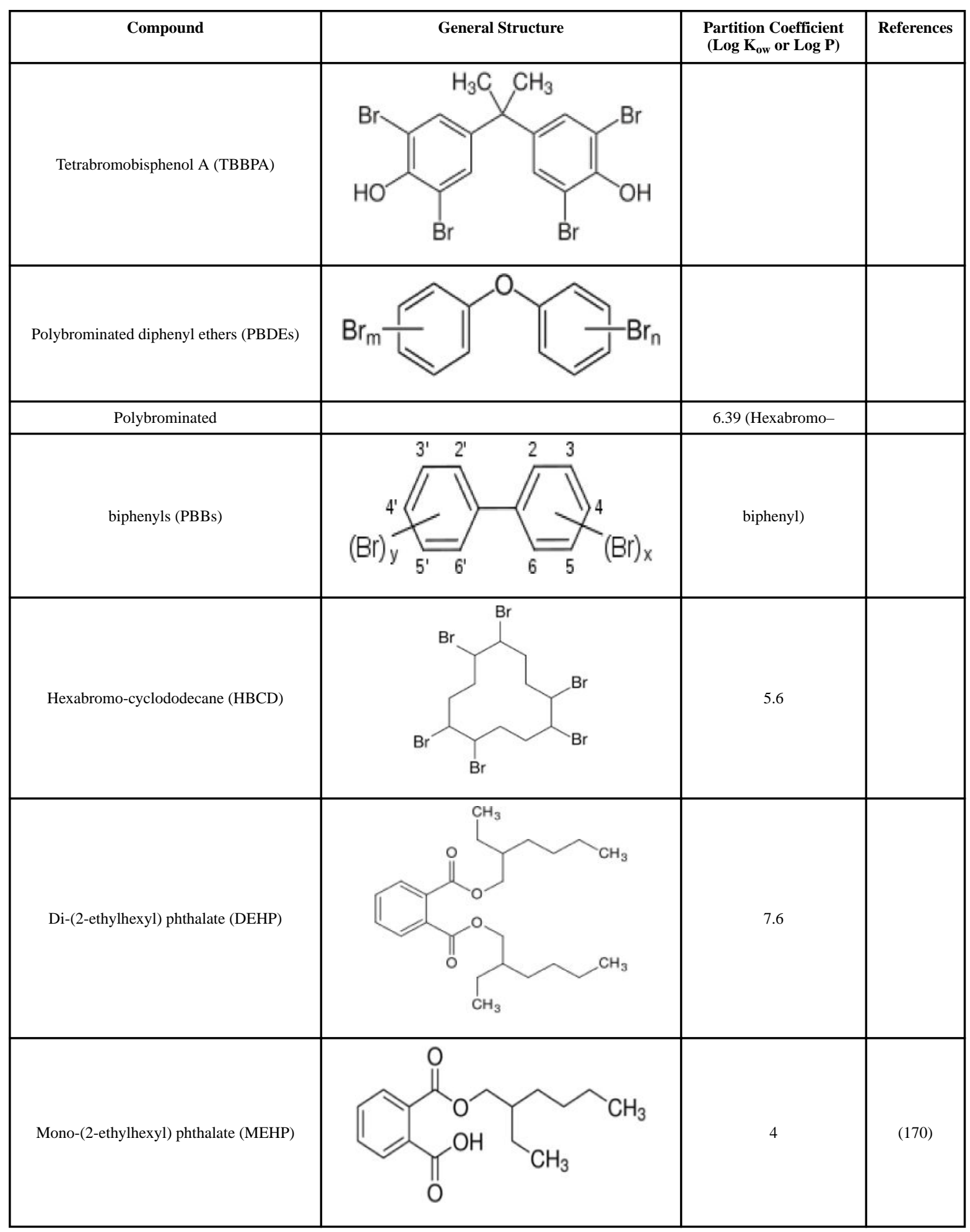




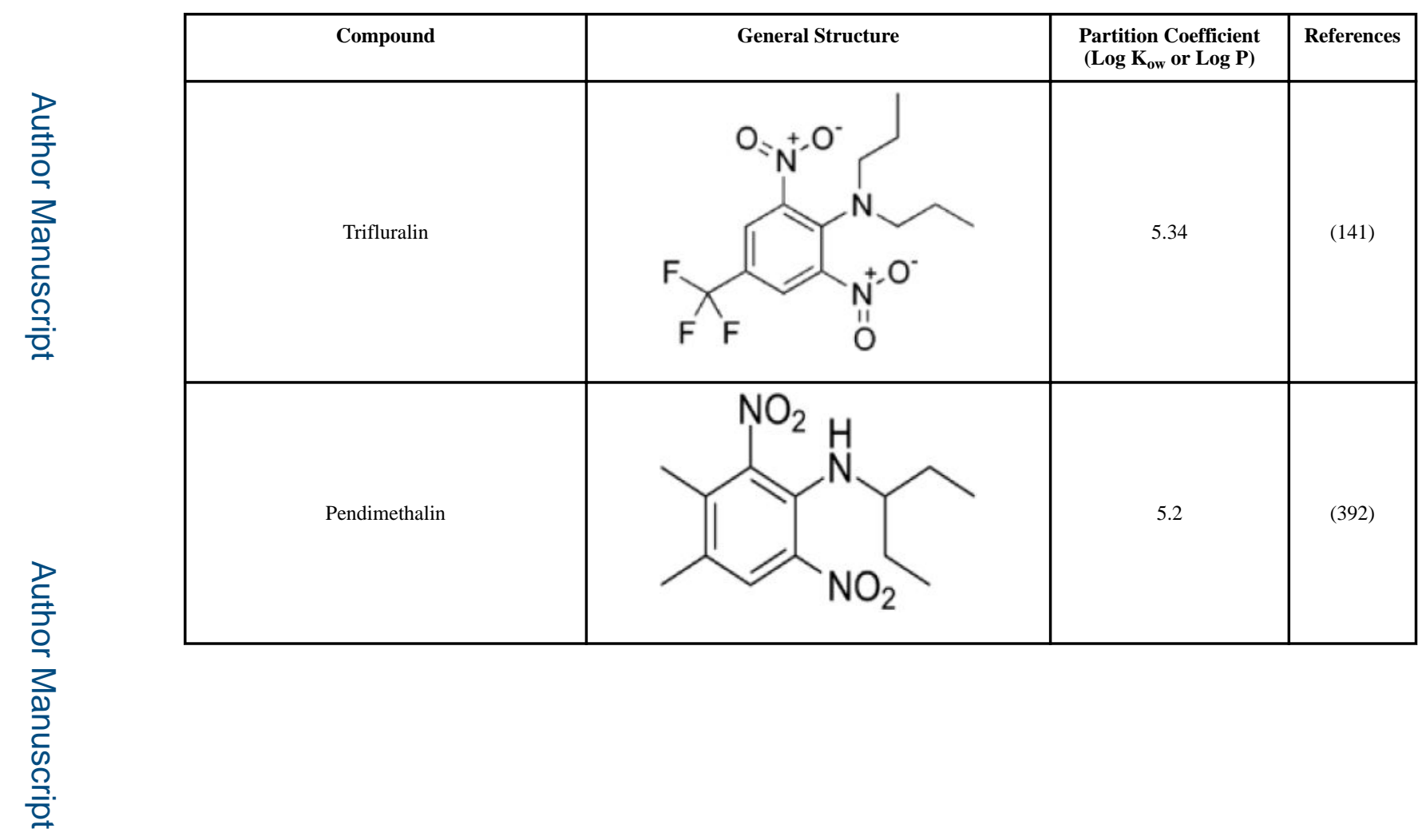

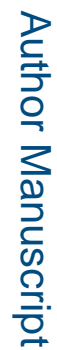

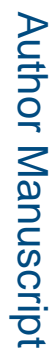




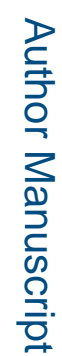

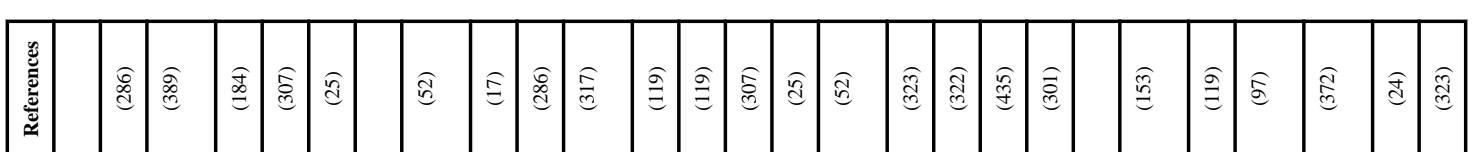

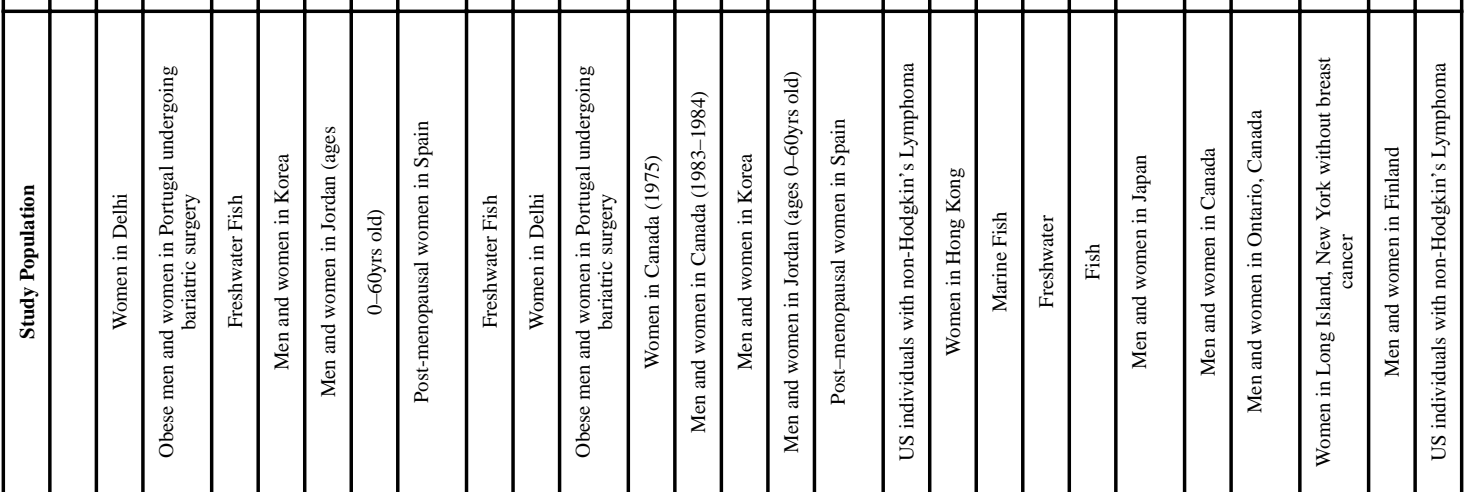

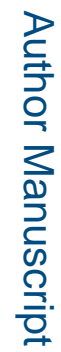

:

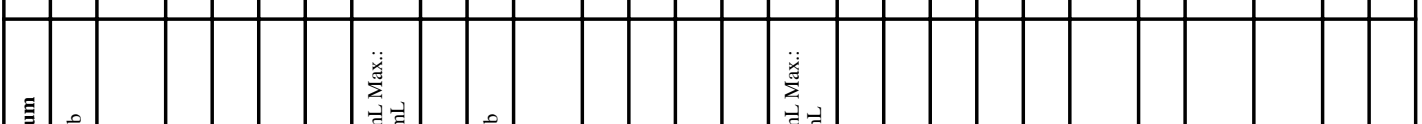

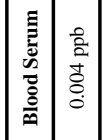

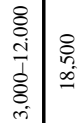

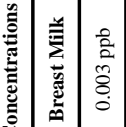

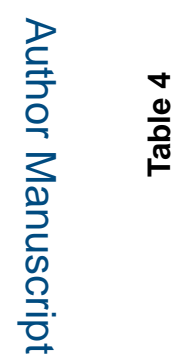

8

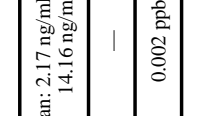

竞

?

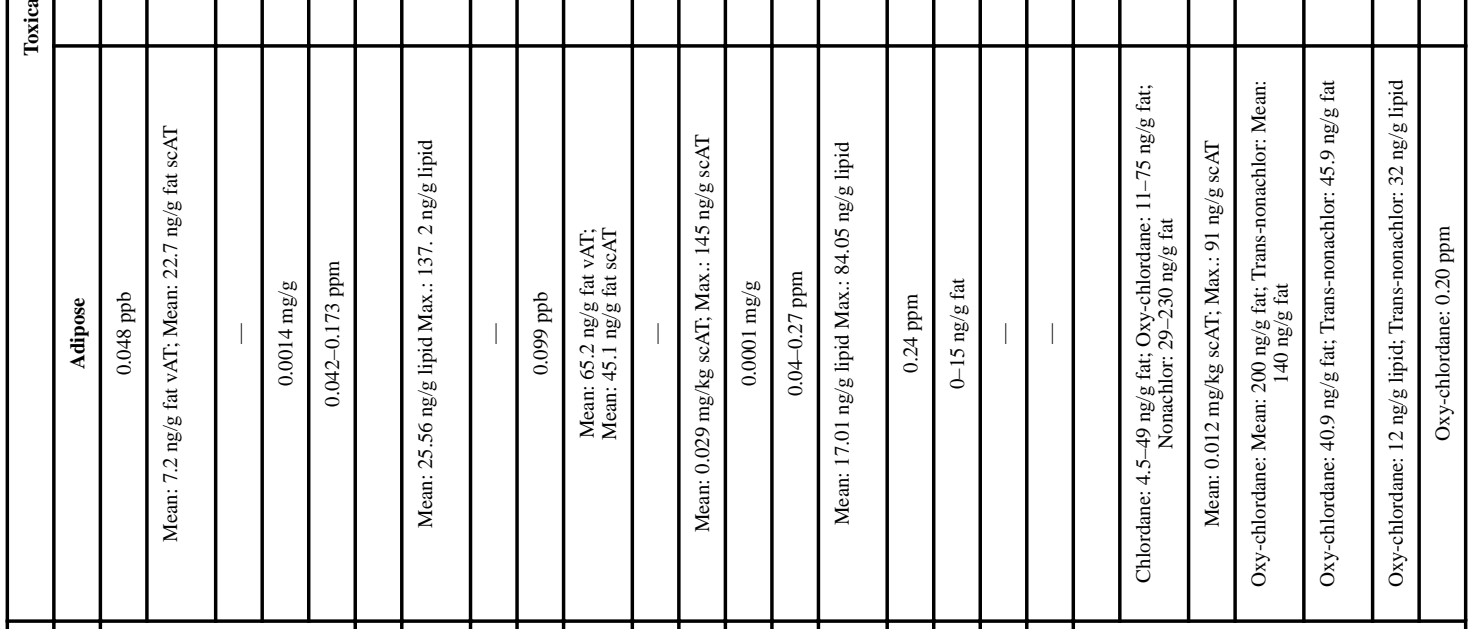

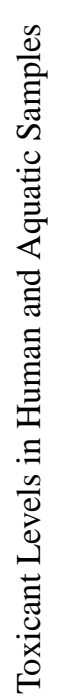

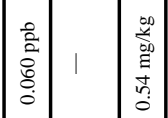

言

竞 


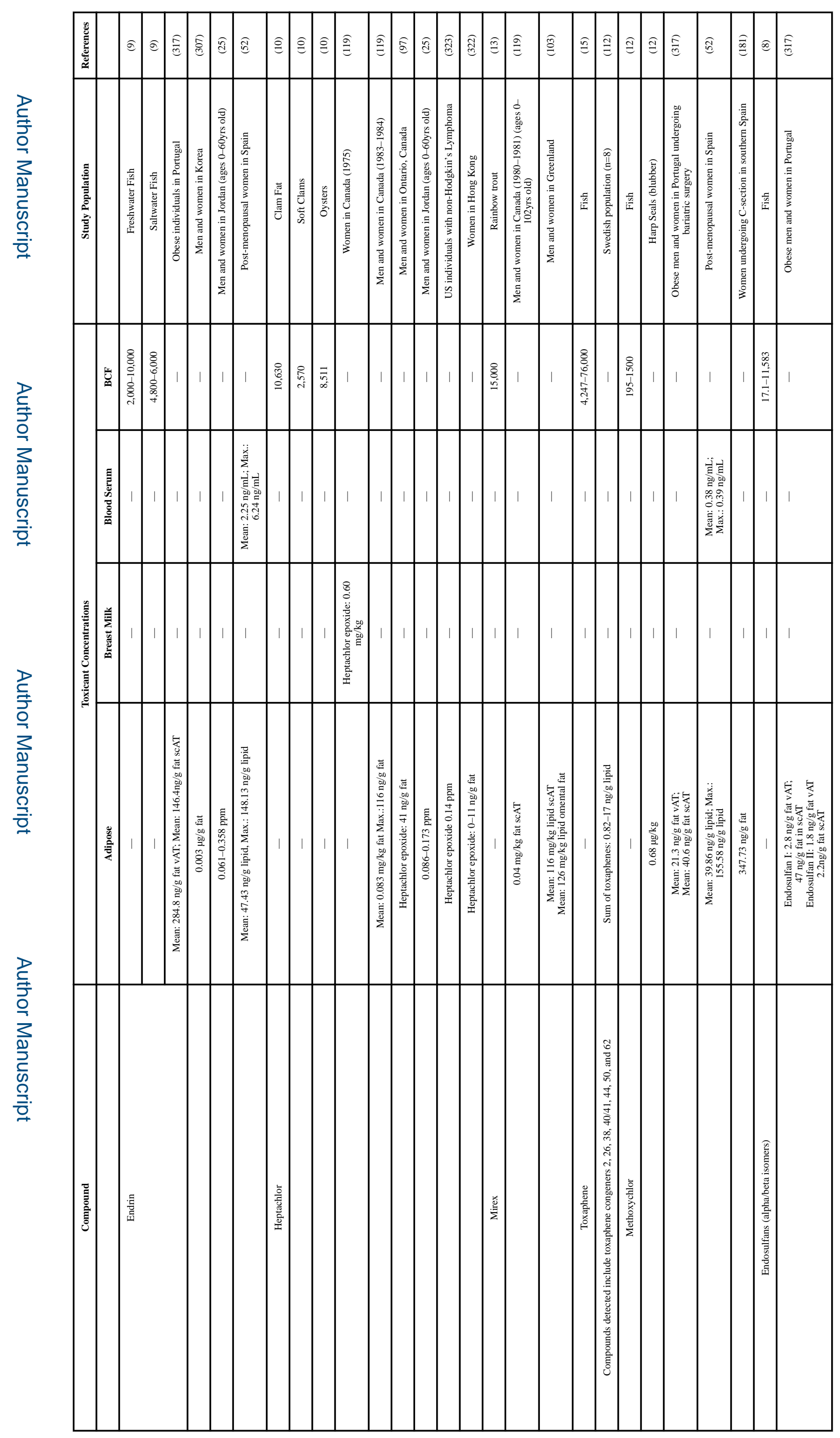




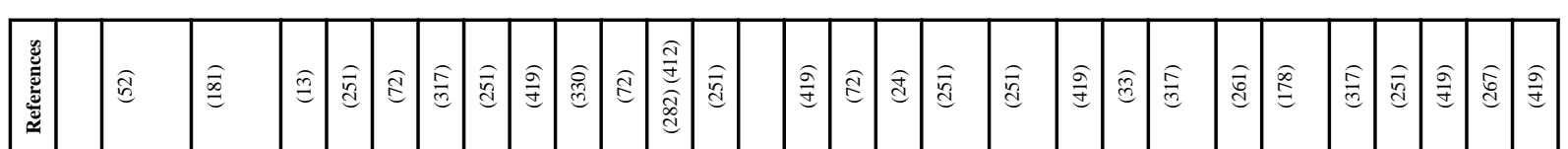

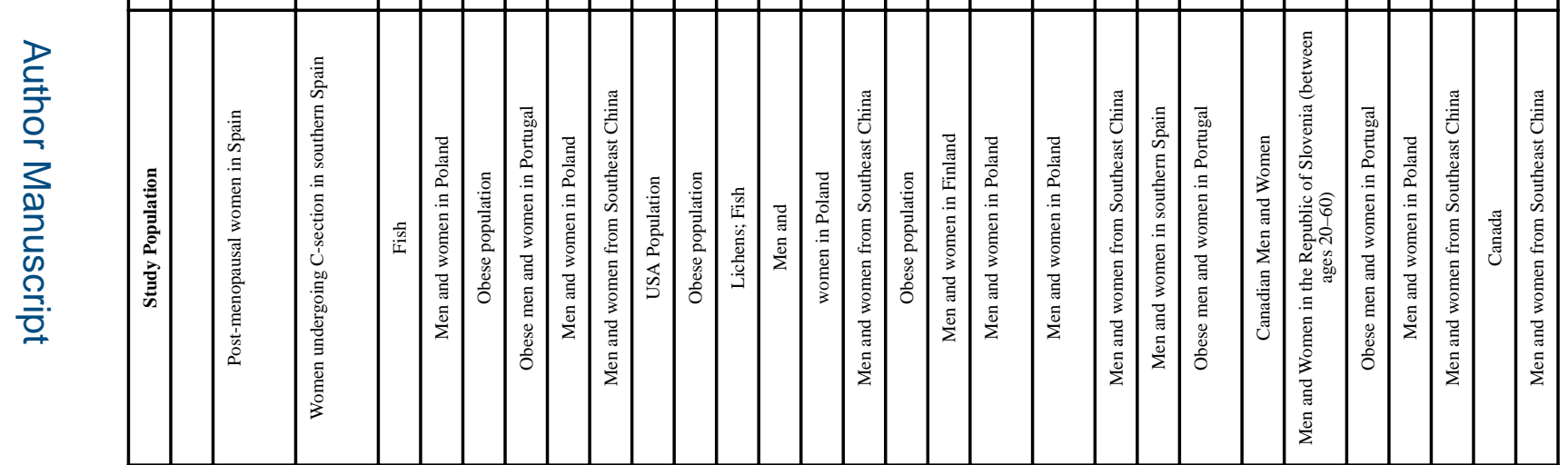

?

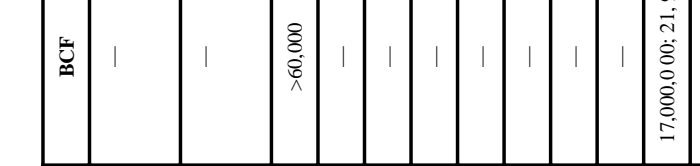

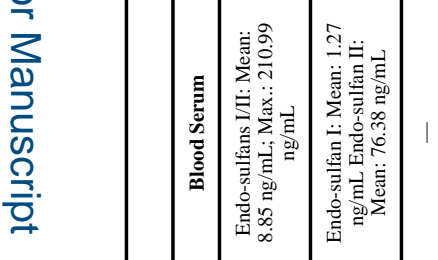

을
$\frac{\text { 을 }}{3}$

.

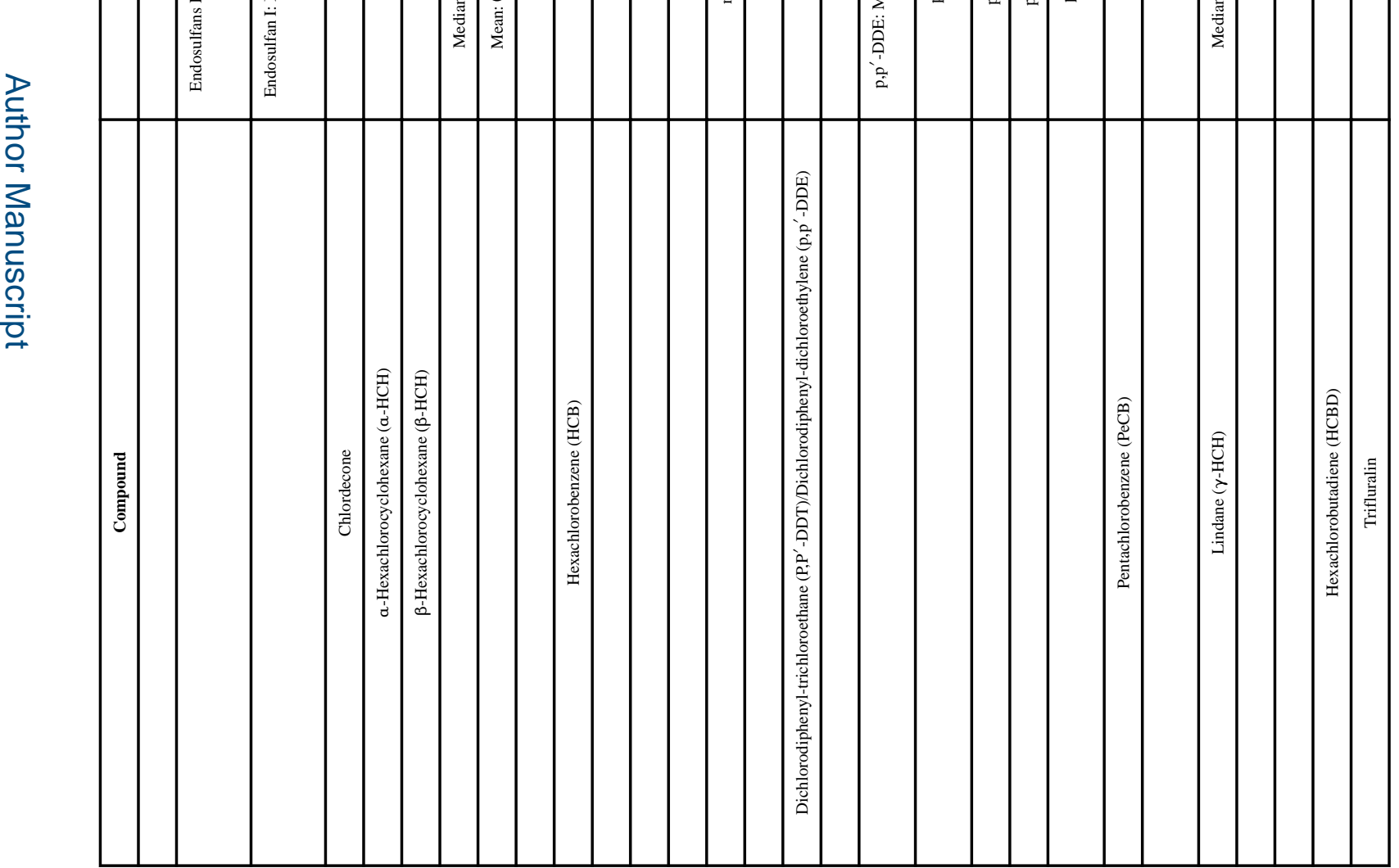




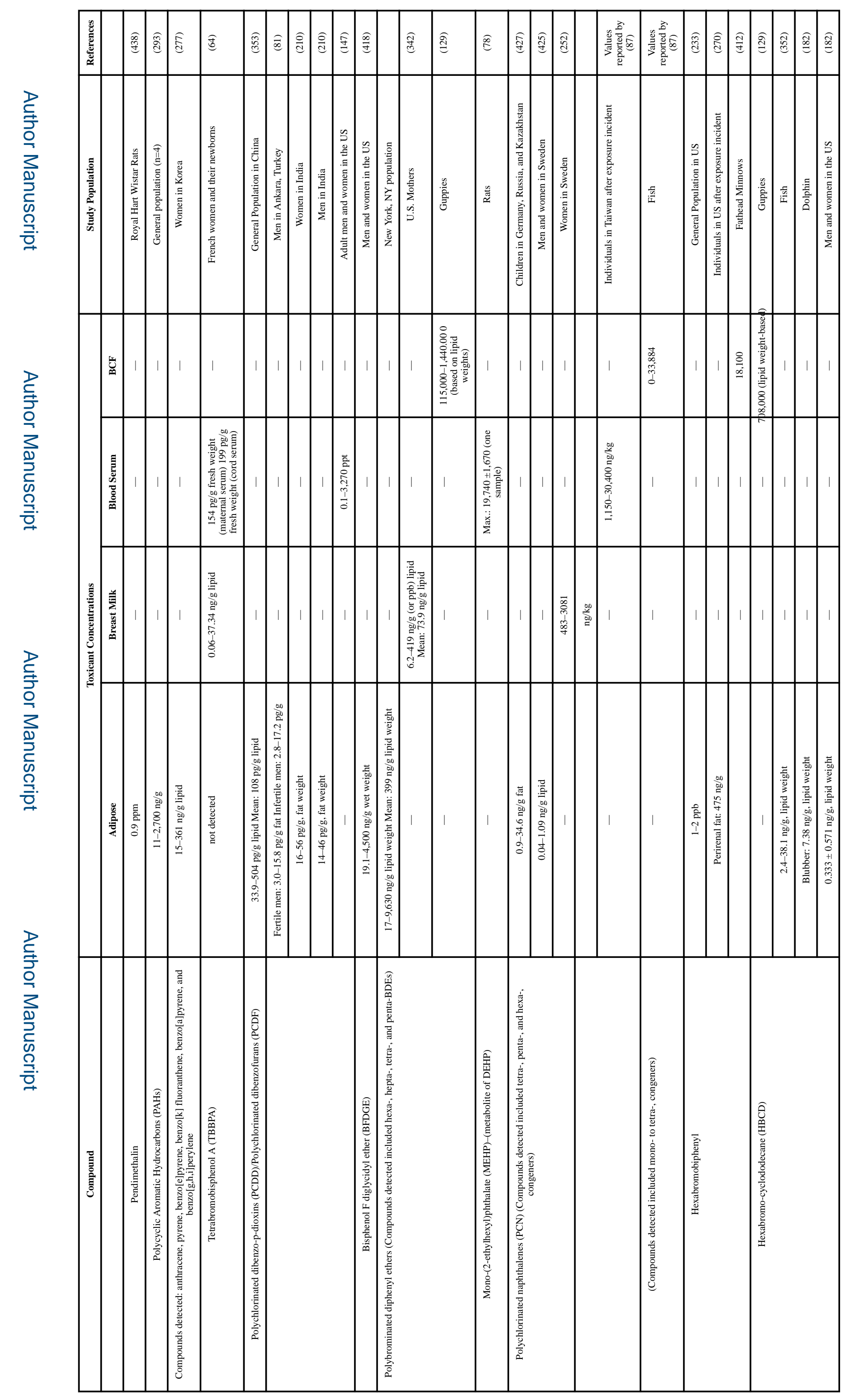




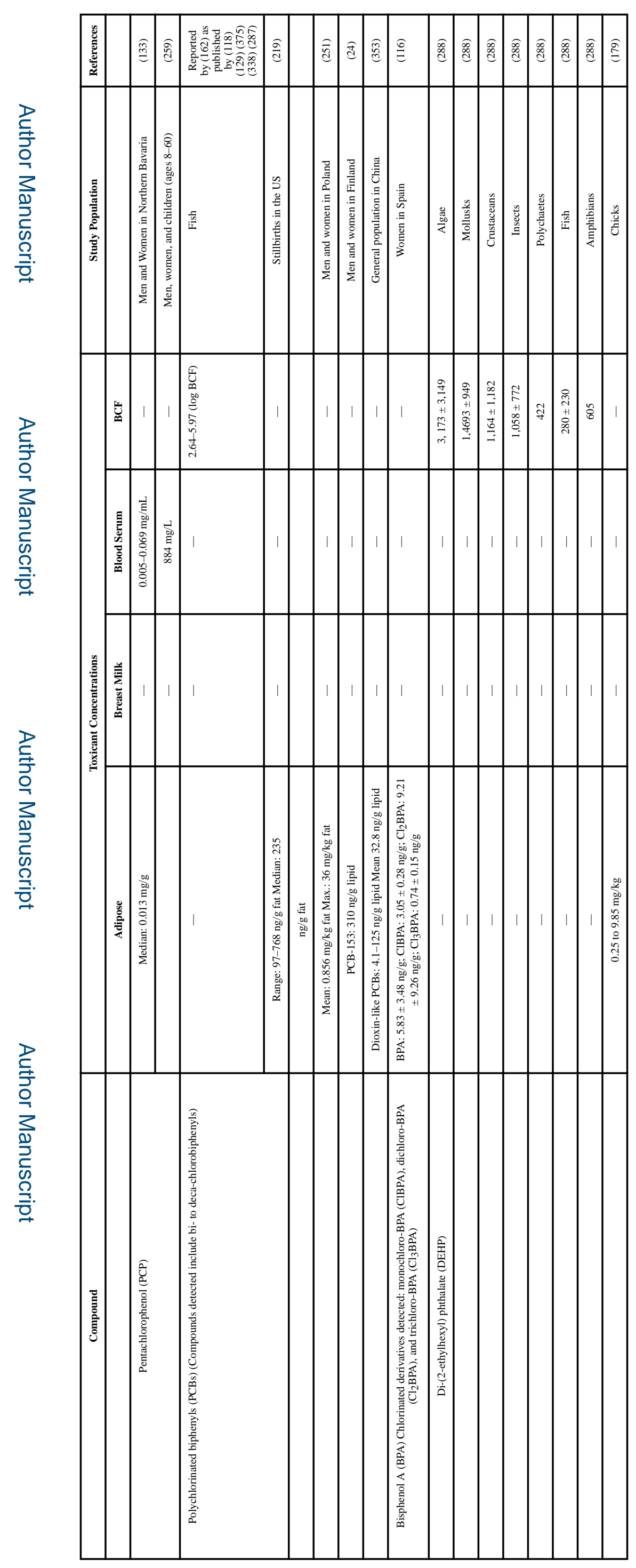




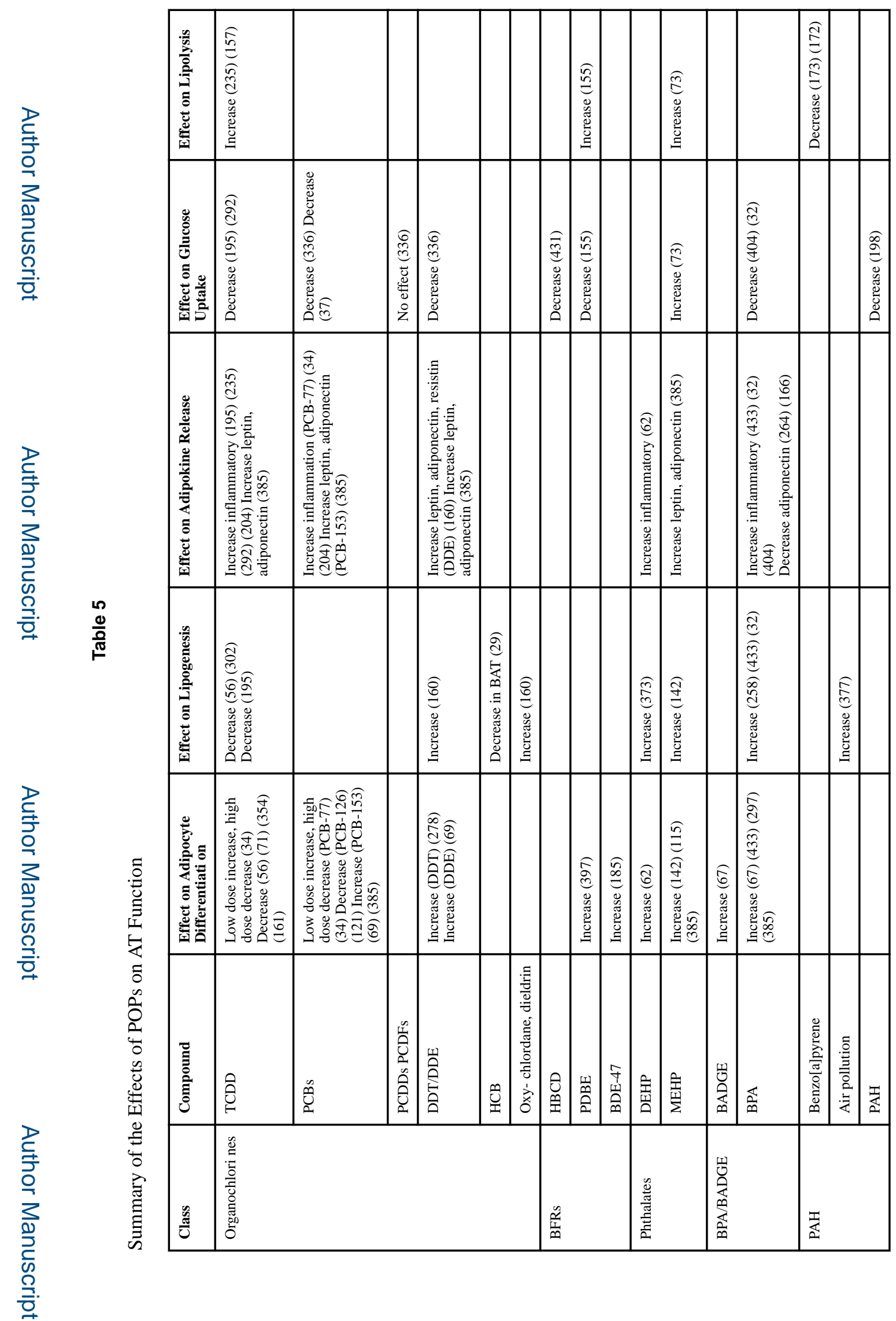

Compr Physiol. Author manuscript; available in PMC 2018 September 12. 


\section{Table 6}

\section{POP Mechanisms of Action in AT}

\begin{tabular}{|c|c|c|c|}
\hline Pathway & Normal function in adipose tissue & Purported disruptors & Impacts of disruption \\
\hline $\operatorname{PPAR} \gamma$ & $\begin{array}{l}\text { Increase adipogenesis, increase lipogenesis, } \\
\text { increase glucose uptake }\end{array}$ & $\begin{array}{l}\text { Phthalates } \\
\text { Organotins } \\
\text { BFRs? }\end{array}$ & Promote adipogenesis \\
\hline AhR & Xenosensor, regulation of lipogenesis & $\begin{array}{l}\text { Dioxins } \\
\text { PCBs } \\
\text { PAHs } \\
\text { BFRs? }\end{array}$ & $\begin{array}{l}\text { Wasting syndrome } \\
\text { Increased body weight, increased fat mass, } \\
\text { increased inflammatory response, impaired } \\
\text { glucose tolerance }\end{array}$ \\
\hline \multirow[t]{2}{*}{ ER } & \multirow[t]{2}{*}{$\begin{array}{l}\text { Inhibit lipogenesis, reduce body weight/fat mass, } \\
\text { maintain glucose homeostasis }\end{array}$} & $\mathrm{BPA}$ & $\begin{array}{l}\text { Prenatal exposure linked to increased body } \\
\text { weight and adiposity in adults }\end{array}$ \\
\hline & & AhR interaction & $\begin{array}{l}\text { Inhibition of normal estrogen function to reduce } \\
\text { body weight and adiposity }\end{array}$ \\
\hline AR & Promote glucose uptake & DDE, PCBs & Insulin resistance \\
\hline TR & Regulation of lipid mobilization and storage & BFRs AhR interaction & Unknown \\
\hline
\end{tabular}


Table 7

Prenatal POP Exposure and Associations with Obesity

\begin{tabular}{|c|c|c|c|c|}
\hline Class & Compound(s) Studied & Population & Finding & Reference \\
\hline \multirow[t]{14}{*}{ Organochlorines } & PCBs, DDE & $\begin{array}{l}\text { Mothers of Michigan fisheaters } \\
\text { cohort and their daughters }\end{array}$ & $\begin{array}{l}\text { Prenatal exposure to DDE associated } \\
\text { with increased offspring BMI. } \\
\text { Prenatal PCB had no effect. }\end{array}$ & (189) \\
\hline & PCBs, DDE, HCB & $\begin{array}{l}\text { Rhea study of pregnant women and } \\
\text { their children in Greece. }\end{array}$ & $\begin{array}{l}\text { Prenatal exposure to HCB associated } \\
\text { with BMI, obesity, abdominal } \\
\text { obesity, greater skinfold thickness, } \\
\text { and systolic BP. Prenatal DDE } \\
\text { associated with BMI, abdominal } \\
\text { obesity, and diastolic BP. PCBs not } \\
\text { associated with offspring obesity. }\end{array}$ & $(402)$ \\
\hline & $\mathrm{PCB}, \mathrm{DDE}$ & $\begin{array}{l}\text { Mother-child pairs from ENRIECO } \\
\text { cohort }\end{array}$ & $\begin{array}{l}\text { Postnatal NDL PCB-153 associated } \\
\text { with a decrease in weight-for-age z- } \\
\text { score. Prenatal DDE associated with } \\
\text { increased weight-for- age z-score. }\end{array}$ & $(174)$ \\
\hline & $\begin{array}{l}\text { Dioxins, PCBs, lead, } \\
\text { HCB, DDE, HCH }\end{array}$ & $\begin{array}{l}\text { Russian Children's Study: young } \\
\text { boys. Background exposure. }\end{array}$ & $\begin{array}{l}\text { Early exposure. Serum HCB, } \beta \text { - } \\
\text { HCH, DDE negatively associated } \\
\text { with } 4 \text { year follow-up BMI in boys. }\end{array}$ & (58) \\
\hline & $\mathrm{PBB}$ and $\mathrm{PCB}$ & $\begin{array}{l}\text { Daughters of women in the } \\
\text { Michigan PBB cohort. }\end{array}$ & $\begin{array}{l}\text { Prenatal PCB exposure negatively } \\
\text { associated with weight for height } \\
\text { females. }\end{array}$ & (47) \\
\hline & PCBs, PBB, DDT & $\begin{array}{l}\text { Women and children in Michigan } \\
\text { at risk for PCB exposure }\end{array}$ & $\begin{array}{l}\text { Prenatal PCB associated with lower } \\
\text { weight at } 4 \text { years. }\end{array}$ & $(176)$ \\
\hline & PCB, DDE, DDT & $\begin{array}{l}\text { Mothers and African American } \\
\text { children of National Collaborative } \\
\text { Perinatal Project (NCPP). } \\
\text { Background exposure. }\end{array}$ & $\begin{array}{l}\text { Maternal levels of dioxin-like PCBs } \\
\text { negatively associated with girl's } \\
\text { weight. } \\
\text { Non-dioxin-like PCBs (PCB 15) not } \\
\text { associated with girl's weight. } \\
\text { Maternal levels of dioxin-like PCBs } \\
\text { marginally associated with boy's } \\
\text { weight. }\end{array}$ & $(214)$ \\
\hline & PCBs & $\begin{array}{l}\text { Pregnant women of CHDS } \\
\text { prospective cohort study. } \\
\text { Background exposure. }\end{array}$ & $\begin{array}{l}\text { Maternal PCBs associated with lower } \\
\text { birth weight in males. }\end{array}$ & $(151)$ \\
\hline & PCBs, DDE, DDT, HCB & $\begin{array}{l}\text { AMICS-INMA Spanish cohort of } \\
\text { pregnant women and children. } \\
\text { Background exposure. }\end{array}$ & $\begin{array}{l}\text { Maternal PCB and DDE associated } \\
\text { with overweight in females but not in } \\
\text { males. DDT associated with } \\
\text { overweight in males but not } \\
\text { associated in females. }\end{array}$ & $(408)$ \\
\hline & PCBs, DDE & $\begin{array}{l}\text { Mothers and newborns in Belgium. } \\
\text { Background exposure. }\end{array}$ & $\begin{array}{l}\text { Maternal DDE and PCBs associated } \\
\text { with BMI 1-3 years. }\end{array}$ & $(414)$ \\
\hline & DDE, DDT & $\begin{array}{l}\text { Mothers and male children with } \\
\text { normal birth weights in Mexico. } \\
\text { Background exposure. }\end{array}$ & $\begin{array}{l}\text { Prenatal DDE exposure no } \\
\text { association with BMI in males. }\end{array}$ & (89) \\
\hline & PCBs and DDE & $\begin{array}{l}\text { North Carolina Infant Feeding } \\
\text { Study children. Background } \\
\text { exposure. }\end{array}$ & $\begin{array}{l}\text { Maternal transplacental DDE } \\
\text { positively associated with weight in } \\
\text { boys but not girls at } 14 \text { yrs old. } \\
\text { Lactational and trasnsplacental PCBs } \\
\text { and lactational DDE not associated } \\
\text { with weight. }\end{array}$ & (127) \\
\hline & $\begin{array}{l}\text { DDE, HCB, } \beta-\mathrm{HCH} \\
\text { NDL PCB }\end{array}$ & $\begin{array}{l}\text { INMA cohort in Spain. } \\
\text { Background exposure. }\end{array}$ & $\begin{array}{l}\text { Maternal serum: Prenatal DDE } \\
\text { associated with BMI z-scores at } 14 \\
\text { months and rapid growth (stronger } \\
\text { association in boys). } \\
\text { Other OCs (HCB, } \beta \text {-HCH, and NDL } \\
\text { PCB) not associated with BMI. }\end{array}$ & $(265)$ \\
\hline & PCBs, DDE & $\begin{array}{l}\text { Mothers of Michigan fisheaters } \\
\text { cohort and their daughters. }\end{array}$ & $\begin{array}{l}\text { Prenatal DDE associated with BMI } \\
\text { and BW in adult female offspring. }\end{array}$ & (189) \\
\hline
\end{tabular}




\begin{tabular}{|c|c|c|c|c|}
\hline Class & Compound(s) Studied & Population & Finding & Reference \\
\hline & & & $\begin{array}{l}\text { Prenatal PCBs not associated with } \\
\text { BMI in adult female offspring. }\end{array}$ & \\
\hline & DDE, DDT & $\begin{array}{l}\text { CPP study mothers and male } \\
\text { offspring. Background exposure. }\end{array}$ & $\begin{array}{l}\text { Prenatal DDE and DDT from } \\
\text { breastmilk not associated with BMI } \\
\text { in boys. }\end{array}$ & (126) \\
\hline & DDT, DDE & $\begin{array}{l}\text { CHAMACOS cohort of pregnant } \\
\text { women and children in California. } \\
\text { Background exposure. }\end{array}$ & $\begin{array}{l}\text { Maternal DDE and DDT not } \\
\text { significantly associated with BMI } \\
\text { and did not significantly increase } \\
\text { odds of overweight and obesity. }\end{array}$ & $(422)$ \\
\hline & HCB, PCBs, DDE, DDT & $\begin{array}{l}\text { Mothers and children in Asthma } \\
\text { Multicenter Infants Cohort in } \\
\text { Spain. } \\
\text { Background exposure. }\end{array}$ & $\begin{array}{l}\text { Maternal HCB associated with } \\
\text { higher BMI and increased risk of } \\
\text { being overweight and obese at age } \\
6.5 \text { yrs old. }\end{array}$ & (362) \\
\hline & $\mathrm{PCB}, \mathrm{DDE}$ & $\begin{array}{l}\text { Mother-child pairs fromFaroe } \\
\text { Islands. Background exposure. }\end{array}$ & $\begin{array}{l}\text { Prenatal PCB associated with BMI } \\
\text { and waist circumference in 7yr old } \\
\text { girls with overweight mothers. In } \\
\text { girls with normal weight mothers, } \\
\text { PCBs were associated with increased } \\
\text { WC but not associated with BMI. In } \\
\text { girls with overweight mothers, DDE } \\
\text { was associated with WC at 7yrs old. } \\
\text { No associations between PCB or } \\
\text { DDE and BMI in 5yr old girls. No } \\
\text { associations in boys. }\end{array}$ & (383) \\
\hline & PCB 153, DDE & $\begin{array}{l}\text { European birth cohorts. } \\
\text { Background exposure. }\end{array}$ & $\begin{array}{l}\text { PCB- } 153 \text { cord serum inversely } \\
\text { associated with birth weight. DDE } \\
\text { not associated with birth weight. }\end{array}$ & (131) \\
\hline & $\begin{array}{l}\text { Phthalates, BPA, PCBs, } \\
\mathrm{HCH}, \mathrm{HCB}, \text { PBDE }\end{array}$ & $\begin{array}{l}\text { Pregnant Spanish birth cohort } \\
\text { study of Environment and } \\
\text { Childhood project. Background } \\
\text { exposure. }\end{array}$ & $\begin{array}{l}\text { Exposure to HCB, } \beta \text {-HCH, PCB } 138 \\
\text { (NDL), PCB } 180(\mathrm{NDL}) \text { associated } \\
\text { with increased BMI at age 7. DDE } \\
\text { not significantly associated with } \\
\text { increased BMI. HCB, } \beta \text {-HCH, NDL } \\
\text { PCBs, and DDE associated with } \\
\text { increase in overweight at age } 7 .\end{array}$ & (21) \\
\hline & PCBs, PCDD, PCDF, & $\begin{array}{l}\text { Caucasian mother- infant pairs in } \\
\text { Netherlands. } \\
\text { Background exposure. }\end{array}$ & $\begin{array}{l}\text { NDL PCBs in cord plasma and } \\
\text { maternal plasma negatively } \\
\text { associated with birth weight and } \\
\text { growth rate } 0-3 \text { months in formula } \\
\text { fed babies but not body fat. }\end{array}$ & (308) \\
\hline & $\begin{array}{l}\text { NDL PCBs, DL PCBs, } \\
\text { DDE, HCB }\end{array}$ & $\begin{array}{l}\text { 14-15yr old Flemish adolescents. } \\
\text { Background exposure. }\end{array}$ & $\begin{array}{l}\text { Serum DL PCBs associated with } \\
\text { increased BMI and NDL PCBs and } \\
\text { HCB associated with decreased BMI } \\
\text { at puberty in males and females. } \\
\text { DDE not associated with BMI. }\end{array}$ & (104) \\
\hline & DDE, HCB, NDL PCBs & $\begin{array}{l}\text { INMA birth cohort in Spain. } \\
\text { Background exposure. }\end{array}$ & $\begin{array}{l}\text { Prenatal DDE and HCB associated } \\
\text { with rapid growth } 0-6 \text { months and } \\
\text { overweight at } 14 \text { months. PCBs not } \\
\text { associated with rapid growth or } \\
\text { overweight. }\end{array}$ & (405) \\
\hline & $\begin{array}{l}\text { DDE, phthalates, NDL } \\
\text { PCB }\end{array}$ & $\begin{array}{l}\text { Dutch mother- daughter pairs. } \\
\text { Background exposure. }\end{array}$ & $\begin{array}{l}\text { Maternal DDE associated with } \\
\text { increased BMI 6-11 months. NDL } \\
\text { PCB not associated with BMI. }\end{array}$ & (95) \\
\hline & DDE, HCB, NDL PCBs & Spanish mother-child pairs & $\begin{array}{l}\text { Maternal HCB and DDE associated } \\
\text { with rapid growth and overweight. } \\
\text { PCBs not associated with postnatal } \\
\text { growth. }\end{array}$ & (407) \\
\hline & DDE, DDT, PCBs, $\mathrm{HCH}$ & $\begin{array}{l}\text { CPP mother-child pairs in US. } \\
\text { Background exposure. }\end{array}$ & $\begin{array}{l}\text { Prenatal HCB, heptachlor, } \beta \text {-HCH, } \\
\text { DDE, total PCBs, trans-nonachlor, } \\
\text { and oxychlordane not associated with } \\
\text { obesity or BMI at age } 7 \text {. Dieldrin } \\
\text { associated with obesity but not BMI. }\end{array}$ & (90) \\
\hline & NDL PCBs, DDE, HCB & $\begin{array}{l}\text { Flemish mother-child pairs from } \\
\text { FLEHS I }\end{array}$ & $\begin{array}{l}\text { Prenatal DDE associated with WC } \\
\text { and waist/height ratio in girls. PCBs, }\end{array}$ & (101) \\
\hline
\end{tabular}




\begin{tabular}{|c|c|c|c|c|}
\hline Class & Compound(s) Studied & Population & Finding & Reference \\
\hline & & & $\begin{array}{l}\text { dioxins, HCB not associated with } \\
\text { WC. }\end{array}$ & \\
\hline & DDE, DDT & $\begin{array}{l}\text { American mother- child pairs in } \\
\text { CHAMACOS study }\end{array}$ & $\begin{array}{l}\text { In boys, prenatal DDT associated } \\
\text { with BMI, WCz-scores, and } \\
\text { overweight/obesity at 9yrs old. DDE } \\
\text { not associated. Girls not associated. }\end{array}$ & (423) \\
\hline & PCB, DDE, HCB & Danish children in EYHS study & $\begin{array}{l}\text { PCBs, DDE, HCB in } 8-22 y r \text { olds not } \\
\text { associated with obesity. }\end{array}$ & (384) \\
\hline & $\begin{array}{l}\text { DDT, DDE, HCB, } \beta- \\
\text { HCH, total PCBs }\end{array}$ & $\begin{array}{l}\text { Mother-child pairs in Spain. } \\
\text { Background exposure. }\end{array}$ & $\begin{array}{l}\text { Prenatal DDT and DDE associated } \\
\text { with decreased birth weight. HCB, } \beta \text { - } \\
\text { HCH, PCB not associated. }\end{array}$ & (248) \\
\hline & PCBs & $\begin{array}{l}\text { Mother-child pairs in NY. } \\
\text { Background exposure. }\end{array}$ & $\begin{array}{l}\text { Preconception PCBs associated with } \\
\text { reduced birth weight. }\end{array}$ & (284) \\
\hline \multirow[t]{5}{*}{$\begin{array}{l}\text { Poly-brominated } \\
\text { flame retardants } \\
\text { (BFRs) }\end{array}$} & PBDE & $\begin{array}{l}\text { Pregnant Long-Evans hooded rats } \\
\text { dosed with } 1 \text { or } 10 \mathrm{mg} / \mathrm{kg} \\
\text { bodyweight PBDE- } 99\end{array}$ & $\begin{array}{l}\text { Prenatal exposure to PBDE-99 } \\
\text { increased rat offspring birth weight. }\end{array}$ & (238) \\
\hline & PBB and PCB & $\begin{array}{l}\text { Daughters of women in the } \\
\text { Michigan PBB cohort. }\end{array}$ & $\begin{array}{l}\text { Moderate (but not high) prenatal } \\
\text { PBB exposure associated with } \\
\text { increased weight for height in } \\
\text { females. }\end{array}$ & (47) \\
\hline & $\begin{array}{l}\text { Phthalates, BPA, PCBs, } \\
\text { HCH, HCB, PBDE }\end{array}$ & $\begin{array}{l}\text { Pregnant Spanish birth cohort } \\
\text { study of Environment and } \\
\text { Childhood project. Background } \\
\text { exposure. }\end{array}$ & $\begin{array}{l}\text { PBDE not associated with child } \\
\text { weight status. }\end{array}$ & (21) \\
\hline & PBDE & $\begin{array}{l}\text { Mexican-American mother-child } \\
\text { pair of CHAMACOS study }\end{array}$ & $\begin{array}{l}\text { Maternal PBDE associated with } \\
\text { decreased BMI z-scores in girls but } \\
\text { NS in boys. } \\
\text { Child's serum BDE-153 negatively } \\
\text { associated with BMI and WC at 7yrs } \\
\text { old in both sexes. }\end{array}$ & (113) \\
\hline & PBDE & $\begin{array}{l}\text { Mexican-American mother-child } \\
\text { pairs of CHAMACOS }\end{array}$ & $\begin{array}{l}\text { Maternal PBDEs associated with } \\
\text { lower birth weight, but effect is } \\
\text { nonsignificant when maternal weight } \\
\text { gain is included. }\end{array}$ & (144) \\
\hline \multirow{8}{*}{$\begin{array}{l}\text { Polycyclic } \\
\text { Aromatic } \\
\text { Hydrocarbons } \\
\text { (PAHs) }\end{array}$} & $\mathrm{PAH}$ & $\begin{array}{l}\text { MOCEH study in Korea without } \\
\text { diabetes }\end{array}$ & $\begin{array}{l}\text { Consumption of foods high in PAH } \\
\text { (i.e. grilled or roasted meat) } \\
\text { associated with reduced birth weight. }\end{array}$ & (215) \\
\hline & $\mathrm{PAH}$ & $\begin{array}{l}\text { Birth cohort in Poland, } \\
\text { nonsmoking mothers. }\end{array}$ & $\begin{array}{l}\text { Maternal dietary and airborne PAH } \\
\text { exposure associated with reduced } \\
\text { birth weight. }\end{array}$ & (180) \\
\hline & $\mathrm{PAH}$ & $\begin{array}{l}\text { Birth cohort in Poland. } \\
\text { Background exposure. }\end{array}$ & $\begin{array}{l}\text { Newborn PAH-DNA adduct levels } \\
\text { associated with reduced birth weight. }\end{array}$ & (315) \\
\hline & $\mathrm{PAH}$ & $\begin{array}{l}\text { Birth cohort in Poland. } \\
\text { Background exposure. }\end{array}$ & $\begin{array}{l}\text { Newborn PAH-DNA adduct levels } \\
\text { associated with reduced birth weight. }\end{array}$ & (314) \\
\hline & $\mathrm{PAH}$ & $\begin{array}{l}\text { Krakow Caucasians, NYC African } \\
\text { Americans, NYC Dominicans }\end{array}$ & $\begin{array}{l}\text { Relatively low levels of prenatal PAH } \\
\text { exposure associated with reduced } \\
\text { birth weight. }\end{array}$ & (76) \\
\hline & PAH & NHANES 2003-2008 16-18yr olds & $\begin{array}{l}\text { PAH metabolites associated with } \\
\text { BMI and WC in } 6-18 y \text { rolds. High } \\
\text { exposure to both PAH and } \\
\text { environmental tobacco smoke } \\
\text { associated with increased obesity as } \\
\text { compared to low-PAH, low-ETS. }\end{array}$ & (197) \\
\hline & $\mathrm{PAH}$ & $\begin{array}{l}\text { African-Americans and Hispanic } \\
\text { children and mothers in NY }\end{array}$ & $\begin{array}{l}\text { Prenatal PAH exposure associated } \\
\text { with higher childhood BMI and risk } \\
\text { for obesity at } 5-7 \text { yrs old. }\end{array}$ & (335) \\
\hline & PAH & NHANES 2001-2006 6-19yr olds & $\begin{array}{l}\text { Early exposure: mass sum of PAH } \\
\text { associated with BMI z-score, WC, } \\
\text { and obesity. }\end{array}$ & (346) \\
\hline
\end{tabular}




\begin{tabular}{|c|c|c|c|c|}
\hline Class & Compound(s) Studied & Population & Finding & Reference \\
\hline \multirow[t]{10}{*}{ Phthalate Esters } & Phthalates, BPA & Korean girls 6-14yrs old & $\begin{array}{l}\text { Early exposure 6-14yr old female: } \\
\text { urine MEP not associated with } \\
\text { childhood obesity. Urine PA } \\
\text { associated with obesity. Serum MEP, } \\
\text { PA, and DBP associated with } \\
\text { childhood obesity. }\end{array}$ & (77) \\
\hline & Phthalates & $\begin{array}{l}\text { NHANES 1999-2002. Background } \\
\text { exposure. }\end{array}$ & $\begin{array}{l}\text { Early exposure: serum MEP } \\
\text { associated with BMI and WC in } \\
12-19 \mathrm{yr} \text { old females, but not } \\
\text { associated in 6-11yr old males or } \\
\text { females, or in 12-19yr old males. } \\
\text { MEHP associated with decreased } \\
\text { BMI in 12-19yr old females, not } \\
\text { associated in 6-11 males and } \\
\text { females, or in 12-19yr old males. } \\
\text { MBP and MEOHP were not } \\
\text { associated with BMI. }\end{array}$ & (145) \\
\hline & Phthalates, BPA & Girls in US & $\begin{array}{l}\text { MEP, MEHHP, MEHP, MECPP, } \\
\text { MBzP, MiBP, MCPP, MBP, and } \\
\text { MEOHP not associated with BMI in } \\
\text { 6-9yr old girls. }\end{array}$ & (428) \\
\hline & $\begin{array}{l}\text { Phthalates, BPA, PCBs, } \\
\mathrm{HCH}, \mathrm{HCB}, \text { PBDE }\end{array}$ & $\begin{array}{l}\text { Pregnant Spanish birth cohort } \\
\text { study of Environment and } \\
\text { Childhood project. Background } \\
\text { exposure. }\end{array}$ & $\begin{array}{l}\text { Phthalates inversely associated with } \\
\text { overweight. }\end{array}$ & (21) \\
\hline & Phthalates & $\begin{array}{l}\text { INMA Spanish birth cohort. } \\
\text { Background exposure. }\end{array}$ & $\begin{array}{l}\text { High MW phthalate metabolites } \\
\text { associated with lower weight gain } \\
\text { and BMI z-score in boys and higher } \\
\text { BMI in girls. Low MW metabolites } \\
\text { not associated with BMI or weight } \\
\text { gain. }\end{array}$ & (406) \\
\hline & Phthalates & $\begin{array}{l}\text { Hispanic and Black NY children } \\
6-8 \text { yrs old }\end{array}$ & $\begin{array}{l}\text { Early exposure: MEP and low MWP } \\
\text { associated with BMI and WC in } \\
\text { overweight children but not normal } \\
\text { weight children. }\end{array}$ & (388) \\
\hline & Phthalates & NHANES 2003-2008 & $\begin{array}{l}\text { Early exposure: Low MW } \\
\text { metabolites (Mn BP, MEP, and } \\
\text { MiBP) associated with obesity in } \\
\text { male children and adolescents. Not } \\
\text { associated for high MW and obesity }\end{array}$ & $(59)$ \\
\hline & $\begin{array}{l}\text { DDE, phthalates, NDL } \\
\text { PCB }\end{array}$ & $\begin{array}{l}\text { Dutch mother-daughter pairs. } \\
\text { Background exposure. }\end{array}$ & $\begin{array}{l}\text { Maternal exposure to low exposure } \\
\text { of MEOHP (DEHP metabolite) } \\
\text { associated with higher BMI. }\end{array}$ & (95) \\
\hline & Phthalates & Mother-child pairs in China & $\begin{array}{l}\text { Prenatal DBP associated with low } \\
\text { birth weight. }\end{array}$ & (436) \\
\hline & Phthalates & $\begin{array}{l}\text { Children 4-9yrs old in Denmark } \\
\text { without diabetes }\end{array}$ & $\begin{array}{l}\text { Urinary MEHP (percent of DEHP } \\
\text { metabolites excreted as MEHP) } \\
\text { associated with wetght. }\end{array}$ & (48) \\
\hline \multirow[t]{4}{*}{$\begin{array}{l}\text { Bisphenol A and } \\
\text { Bisphenol A } \\
\text { diglycidyl ether } \\
\text { (BADGE) }\end{array}$} & $\mathrm{BPA}$ & RHEApregnancy cohort in Greece & $\begin{array}{l}\text { BPA levels at } 4 \text { years associated with } \\
\text { BMI and WC. Prenatal BPA } \\
\text { negatively associated with BMI and } \\
\text { adiposity in girls and positively in } \\
\text { boys. }\end{array}$ & (403) \\
\hline & Phthalates, BPA & Girls in US & $\begin{array}{l}\text { BPA associated with decreased BMI } \\
\text { in 6- 9yr old girls. }\end{array}$ & (428). \\
\hline & $\begin{array}{l}\text { Phthalates, BPA, PCBs, } \\
\text { HCH, HCB, PBDE }\end{array}$ & $\begin{array}{l}\text { Pregnant Spanish birth cohort } \\
\text { study of Environment and } \\
\text { Childhood project. Background } \\
\text { exposure. }\end{array}$ & $\begin{array}{l}\text { BPA not associated with child weight } \\
\text { status. }\end{array}$ & (21) \\
\hline & BPA & $\begin{array}{l}\text { CHAMACOS study in California } \\
\text { birth cohort. Background exposure. }\end{array}$ & $\begin{array}{l}\text { Prenatal urinary BPA inversely } \\
\text { associated with BMI and \%body fat } \\
\text { at } 9 \text { years in girls but not boys. }\end{array}$ & (143) \\
\hline
\end{tabular}

Compr Physiol. Author manuscript; available in PMC 2018 September 12. 


\begin{tabular}{|c|c|c|c|c|c|}
\hline \multirow{7}{*}{ 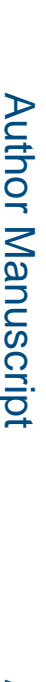 } & Class & Compound(s) Studied & Population & Finding & Reference \\
\hline & & & & $\begin{array}{l}\text { Urinary BPA at } 5 \text { years not } \\
\text { associated with BMI. Urinary BPA at } \\
9 \text { years positively associated with } \\
\text { BMI, body fat, and overweight/ } \\
\text { obesity. }\end{array}$ & \\
\hline & & $\mathrm{BPA}$ & $\begin{array}{l}\text { INMA birth cohort in Spain. } \\
\text { Background exposure. }\end{array}$ & $\begin{array}{l}\text { BPA weakly associated with } \\
\text { increased WC at } 4 \text { years but not } \\
\text { associated with BMI or WC at earlier } \\
\text { ages. }\end{array}$ & $(405)$ \\
\hline & & Phthalates, BPA & Korean girls 6-14yrs old & $\begin{array}{l}\text { Early exposure 6-14yr old females: } \\
\text { urine BPA not associated with } \\
\text { childhood obesity. }\end{array}$ & (77) \\
\hline & & BPA & $\begin{array}{l}\text { Chinese school children 8-15yrs } \\
\text { old. Background exposure. }\end{array}$ & $\begin{array}{l}\text { Early exposure: BPA associated with } \\
\text { BMI in males and females. }\end{array}$ & (417) \\
\hline & & BPA & $\begin{array}{l}\text { 2003-2008 NHANES children } \\
\text { 6-9yrs old }\end{array}$ & $\begin{array}{l}\text { Early Exposure: BPA associated with } \\
\text { obesity and BMI z-score. }\end{array}$ & (394) \\
\hline & & BPA & $\begin{array}{l}\text { Mother-child pairs with or without } \\
\text { occupational BPA exposure }\end{array}$ & $\begin{array}{l}\text { Maternal exposure to BPA in } \\
\text { workplace associated with decreased } \\
\text { birth weight. }\end{array}$ & (269) \\
\hline
\end{tabular}


Table 8

Adult POP Exposure and Associations with Obesity

\begin{tabular}{|c|c|c|c|c|}
\hline Class & Compound(s) Studied & Population & Finding & Reference \\
\hline \multirow[t]{11}{*}{ Organochlorines } & $\begin{array}{l}\text { OC pesticides, PCBS, } \\
\text { PBB, DDE, DDT }\end{array}$ & $\begin{array}{l}\text { CARDIA prospective study in } \\
\text { young adults without diabetes. } \\
\text { Background exposure. }\end{array}$ & $\begin{array}{l}\text { Serum p, p'-DDE, p, p'- DDT, and } \\
\text { some PCB congeners predicted BMI. } \\
\text { Several PCB congeners nonlinearly } \\
\text { associated with increased BMI. } \\
\text { Oxychlordane, trans-nonachlor, HCB, } \\
\beta-\text { HCH, Mirex not associated with } \\
\text { BMI. }\end{array}$ & $(230)$ \\
\hline & $\begin{array}{l}\text { Dioxins, dioxin-like } \\
\text { PCBs, non-dioxin-like } \\
\text { PCBs, DDE, } \beta \text {-HCH, OC } \\
\text { pesticides }\end{array}$ & $\begin{array}{l}\text { NHANES 1999- 2002. Adults } \\
\text { without diabetes. Background } \\
\text { exposure. }\end{array}$ & $\begin{array}{l}\text { PCDD, DDE, } \beta \text {-HCH and PCBs } \\
\text { associated with waist circumferences. } \\
\text { NDL PCB inverted U-shaped } \\
\text { association with WC. }\end{array}$ & $(223)$ \\
\hline & Dioxin, $\mathrm{PCBs}$ & $\begin{array}{l}\text { Cross-sectional study of general } \\
\text { population in Japan with and } \\
\text { without diabetes }\end{array}$ & $\begin{array}{l}\text { Dioxins and PCBs associated with } \\
\text { MS. }\end{array}$ & $(399)$ \\
\hline & $\begin{array}{l}\text { PCDDs, PCDFs, PCBs, } \\
\text { OC pesticides }\end{array}$ & $\begin{array}{l}\text { NHANES 1999- } 2002 \text { adults with } \\
\text { background exposure. }\end{array}$ & $\begin{array}{l}\text { HpCDD, OCDD, and DDE positively } \\
\text { associated with BMI. PCB } 153 \\
\text { negatively associated with BMI. } \\
\text { Oxychlordane, trans- nonachlor not } \\
\text { associated with BMI. }\end{array}$ & $(224)$ \\
\hline & $\begin{array}{l}\mathrm{HCH}, \mathrm{HCB}, \mathrm{OC} \\
\text { pesticides, TCDD, } \\
\text { DDE/DDT }\end{array}$ & $\begin{array}{l}\text { Obese adults undergoing bariatric } \\
\text { surgery in Portugal. Background } \\
\text { exposure. }\end{array}$ & $\begin{array}{l}\text { Adipose methoxychlor associated } \\
\text { with LDL. Adipose methoxychlor and } \\
\text { HCH lindane associated with } \\
\text { Framingham CVD risk score. }\end{array}$ & $(317)$ \\
\hline & PCBs, DDE & Obese adults without diabetes. & $\begin{array}{l}\text { Adipose PCBs and DDE associated } \\
\text { with weight, BMI, WC, and CT-VAT. } \\
\text { Adipose PCBs and DDE associated } \\
\text { with visceral adipose and visceral/ } \\
\text { subcutaneous ratio. }\end{array}$ & $(107)$ \\
\hline & $\begin{array}{l}\mathrm{HCH} \text {, endosulfans, Aldrin, } \\
\text { dieldrin, DDT, DDE }\end{array}$ & $\begin{array}{l}\text { Adults with and without MetS. } \\
\text { Background exposure. }\end{array}$ & $\begin{array}{l}\beta \text {-HCH and Aldrin associated with } \\
\text { MetS. }\end{array}$ & $(391)$ \\
\hline & $\begin{array}{l}\text { PCB, OC pesticides, } \\
\text { dioxin, HCB, DDE, BDE }\end{array}$ & $\begin{array}{l}\text { PIVUS older adults, background } \\
\text { exposure. Cross-sectional and } \\
\text { prospective }\end{array}$ & $\begin{array}{l}\text { Cross sectional: Trans- nonachlor } \\
\text { positively associated with WC in } \\
\text { males, no association in females. } \\
\text { DDE positively associated with WC } \\
\text { in males and females. HCB positively } \\
\text { associated with WC in males but not } \\
\text { in females. OCDD not associated } \\
\text { with WC in males or females. PCB } \\
\text { associations were positive, negative, } \\
\text { or null based on congener and gender. } \\
\text { Prospective: trans- nonachlor not } \\
\text { associated with WC. OCDD } \\
\text { associated with WC in females but } \\
\text { not in males. DDE associated with } \\
\text { WC in males but not in females. PCB } \\
\text { associations were positive, negative, } \\
\text { or null based on congener and gender. }\end{array}$ & $(226)$ \\
\hline & PCBs, OC pesticides & $\begin{array}{l}\text { PIVUS older adults, background } \\
\text { exposure. }\end{array}$ & $\begin{array}{l}\text { Sum of OC pesticides and of less- } \\
\text { chlorinated PCBs were positively } \\
\text { associated with weight gain. Sum of } \\
\text { highly- chlorinated PCBs were } \\
\text { negatively associated with weight } \\
\text { gain. }\end{array}$ & $(241)$ \\
\hline & $\mathrm{PCBs}$ & $\begin{array}{l}\text { Non-obese adults in the } \\
\text { Seguimiento Universidad de } \\
\text { Navarra (SUN) Project }\end{array}$ & $\begin{array}{l}\text { PCBs associated with increased risk } \\
\text { of becoming obese. }\end{array}$ & $(108)$ \\
\hline & $\mathrm{PCB} s, \mathrm{DDE}, \beta-\mathrm{HCH}$ & $\begin{array}{l}\text { Obese and normal weight } \\
\text { individuals in Belgium. Case- } \\
\text { control. Background exposure. }\end{array}$ & $\begin{array}{l}\beta-\mathrm{HCH} \text { positively associated and } \\
\text { NDL PCBs negatively associated with } \\
\text { BMI, WC, fat mass percentage, and }\end{array}$ & $(106)$ \\
\hline
\end{tabular}

Compr Physiol. Author manuscript; available in PMC 2018 September 12. 


\begin{tabular}{|c|c|c|c|c|}
\hline Class & \multirow[t]{2}{*}{ Compound(s) Studied } & \multirow[t]{2}{*}{ Population } & \multirow{2}{*}{$\begin{array}{l}\text { Finding } \\
\text { total adipose tissue. DDE not } \\
\text { associated. }\end{array}$} & \multirow[t]{2}{*}{ Reference } \\
\hline & & & & \\
\hline & $\begin{array}{l}\text { Dioxin, oxychlordane, } \\
\text { trans-nonachlor, DDT }\end{array}$ & $\begin{array}{l}\text { NHANES } 1999-2002 \text { adults. } \\
\text { Cross-sectional. Background } \\
\text { exposure. }\end{array}$ & $\begin{array}{l}\text { DDT positively associated with WC } \\
\text { in females but negatively associated } \\
\text { in males. OC pesticides positively } \\
\text { associated with BMI in males and } \\
\text { negatively associated in females. }\end{array}$ & (110) \\
\hline & $\begin{array}{l}\text { NDL PCB, DL PCB, } \\
\text { HCB, DDE }\end{array}$ & Flemish adults. Background. & $\begin{array}{l}\text { In men and women, NDL PCB } \\
\text { negatively associated with BMI and } \\
\text { HCB positively associated with BMI. } \\
\text { Also in women, DDE and DL PCB } \\
\text { positively associated with BMI. }\end{array}$ & (104) \\
\hline & $\begin{array}{l}\text { PCBs, dioxin, } \mathrm{BDE}, \mathrm{DDE} \text {, } \\
\text { OC pesticides }\end{array}$ & $\begin{array}{l}\text { PIVUS older adults, background } \\
\text { exposure. }\end{array}$ & $\begin{array}{l}\text { OCDD, PCBS } 74,99,105,118, \mathrm{HCB}, \\
\text { and DDE positively associated with } \\
\text { fat mass. PCBs } 156,157,169,170, \\
180,189,194,206, \text { and } 209 \\
\text { negatively associated with fat mass. }\end{array}$ & (332) \\
\hline & PCBs, DDE, HCB & $\begin{array}{l}\text { Adults in highly polluted Eastern } \\
\text { Slovakia. }\end{array}$ & $\begin{array}{l}\text { PCBs, DDE, HCB associated with } \\
\text { BMI. }\end{array}$ & (218) \\
\hline & $\begin{array}{l}\text { PCBs, DDE, HCB, OC } \\
\text { pesticides }\end{array}$ & $\begin{array}{l}\text { PIVUS older adults, background } \\
\text { exposure. }\end{array}$ & $\begin{array}{l}\text { Less chlorinated PCBs }(105,118), \\
\text { DDE, HCB, trans-nonachlor were } \\
\text { positively related to visceral and } \\
\text { subcutaneous adipose tissue (vAT and } \\
\text { scAT). More highly chlorinated PCBs } \\
\text { were negatively associated with vAT } \\
\text { and scAT. PCB } 189 \text { had inverted U- } \\
\text { shaped association with vAT/scAT. }\end{array}$ & \\
\hline & $\begin{array}{l}\text { PCBs, DDE, HCB, } \beta- \\
\text { HCH, trans-nonachlor, } \\
\text { oxychlordane }\end{array}$ & $\begin{array}{l}\text { Cross-sectional study of Swedish } \\
\text { women. Background exposure. }\end{array}$ & $\begin{array}{l}\text { Some DL PCB congeners (PCB-105, } \\
\text { PCB-118), DDE, HCB, and } \beta-H C H \\
\text { positively associated with BMI. NDL } \\
\text { PCBs (PCB-156 and PCB-180) } \\
\text { negatively associated with BMI. OC } \\
\text { pesticides not associated. }\end{array}$ & (128) \\
\hline & $\begin{array}{l}\text { PCBs, } \beta \text {-HCH, DDT, } \\
\text { DDE, HCB, OC pesticides }\end{array}$ & $\begin{array}{l}\text { Canadian males. Cross-sectional. } \\
\text { Background exposure. }\end{array}$ & $\begin{array}{l}\text { Total organochlorines not associated } \\
\text { with BMI. } \beta-\mathrm{HCH} \text {, DDE, and } \\
\text { oxychlordane positively associated } \\
\text { with BMI. PCBs, HCB, mirex, trans- } \\
\text { nonachlor, and oxychlordane not } \\
\text { associated with BMI. }\end{array}$ & (164) \\
\hline & $\begin{array}{l}\text { PCBs, } \beta \text {-HCH, DDT, } \\
\text { DDE, HCB, OC pesticides }\end{array}$ & $\begin{array}{l}\text { Canadian males. Cross-sectional. } \\
\text { Background exposure. }\end{array}$ & $\begin{array}{l}\text { Total organochlorines, NDL PCBs, } \\
\text { DDE, HCB, } \beta \text {-HCH, trans- } \\
\text { nonachlor, oxychlordane positively } \\
\text { associated with BMI. DDT and mirex } \\
\text { not associated with BMI. }\end{array}$ & (312) \\
\hline & $\mathrm{DDE}$ & $\begin{array}{l}\text { African American women in U.S. } \\
\text { Cross-sectional. Background } \\
\text { exposure. }\end{array}$ & $\begin{array}{l}\text { DDE positively associated with BMI } \\
\text { but not waist-hip ratio. }\end{array}$ & (343) \\
\hline \multirow[t]{2}{*}{$\begin{array}{l}\text { Polybrominated } \\
\text { flame retardants } \\
\text { (BFRs) }\end{array}$} & PBBs and PBDEs & $\begin{array}{l}\text { NHANES 2003- } 2004 \text { adults. } \\
\text { Background exposure. }\end{array}$ & $\begin{array}{l}\text { PBB- } 153 \text { nonlinearly associated with } \\
\text { MetS and WC. PBDE- } 153 \text { inverted U } \\
\text { shaped associated with MetS. }\end{array}$ & (239) \\
\hline & PBDEs & $\begin{array}{l}\text { PIN study pregnant women in US. } \\
\text { Background exposure. }\end{array}$ & $\begin{array}{l}\text { Milk levels PBDEs associated with } \\
\text { BMI in female moms. }\end{array}$ & (91) \\
\hline $\begin{array}{l}\text { Polycyclic } \\
\text { Aromatic } \\
\text { Hydrocarbons } \\
\text { (PAHs) }\end{array}$ & PAH metabolites & $\begin{array}{l}\text { NHANES 2001- } 2008 \text { adults. } \\
\text { Background exposure. }\end{array}$ & $\begin{array}{l}\text { Urinary 2-phenanthrene positively } \\
\text { associated with obesity. 1- } \\
\text { naphthalene negatively associated } \\
\text { with obesity. 2-naphthalene, 1- } \\
\text { phenanthrene and 2- phenanthrene } \\
\text { positively associated with 3+ risk } \\
\text { factors for MetS. }\end{array}$ & (324) \\
\hline Phthalate Esters & Phthalates & NHANES 2003- 2008 & $\begin{array}{l}\text { High MW metabolites (MECPP, } \\
\text { MEHHP, MEOHP, MEHP, MBzP, } \\
\text { MCNP, and MCOP) associated with } \\
\text { obesity in male and female adults. }\end{array}$ & (59) \\
\hline
\end{tabular}




\begin{tabular}{|c|c|c|c|c|c|}
\hline \multirow{3}{*}{ 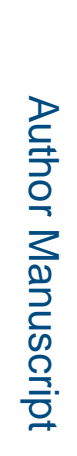 } & Class & Compound(s) Studied & Population & Finding & Reference \\
\hline & & & & $\begin{array}{l}\text { DEHP metabolites associated with } \\
\text { obesity in female adults. DEHP and } \\
\text { high MW metabolites associated with } \\
\text { obesity in males } 60+\text { yrs old. }\end{array}$ & \\
\hline & & Phthalates & $\begin{array}{l}\text { NHANES 1999- } 2002 . \\
\text { Background exposure. }\end{array}$ & $\begin{array}{l}\text { MEP associated with BMI in adult } \\
\text { males and females. MBP inversely } \\
\text { associated with BMI and WC in } \\
\text { elderly, non- significant positive trend } \\
\text { in males but inverse in females. } \\
\text { MBzP positively associated with BMI } \\
\text { and WC in adult males, not associated } \\
\text { in females. MEHP inversely related to } \\
\text { BMI and WC in adult females. } \\
\text { MEHHP associated with adult males, } \\
\text { not associated in females. }\end{array}$ & (145) \\
\hline \multirow{4}{*}{$\begin{array}{l}\frac{D}{\stackrel{D}{T}} \\
\text { 윽 }\end{array}$} & & Phthalates & NHANES 1999-2002 male adults & $\begin{array}{l}\text { MBzP, MEHHP, MEOHP, and MEP } \\
\text { associated with WC. }\end{array}$ & $(370)$ \\
\hline & \multirow{4}{*}{$\begin{array}{l}\text { Bisphenol A } \\
\text { (BPA) and } \\
\text { Bisphenol A } \\
\text { diglycidyl ether } \\
\text { (BADGE) }\end{array}$} & BPA & In CHIANTI Italian adults & BPA associated with WC and weight & (122) \\
\hline & & BPA & NHANES 2003-2006 adults. & $\begin{array}{l}\text { BPA associated with general and } \\
\text { abdominal obesity. }\end{array}$ & $(65)$ \\
\hline & & BPA & $\begin{array}{l}\text { Cross-sectional study in Chinese } \\
\text { adults. }\end{array}$ & $\begin{array}{l}\text { BPA associated with general and } \\
\text { abdominal obesity. }\end{array}$ & $(420)$ \\
\hline$<$ & & BPA & NHANES 2003- 2004 adults. & BPA not associated with BMI. & $(216)$ \\
\hline
\end{tabular}




\section{Table 9}

POP Exposures and Associations with Diabetes

\begin{tabular}{|c|c|c|c|c|}
\hline Class & Compound(s) Studied & Population & Finding & Reference \\
\hline \multirow[t]{12}{*}{ Organochlorines } & $\begin{array}{l}\text { OC pesticides, PCBS, } \\
\text { PBB }\end{array}$ & $\begin{array}{l}\text { CARDIA young adults without } \\
\text { diabetes, age } 27.2+/-3.3 \mathrm{yrs} \\
\text { old, BMI } 29.1+/-6.7 \mathrm{~kg} / \mathrm{m} 2 \text {. } \\
\text { Background exposure. }\end{array}$ & $\begin{array}{l}\text { p,p'-DDE and PCBs predicted HOMA- } \\
\text { IR. }\end{array}$ & (230) \\
\hline & $\begin{array}{l}\text { PCDDs, PCDFs, dioxin- } \\
\text { like PCBs, non- dioxin- } \\
\text { like PCBs, OC pesticides }\end{array}$ & $\begin{array}{l}\text { NHANES 1999-2002. Adults } \\
\text { without diabetes. Background } \\
\text { exposure. }\end{array}$ & $\begin{array}{l}\text { Oxychlordane, trans-nonachlor, PCB170, } \\
\text { PCB187 strongly associated with higher } \\
\text { HOMA-IR. }\end{array}$ & (222) \\
\hline & $\begin{array}{l}\text { PCDDs, PCDFs, dioxin- } \\
\text { like PCBs, non- dioxin- } \\
\text { like PCBs, OC pesticides }\end{array}$ & $\begin{array}{l}\text { NHANES 1999-2002. } \\
\text { Adults without diabetes. } \\
\text { Background exposure. }\end{array}$ & $\begin{array}{l}\text { OC pesticides and PCBs associated with } \\
\text { high fasting glucose }\end{array}$ & (223) \\
\hline & $\begin{array}{l}\text { PCB, OC pesticides, DDE, } \\
\text { Dioxins }\end{array}$ & $\begin{array}{l}\text { NHANES 1999-2002. } \\
\text { Adults with background } \\
\text { exposure. }\end{array}$ & $\begin{array}{l}\text { PCB-153, trans-nonachlor, oxychlordane, } \\
\text { DDE, OCDD and PCDD } 73 \text { strongly } \\
\text { associated with T2D prevalence. TCDD } \\
\text { unrelated to diabetes prevalence. }\end{array}$ & (224) \\
\hline & $\begin{array}{l}\text { PCB, OC pesticides, } \\
\text { dioxin, } \mathrm{HCB}, \mathrm{DDE}, \mathrm{BDE}\end{array}$ & $\begin{array}{l}\text { Prospective Investigation of the } \\
\text { Vasculature in Uppsala Seniors } \\
\text { (PIVUS). Older adults, } \\
\text { background exposure. Cross- } \\
\text { sectional and prospective }\end{array}$ & $\begin{array}{l}\text { PCBs, sum of OC pesticides, and trans- } \\
\text { nonachlor associated with incident T2D. } \\
\text { Dioxin not associated with incident } \\
\text { diabetes. }\end{array}$ & (227) \\
\hline & $\begin{array}{l}\text { PCB, PCDD, PCDF, OC } \\
\text { pesticides }\end{array}$ & $\begin{array}{l}\text { NHANES 1999-2002 } \\
\text { Adults with background } \\
\text { exposure. }\end{array}$ & $\begin{array}{l}\text { Dioxin-like PCBs and OC pesticides } \\
\text { associated with diabetes. } \\
\text { PCDDs and non-dioxin-like PCBs were } \\
\text { not associated with diabetes. } \\
\text { PCDFs were weakly associated with } \\
\text { diabetes. }\end{array}$ & (225). \\
\hline & PCB, HxCDD, DDT & $\begin{array}{l}\text { NHANES 1999-2002. } \\
\text { Adults with background } \\
\text { exposure. }\end{array}$ & $\begin{array}{l}\text { Serum 1, 2, 3, 4, 6, 7, 8-PCDD, PCB } 126 \text {, } \\
\text { DDT levels associated with diabetes. }\end{array}$ & (114) \\
\hline & OC pesticides, DDE, DTT & $\begin{array}{l}\text { HHANES 1982-1984: } \\
\text { Mexican-American Adults with } \\
\text { background exposure. }\end{array}$ & $\begin{array}{l}\text { Serum trans-nonachlor, } \beta \text { - } \\
\text { hexachlorocyclohexane, oxychlordane, } \\
\text { and highest exposure to DDT and DDE } \\
\text { associated diabetes. Trans-nonachlor and } \\
\beta \text { - hexachlorocyclohexane associated with } \\
\text { elevated serum glucose. }\end{array}$ & $(85)$ \\
\hline & $\begin{array}{l}\text { PCB, DDE, OC pesticides, } \\
\text { HCB }\end{array}$ & $\begin{array}{l}\text { Mohawk Nation at Akwesasne } \\
\text { adults }\end{array}$ & $\begin{array}{l}\text { Serum PCB, DDE, HCB associated with } \\
\text { diabetes. Mirex negatively associated with } \\
\text { diabetes. }\end{array}$ & $(80)$ \\
\hline & PCB, DDE, & Great Lakes Consortium for the & DDE and dioxin-like mono-ortho & (398) \\
\hline & PBDE, BDE & $\begin{array}{l}\text { Health Assessment of Great } \\
\text { Lakes Sport Fish Consumption } \\
\text { adults. }\end{array}$ & $\begin{array}{l}\text { PCBs associated with diabetes. Non- } \\
\text { dioxin like PCBs and PBDEs were not } \\
\text { associated with diabetes. }\end{array}$ & \\
\hline & $\begin{array}{l}\text { OC pesticides, } \mathrm{PCBs} \text {, } \\
\text { PDBE, } \mathrm{PBB}\end{array}$ & $\begin{array}{l}\text { CARDIA(Coronary Artery } \\
\text { Risk Development in Young } \\
\text { Adults) } 18-30 y r s \text { old in US } \\
\text { without diabetes. } \\
\text { Prospective study, background } \\
\text { exposure. }\end{array}$ & $\begin{array}{l}\text { Low dose trans-nonachlor, oxychlordane, } \\
\text { mirex, highly chlorinated PCBs, and PBB } \\
153 \text { associated with increased risk } \\
\text { diabetes incidence. }\end{array}$ & (229) \\
\hline
\end{tabular}

Compr Physiol. Author manuscript; available in PMC 2018 September 12. 


\begin{tabular}{|c|c|c|c|c|}
\hline \multirow[t]{7}{*}{ Class } & $\begin{array}{l}\text { Compound(s) Studied } \\
\text { PCBs, DDE }\end{array}$ & $\begin{array}{l}\text { Population } \\
\text { Obese adults without diabetes. } \\
\text { Background exposure. }\end{array}$ & $\begin{array}{l}\text { Finding } \\
\text { Serum PCBs associated with fasting } \\
\text { glucose and abnormal GTT, while } \\
\text { negatively associated with HOMA-B. } \\
\text { Serum PCB180 negative associated with } \\
\text { fasting insulin. Adipose PCBs associated } \\
\text { with HbA1C and fasting glucose. Serum } \\
\text { and adipose DDE associated with glucose } \\
\text { levels during GTT and abnormal GTT. }\end{array}$ & $\begin{array}{c}\text { Reference } \\
\text { (107) }\end{array}$ \\
\hline & $\begin{array}{l}\mathrm{HCH}, \mathrm{HCB}, \mathrm{OC} \\
\text { pesticides, TCDD, } \\
\text { DDE/DDT }\end{array}$ & $\begin{array}{l}\text { Obese adults undergoing } \\
\text { bariatric surgery in Portugal. } \\
\text { Background exposure. }\end{array}$ & $\begin{array}{l}\text { Adipose total POPs associated with } \\
\text { HOMA-IR and dysglycemia. Adipose } \\
\text { methoxychlor associated with glycemia, } \\
\text { HbA1c. Adipose DDE associated with } \\
\text { glucose metabolism and HbA1c. }\end{array}$ & $(317)$ \\
\hline & PCB, DDT, DDE, HCB & $\begin{array}{l}\text { Nurse's Health Study: female } \\
\text { adults in US. Background } \\
\text { exposure. Prospective study }\end{array}$ & $\begin{array}{l}\text { Plasma HCB positively associated with } \\
\text { incident T2D. PCBs not significantly } \\
\text { associated with increased T2D risk. }\end{array}$ & $(429)$ \\
\hline & $\begin{array}{l}\text { Oxychlordane, trans- } \\
\text { nonachlor, p,p'-DDE, PCB } \\
\text { 153, BDE } 153\end{array}$ & $\begin{array}{l}\text { Adults in Finland. Background } \\
\text { exposure. }\end{array}$ & $\begin{array}{l}\text { Oxychlordane, trans-nonachlor, p-p'- } \\
\text { DDE, and PCB } 153 \text { positively associated } \\
\text { with prevalent T2D. }\end{array}$ & (24) \\
\hline & PCB, DDE & $\begin{array}{l}\text { Elderly adults in Faroese } \\
\text { Islands. Background exposure }\end{array}$ & $\begin{array}{l}\text { Elderly adults with T2D had higher PCB } \\
\text { levels. In nondiabetics, increased PCB } \\
\text { levels associated with increased fasting } \\
\text { glucose and decreased fasting insulin. }\end{array}$ & $(132)$ \\
\hline & PCBs, PCDDs, PCDFs & $\begin{array}{l}\text { Healthy adults in Japan. } \\
\text { Background exposure. }\end{array}$ & $\begin{array}{l}\text { Accumulated toxic equivalents (TEQs) of } \\
\text { PCDDs, PCDFs, dioxin-like PCBs, and } \\
\text { total dioxins associated with HbA1c. }\end{array}$ & $(400)$ \\
\hline & $\mathrm{HCB}, \mathrm{DDE}$ & $\begin{array}{l}\text { Swedish fishermen and their } \\
\text { wives. }\end{array}$ & $\begin{array}{l}\text { PCB-153 and p,p'-DDE associated with } \\
\text { diabetes prevalence. }\end{array}$ & $(337)$ \\
\hline \multicolumn{5}{|c|}{ High levels of exposure } \\
\hline & TCDD & $\begin{array}{l}\text { Healthy adults without diabetes } \\
\text { around Superfund site in } \\
\text { Arkansas }\end{array}$ & $\begin{array}{l}\text { TCDD associated with higher plasma } \\
\text { insulin at fasting and } 30,60 \text {, and } 120 \mathrm{~min} \\
\text { during GTT }\end{array}$ & (86) \\
\hline & $\begin{array}{l}\text { PCBs, DDE, OC } \\
\text { pesticides }\end{array}$ & $\begin{array}{l}\text { Anniston Community Health } \\
\text { Survey adults near PCB- } \\
\text { contaminated area. }\end{array}$ & $\begin{array}{l}\text { PCB associated with diabetes. When sex- } \\
\text { stratified, PCBs had a positive association } \\
\text { in women and an inverse association in } \\
\text { men. DDE associated with diabetes } \\
\text { prevalence in women. }\end{array}$ & $(357)$ \\
\hline & $\mathrm{PCB}, \mathrm{PBB}$ & $\begin{array}{l}\text { Michigan PBB cohort exposed } \\
\text { to contaminated food, } \\
\text { prospective study. }\end{array}$ & $\begin{array}{l}\text { PCB associated with increased incidence } \\
\text { of diabetes in women. }\end{array}$ & $(411)$ \\
\hline & PCBs, DDE, HCB & $\begin{array}{l}\text { Adults in highly polluted } \\
\text { Eastern Slovakia. }\end{array}$ & $\begin{array}{l}\text { Circulating PCBs, DDE, HCB correlated } \\
\text { with fasting glucose and seruminsulin. }\end{array}$ & $(218)$ \\
\hline & OC pesticides & $\begin{array}{l}\text { Agricultural Health Study: } \\
\text { pesticide applicators and } \\
\text { spouses in US without diabetes. } \\
\text { Occupational exposure }\end{array}$ & $\begin{array}{l}\text { Having ever used and cumulative use of } \\
\text { aldrin, chlordane, and heptachlor } \\
\text { increased odds of diabetes incidence. }\end{array}$ & $(276)$ \\
\hline & $\begin{array}{l}\text { PCB, DDE, DDT, HCB, } \beta- \\
\mathrm{HCH}\end{array}$ & $\begin{array}{l}\text { PCBRISK cross- sectional } \\
\text { survey of heavily polluted area } \\
\text { of Eastern Slovakia }\end{array}$ & $\begin{array}{l}\text { PCBs, DDE, DDT, HCB, and } \beta-\mathrm{HCH} \\
\text { associated with prediabetes, but only } \\
\text { PCB, DDT, and DDE associated with } \\
\text { diabetes. }\end{array}$ & $(401)$ \\
\hline & TCDD & $\begin{array}{l}\text { US Air Force veterans of } \\
\text { Operation Ranch Hand (Air }\end{array}$ & $\begin{array}{l}\text { Agent Orange associated with higher risk } \\
\text { of glucose abnormalities and T2D. }\end{array}$ & $(150)$ \\
\hline
\end{tabular}

Compr Physiol. Author manuscript; available in PMC 2018 September 12. 


\begin{tabular}{|c|c|c|c|c|}
\hline \multirow[t]{3}{*}{ Class } & Compound(s) Studied & $\begin{array}{l}\text { Population } \\
\text { Force Health Study) from } \\
\text { Vietnam War 1961-1971. } \\
\text { Occupational exposure }\end{array}$ & Finding & Reference \\
\hline & TCDD & $\begin{array}{l}\text { US Air Force veterans of } \\
\text { Operation Ranch Hand (Air } \\
\text { Force Health Study) from } \\
\text { Vietnam War 1961-1971. } \\
\text { Occupational exposure. }\end{array}$ & $\begin{array}{l}\text { Dose-response relationship between } \\
\text { TCDD-contaminated Agent Orange and } \\
\text { T2D in veterans with background levels } \\
\text { of exposure. }\end{array}$ & (247) \\
\hline & TCDD & $\begin{array}{l}\text { Residents surrounding Seveso, } \\
\text { Italy, industrial accident. }\end{array}$ & $\begin{array}{l}\text { Residents living in medium-exposure } \\
\text { areas to TCDD had higher T2D mortality } \\
\text { as compared to high-exposure areas. }\end{array}$ & $(43)$ \\
\hline \multicolumn{5}{|c|}{ Maternal/PrenatalExposure } \\
\hline & PCB and DDE & $\begin{array}{l}\text { Swedish mothers and their } \\
\text { children. Background exposure. }\end{array}$ & $\begin{array}{l}\text { Nonsignificant trend of maternal exposure } \\
\text { to PCB-135 or DDE and decreased T1D } \\
\text { development in the offspring. }\end{array}$ & (326) \\
\hline & PCBs & $\begin{array}{l}\text { Collaborative Perinatal Project } \\
(\mathrm{CPP}): \text { mothers with and } \\
\text { without diabetes and their } \\
\text { children }\end{array}$ & $\begin{array}{l}\text { Maternal exposure to PCBs monotonically } \\
\text { associated with T1D in offspring. }\end{array}$ & (246) \\
\hline & $\begin{array}{l}\text { DDE, PCB, } \mathrm{HCB}, \mathrm{HCH}, \\
\text { Organophospha te } \\
\text { pesticides }\end{array}$ & $\begin{array}{l}\text { PELAGIE cohort of pregnant } \\
\text { women in Brittany }\end{array}$ & $\begin{array}{l}\text { Prenatal exposure to DDE was associated } \\
\text { with a decrease in insulin in girls but not } \\
\text { boys. Prenatal exposure PCB } 153 \text { was } \\
\text { associated with decreased insulin. }\end{array}$ & $(100)$ \\
\hline & PCBs, DDE, HCB & $\begin{array}{l}\text { Adults frompolluted area of } \\
\text { Slovakia whose mothers } \\
\text { experienced high level s of } \\
\text { exposure. }\end{array}$ & $\begin{array}{l}\text { Maternal exposure to PCBs associated } \\
\text { with impaired fasting glucose. }\end{array}$ & (217) \\
\hline \multirow[t]{6}{*}{$\begin{array}{l}\text { Polybrominated } \\
\text { flame retardants } \\
\text { (BFRs) }\end{array}$} & PBBs and PBDEs & $\begin{array}{l}\text { NHANES } 2003-2004 \text {, adults, } \\
\text { BMI } 28.3+/-5.9 \mathrm{~kg} / \mathrm{m} 2\end{array}$ & $\begin{array}{l}\text { PBB- } 153 \text { and PBDE- } 153 \text { positively } \\
\text { associated with prevalent diabetes. } \\
\text { PBB-153 associated with glycemia. } \\
\text { PBDE-99 and PBDE- } 100 \text { nonsignificant } \\
\text { positive association with diabetes. } \\
\text { PBDE- } 28 \text { and }-47 \text { not associated with } \\
\text { diabetes. }\end{array}$ & (239) \\
\hline & PCB, DDE, PBDE, BDE & $\begin{array}{l}\text { Great Lakes Consortium for the } \\
\text { Health Assessment of Great } \\
\text { Lakes Sport Fish Consumption } \\
\text { adults. }\end{array}$ & PBDEs not associated with diabetes. & (398) \\
\hline & $\begin{array}{l}\text { OC pesticides, PCBs, } \\
\text { PDBE, PBB }\end{array}$ & $\begin{array}{l}\text { CARDIA(Coronary Artery } \\
\text { Risk Development in Young } \\
\text { Adults) } 18-30 y \text { olds in US } \\
\text { without diabetes. Prospective } \\
\text { study, background exposure. }\end{array}$ & $\begin{array}{l}\text { Low dose PBB } 153 \text { associated with } \\
\text { increased risk of diabetes incidence. }\end{array}$ & (229) \\
\hline & $\begin{array}{l}\text { PCB, OC pesticides, } \\
\text { dioxin, } \mathrm{HCB}, \mathrm{DDE}, \mathrm{BDE}\end{array}$ & $\begin{array}{l}\text { Prospective Investigation of the } \\
\text { Vasculature in Uppsala Seniors } \\
\text { (PIVUS). Older adults, } \\
\text { background exposure. Cross- } \\
\text { sectional and prospective }\end{array}$ & $\begin{array}{l}\text { BDE not associated with } \mathrm{T} 2 \mathrm{D} \text { prevalence } \\
\text { or risk of } \mathrm{T} 2 \mathrm{D} \text { incidence. }\end{array}$ & (227) \\
\hline & PCB, PBB & $\begin{array}{l}\text { Michigan PBB cohort exposed } \\
\text { to contaminated food, } \\
\text { prospective study. }\end{array}$ & $\begin{array}{l}\text { PBB not a risk factor for diabetes } \\
\text { incidence. }\end{array}$ & (411) \\
\hline & $\begin{array}{l}\text { Oxychlordane, trans- } \\
\text { nonachlor, p,p'-DDE, PCB } \\
\text { 153, BDE 47, BDE } 153\end{array}$ & $\begin{array}{l}\text { Adults in Finland. Background } \\
\text { exposure. }\end{array}$ & $\begin{array}{l}\text { BDE } 47 \text { and BDE } 153 \text { not associated with } \\
\text { T2D. }\end{array}$ & (24) \\
\hline
\end{tabular}




\begin{tabular}{|c|c|c|c|c|}
\hline Class & Compound(s) Studied & Population & Finding & Reference \\
\hline \multirow{3}{*}{$\begin{array}{l}\text { Polycyclic } \\
\text { Aromatic } \\
\text { Hydrocarbons } \\
\text { (PAHs) }\end{array}$} & PAHs & $\begin{array}{l}\text { NHANES merged 2001-2006. } \\
\text { Adults, background exposure. }\end{array}$ & $\begin{array}{l}\text { Urinary PAH biomarkers positively } \\
\text { associated with diabetes. } 0\end{array}$ & $(28)$ \\
\hline & PAHs & $\begin{array}{l}\text { Chinese adults, background } \\
\text { exposure. }\end{array}$ & $\begin{array}{l}\text { Urinary PAH metabolites had dose- } \\
\text { response association to increased risk of } \\
\text { diabetes. }\end{array}$ & $(432)$ \\
\hline & 8 PAH metabolites & $\begin{array}{l}\text { NHANES 2001-2008 adults. } \\
\text { Background exposure. }\end{array}$ & $\begin{array}{l}\text { 1-naphthalene, 2-naphthalene, 2- } \\
\text { phenanthrene and 1-pyrene associated } \\
\text { with T2D. }\end{array}$ & (324) \\
\hline \multirow[t]{6}{*}{ Phthalate Esters } & $\begin{array}{l}\text { BPA and phthalate } \\
\text { metabolites }\end{array}$ & $\begin{array}{l}\text { Nurses' Health Study (NHS) } \\
\text { and NHSII female adults. } \\
\text { Background exposure. }\end{array}$ & $\begin{array}{l}\text { In NHSII- urine butyl phthalates (MBP } \\
\text { and MiBP) and total phthalate metabolites } \\
\text { positively associated with incident T2D. } \\
\text { In older NHS cohort, no significant } \\
\text { association between phthalates and } \\
\text { incident T2D. }\end{array}$ & (376) \\
\hline & Phthalates & $\begin{array}{l}\text { NHANES 2001-2008 adults } \\
\text { without diabetes. Background } \\
\text { exposure. }\end{array}$ & $\begin{array}{l}\text { Urinary MnBP, MiBP, MCPP, and DEHP } \\
\text { (sum of MEHP, MEHHP, MEOHP) } \\
\text { positively associated with fasting blood } \\
\text { glucose, fasting insulin, and HOMA-IR }\end{array}$ & (163) \\
\hline & Phthalates & ElderlyKorean adults. & $\begin{array}{l}\text { Sum of DEHP metabolites (sum of } \\
\text { MEHHP and MEOHP) associated with } \\
\text { HOMA. No association between MnBP } \\
\text { and HOMA. }\end{array}$ & (199) \\
\hline & Phthalates and BPA & $\begin{array}{l}\text { NHANES 2003-2008 } \\
\text { adolescents (12-19yrs old). } \\
\text { Background exposure. }\end{array}$ & $\begin{array}{l}\text { DEHP metabolites (MEHP, MECPP, } \\
\text { MEHHP, and MEOHP) associated with } \\
\text { HOMA-IR and insulin resistance. Lower } \\
\text { molecular weight phthalates (MEP, MBP, } \\
\text { MiBP, MBP) (found in cosmetics and } \\
\text { personal use items) not associated with } \\
\text { HOMA- IR or insulin resistance. }\end{array}$ & (395) \\
\hline & Phthalates & $\begin{array}{l}\text { Healthy Mexican women. } \\
\text { Background exposure. }\end{array}$ & $\begin{array}{l}\text { Higher levels of DEHP, MEHHP, } \\
\text { MEOHP, and MECPP are positively } \\
\text { associated with diabetes. MBzP } \\
\text { negatively associated with diabetes. }\end{array}$ & (378) \\
\hline & Phthalates & NHANES 1999-2002 & $\begin{array}{l}\text { MBP, MBzP, and MEP associated with } \\
\text { increased HOMA, but only MBzP and } \\
\text { MEP remained significant after } \\
\text { adjustment for renal and hepatic function. }\end{array}$ & (370) \\
\hline \multirow[t]{5}{*}{$\begin{array}{l}\text { Bisphenol A and } \\
\text { Bisphenol A } \\
\text { diglycidyl ether } \\
\text { (BADGE) }\end{array}$} & BPA & $\begin{array}{l}\text { National Health Examination } \\
\text { Survey of Thai adults. } \\
\text { Background exposure. }\end{array}$ & $\begin{array}{l}\text { Serum BPA positively associated with } \\
\text { diabetes and impaired fasting glucose. }\end{array}$ & $(20)$ \\
\hline & BPA & $\begin{array}{l}\text { Adults in Iran. Background } \\
\text { exposure. }\end{array}$ & $\begin{array}{l}\text { Urine BPA positively associated with } \\
\text { diabetes prevalence and HbA1c. }\end{array}$ & (23) \\
\hline & BPA & $\begin{array}{l}\text { Adults in Korea. Background } \\
\text { exposure. }\end{array}$ & $\begin{array}{l}\text { Urine BPA not significantly associated } \\
\text { with T2D. }\end{array}$ & (201) \\
\hline & BPA & $\begin{array}{l}\text { NHANES 2003-2008 adults. } \\
\text { Background exposure. }\end{array}$ & $\begin{array}{l}\text { Urine BPA positively associated with } \\
\text { diabetes. }\end{array}$ & (349) \\
\hline & $\begin{array}{l}\text { BPA and phthalate } \\
\text { metabolites }\end{array}$ & $\begin{array}{l}\text { Nurses' Health Study (NHS) } \\
\text { and NHSII female adults. } \\
\text { Background exposure. }\end{array}$ & $\begin{array}{l}\text { In NHSII- urine BPA positively associated } \\
\text { with incident T2D. In older NHS cohort, } \\
\text { no significant associations between BPA } \\
\text { and incident T2D. }\end{array}$ & (376) \\
\hline
\end{tabular}




\begin{tabular}{|l|l|l|l|c|}
\hline Class & Compound(s) Studied & Population & Finding & Reference \\
\cline { 2 - 5 } & BPA & NHANES 2003-2004 adults. & $\begin{array}{l}\text { BPA associated with diabetes (adjusted } \\
\text { for BMI, WC). }\end{array}$ & (216) \\
\hline BPA & NHANES 2005-2006 adults. & $\begin{array}{l}\text { BPA associated with diabetes, but } \\
\text { association lost in fully adjusted models } \\
\text { (age, sex, race, education, income, } \\
\text { smoking, BMI, WC, urinary creatinine). }\end{array}$ & (263) \\
\hline
\end{tabular}

Williamson, JR, Lacy, PE. Structural aspects of adipose tissue: A summary attempting to synthesize the information contained in the preceding chapters. Compr Physiol 2011, Supplement 15: Handbook of Physiology, Adipose Tissue: 201-210. First published in print 1965. doi: 10.1002/ cphy.cp050120

Jeanrenaud, B. Lipid components of adipose tissue. Compr Physiol 2011, Supplement 15: Handbook of Physiology, Adipose Tissue: 169-176. First published in print 1965. doi: 10.1002/cphy.cp050115

Napolitano, L. The fine structure of adipose tissues. Compr Physiol 2011, Supplement 15: Handbook of Physiology, Adipose Tissue: 109-124. First published in print 1965. doi: 10.1002/cphy.cp050112

Chalmers, TM. Lipid-mobilizing activity during fasting. Compr Physiol 2011, Supplement 15: Handbook of Physiology, Adipose Tissue: 549-555. First published in print 1965. doi: 10.1002/cphy.cp050156

Street, JC, Sharma, RP. Accumulation and Release of Chemicals by Adipose Tissue. Compr Physiol 2011, Supplement 26: Handbook of Physiology, Reactions to Environmental Agents: 483-493. First published in print 1977. doi: 10.1002/cphy.cp090130

Scow, RO. Perfusion of isolated adipose tissue: FFA release and blood flow in rat parametrial fat body. Compr Physiol 2011, Supplement 15: Handbook of Physiology, Adipose Tissue: 437-453. First published in print 1965. doi: 10.1002/cphy.cp050145 